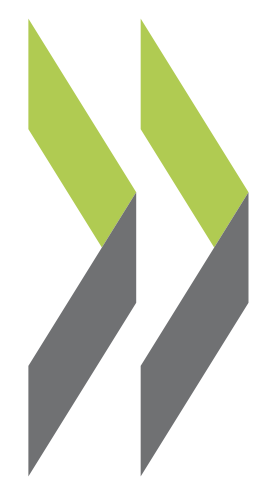

OECD Economics Department Working Papers No. 1311

The short-term impact of product market reforms: A cross-country firm-level

\title{
Peter Gal,
} analysis 
Organisation de Coopération et de Développement Économiques

Organisation for Economic Co-operation and Development

21-Jul-2016

ECONOMICS DEPARTMENT

English - Or. English

Cancels \& replaces the same document of 01 July 2016

THE SHORT-TERM IMPACT OF PRODUCT MARKET REFORMS:

A CROSS-COUNTRY FIRM-LEVEL ANALYSIS

ECONOMICS DEPARTMENT WORKING PAPERS No. 1311

By Peter Gal and Alexander Hijzen

OECD Working Papers should not be reported as representing the official views of the OECD or of its member countries. The opinions expressed and arguments employed are those of the author(s).

Authorised for publication by Christian Kastrop, Director, Policy Studies Branch, Economics Department.

All Economics Department Working Papers are available at www.oecd.org/eco/workingpapers

JT03399428

Complete document available on OLIS in its original format

This document and any map included herein are without prejudice to the status of or sovereignty over any territory, to the delimitation of international frontiers and boundaries and to the name of any territory, city or area. 
OECD Working Papers should not be reported as representing the official views of the OECD or of its member countries. The opinions expressed and arguments employed are those of the author(s).

Working Papers describe preliminary results or research in progress by the author(s) and are published to stimulate discussion on a broad range of issues on which the OECD works.

Comments on Working Papers are welcomed, and may be sent to OECD Economics Department, 2 rue André-Pascal, 75775 Paris Cedex 16, France, or by e-mail to eco.contact@oecd.org.

All Economics Department Working Papers are available at www.oecd.org/eco/workingpapers.

This document and any map included herein are without prejudice to the status of or sovereignty over any territory, to the delimitation of international frontiers and boundaries and to the name of any territory, city or area.

The statistical data for Israel are supplied by and under the responsibility of the relevant Israeli authorities. The use of such data by the OECD is without prejudice to the status of the Golan Heights, East Jerusalem and Israeli settlements in the West Bank under the terms of international law.

Latvia was not an OECD member at the time of preparation of this paper. Accordingly, Latvia is not included in the list of OECD countries and is not included in the area totals.

\section{(c) OECD (2016)}

You can copy, download or print OECD content for your own use, and you can include excerpts from OECD publications, databases and multimedia products in your own documents, presentations, blogs, websites and teaching materials, provided that suitable acknowledgment of OECD as source and copyright owner is given. All requests for commercial use and translation rights should be submitted to rights@oecd.org 


\section{ABSTRACT/RÉSUMÉ \\ The short-term impact of product market reforms: A cross-country firm-level analysis}

This paper analyses the effects of product market reforms in the short and medium term across 10 regulated industries and 18 advanced economies for the period 1998-2013 using internationally comparable firm-level data based on Orbis. It provides four key insights. First, product market reforms have positive effects on capital, output and employment and their effects increase over time. After two years, they raise capital by $4 \%$, output by $3 \%$ and employment by $1.5 \%$. Second, differences in production technology and the nature of product market regulations across sectors generate important differences in the mechanisms through which reforms operate. In network industries, reforms tend to benefit small firms, while the opposite is observed in retail trade. Product market reforms also promote firm entry, particularly those that reduce entry barriers. Third, credit constraints can play an important role in weakening the positive impact of product market reform on investment. Fourth, product market reforms also tend to have positive effects on firms in downstream sectors - both at home and abroad - that make intensive use of intermediate inputs from deregulated sectors.

JEL Classification Numbers: D04; D22; L43; L51; L8; L9

Keywords: structural reform, competition, credit constraints, firm entry, Orbis

$* * * * * * * * * * * * * * * * * * * *$

\section{L'incidence à court terme des réformes des marchés de produits- une analyse au niveau des entreprises de plusieurs pays}

Le présent document analyse les effets à court et moyen terme des réformes pratiquées sur les marchés de produits de dix secteurs réglementés dans dix-huit économies avancées sur la période de 1998 à 2013, à partir de données d'entreprises comparables au niveau international issues de la base Orbis. Cette analyse livre quatre grands enseignements. Premièrement, les réformes des marchés de produits ont, sur le capital, la production et l'emploi, des effets positifs qui s'accroissent avec le temps. Après deux ans, l'augmentation constatée est ainsi de $4 \%$ pour le capital, $3 \%$ pour la production et $1.5 \%$ pour l'emploi. Deuxièmement, les différences dans les technologies de production et la nature de la réglementation des marchés de produits d'un secteur à l'autre engendrent d'importantes disparités dans les mécanismes par lesquels les réformes opèrent. Ainsi, dans les industries de réseau, les réformes ont tendance à profiter surtout aux petites entreprises, à l'inverse de ce que l'on observe dans le commerce de détail. Les réformes des marchés de produits favorisent aussi l'entrée d'entreprises sur le marché, en particulier lorsqu'elles ont pour effet de réduire les obstacles à l'entrée. Troisièmement, les restrictions du crédit peuvent jouer un rôle important en affaiblissant l'effet positif des réformes sur l'investissement. Enfin, quatrièmement, les réformes des marchés de produits tendent à avoir des effets positifs sur les entreprises des secteurs d'aval tant nationaux qu'étrangers - faisant un usage intensif de ressources intermédiaires en provenance de secteurs déréglementés.

Codes JEL : D04; D22; L43; L51; L8; L9

Mots clefs : réformes structurelles, compétition, restrictions du crédit, entrée d'entreprises sur le marché, Orbis 


\section{TABLE OF CONTENTS}

THE SHORT-TERM IMPACT OF PRODUCT MARKET REFORMS: A CROSS-COUNTRY FIRM-

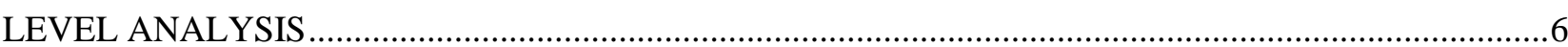

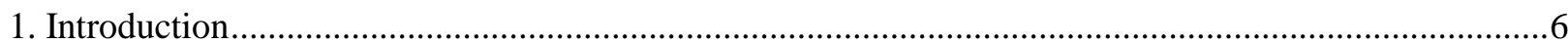

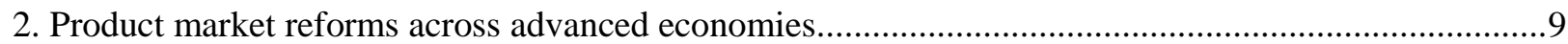

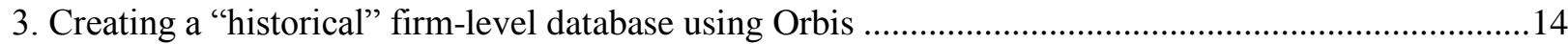

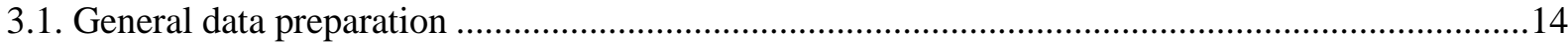

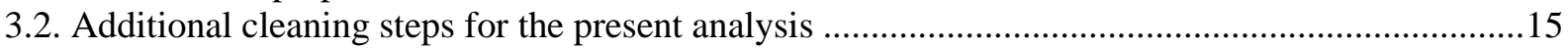

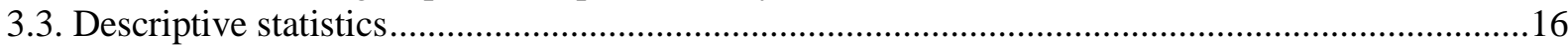

4. The short-term effects of product market reforms in network industries, retail and professional

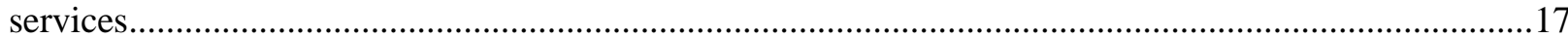

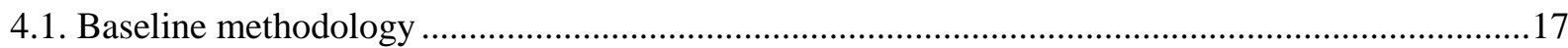

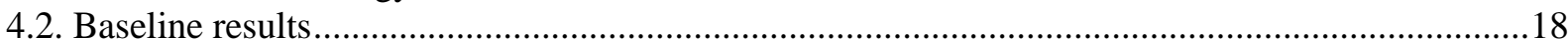

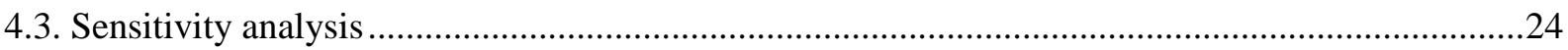

5. The heterogeneous effects of product market reforms across firms and sectors ................................26

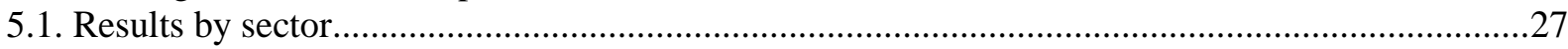

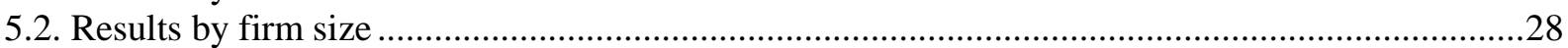

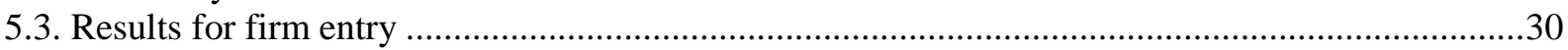

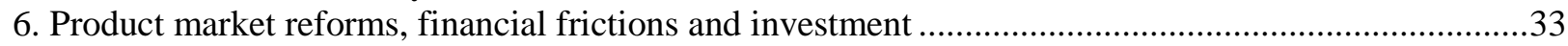

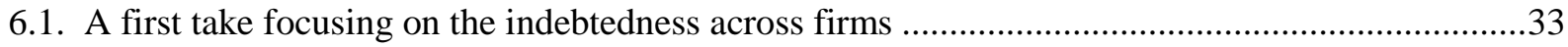

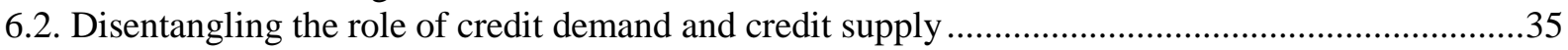

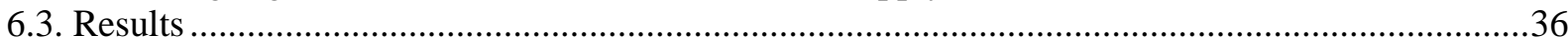

7. The indirect effects of product market reforms through input-output linkages .....................................38

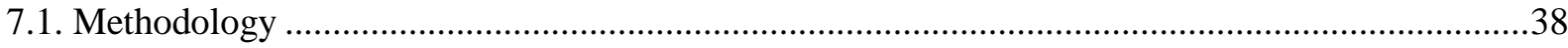

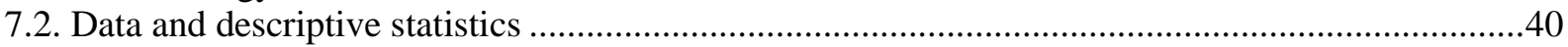

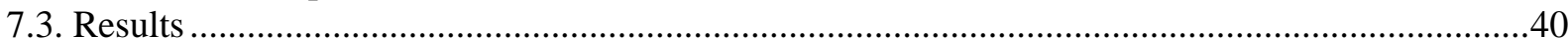

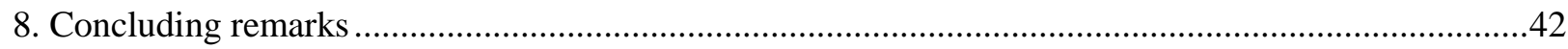

ANNEX A1. CONSTRUCTING ANNUAL INDICATORS ON THE RESTRICTIVENESS OF PRODUCT MARKET REGULATIONS FOR RETAIL AND PROFESSIONAL SERVICES ..................43

ANNEX A2. THE FIRM-LEVEL DATABASE BASED ON ORBIS …......................................................46

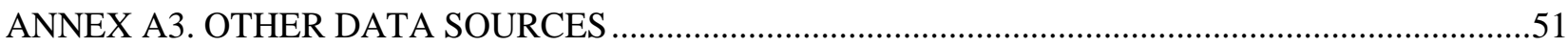

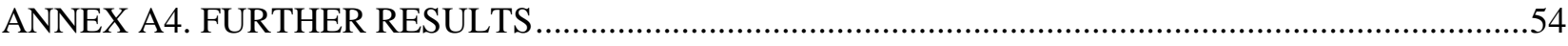

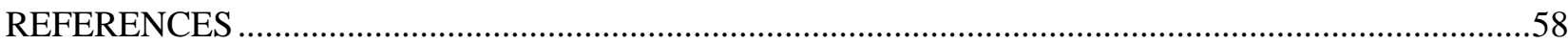

\section{Tables}

Table 1. Number of observations used in the direct effect analysis.......................................................16

Table 2. Descriptive statistics on selected firm-level variables by industry ..........................................17

Table 3a. The effects of a reduction in the overall restrictiveness of product market regulation ..............20

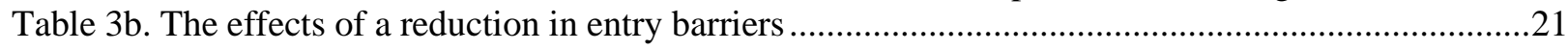

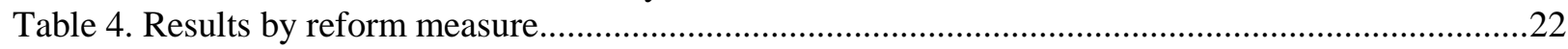

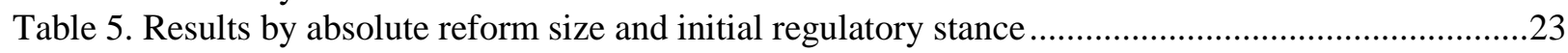

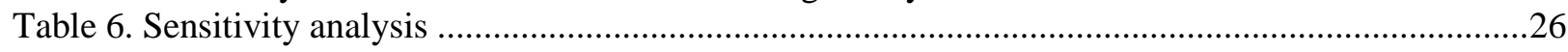

Table 7. The short-term effects of product market reforms by industry ..................................................2 
Table 8. The short-term effects of product market reforms by industry and firm size .............................30

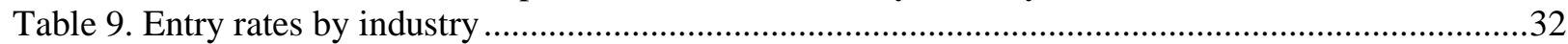

Table 10. The short-term effects of product market reforms on firm entry ….........................................33

Table 11. The short-term effects of product market reforms on investment by industry and debt category 35

Table 12. The role of aggregate credit conditions and external financial dependence for the impact of

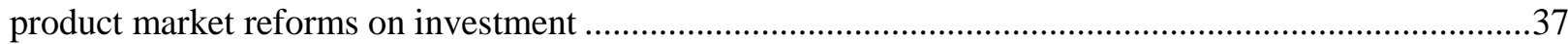

Table 13. The effects of product market reforms in upstream industries on downstream firms................41

Table A1. Keywords for string search in each sector and policy domain...............................................43

Table A2. Constructing annual indicators for retail and professional services.......................................44

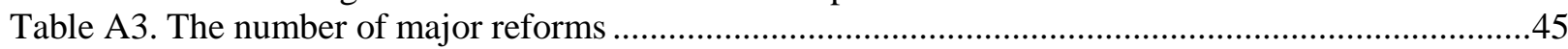

Table A4. Sample statistics by country, sector and year.....................................................................50

Table A5. Employment coverage in Orbis by PMR sectors and size classes 2010 ..............................51

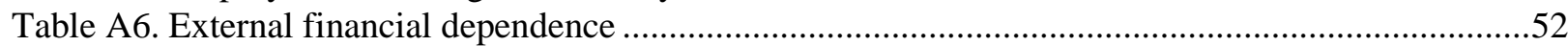

Table A7. The importance of PMR sectors as suppliers of intermediate inputs to other sectors...............53

Table A8. First-stage of instrumental variable regressions selected coefficients .....................................54

Table A9. The short-term effects of product market reforms by industry and firm size ..........................55

Table A10. The short-term effects of product market reforms by industry and firm age ........................56

Table A11. The short-term effects of product market reforms by industry and firm age .........................57

\section{Figures}

Figure 1. The OECD indicators on the restrictiveness of product market regulations .............................10

Figure 2. The restrictiveness of product market regulations over time, 1998-2013 ..............................12

Figure 3. Number of major product market reforms, 1998 - 2013 …....................................................13

Figure 4. The short-term effects of product market reforms on incumbent firms ..................................19

Figure 5. The short-term effects of product market reforms on incumbent firms ...................................29

Figure 6. The role of indebtedness for the short-term effects of product market reforms on investment..34 


\title{
THE SHORT-TERM IMPACT OF PRODUCT MARKET REFORMS: A CROSS-COUNTRY FIRM-LEVEL ANALYSIS
}

\author{
Peter Gal and Alexander Hijzen ${ }^{1}$
}

\section{Introduction}

Given the secular decline in productivity growth and the weakness of the economic recovery in many advanced economies, increased attention is being paid to the potential role of structural reforms for restoring economic growth. While the weak economic recovery reflects in part a problem of aggregate demand, the global financial crisis also had a tendency to undermine aggregate supply, notably through its impact on investment. Moreover, the current economic situation should be seen in the context of the secular slowdown in productivity growth that started well before the beginning of the global financial crisis which suggests that deeper structural forces are also at play (Dabla-Norris et al., 2015; IMF, 2015; OECD, 2015a). ${ }^{2}$ The hope is that structural reforms can promote potential output, while at the same time giving a boost to aggregate demand by raising consumer and business confidence.

While structural reforms can take many forms (e.g. banking supervision, property right laws and employment-protection rules), product market reforms feature particularly prominently on the agenda of many advanced economies (OECD, 2015b). There are at least two reasons for this. First, the long-term benefits of product market reforms are well established and considered relatively high (see Boeri et al., 2015, and Nicoletti and Scarpetta, 2005, for surveys) ${ }^{3}$. Second, there is substantial scope for further product market reform. During the past 15 years, most reform activity has tended to be concentrated in network industries (energy, transport and communication) which used to be heavily regulated in most advanced economies. However, there remains room for further action in specific network industries and countries. Moreover, attention is increasingly shifting to other regulated sectors, most notably, retail trade and professional services.

Although the long-term benefits of product market reforms are well established, much less is known about their effects in the short-term and how they are distributed across workers and firms. Theoretical analyses by Blanchard and Giavazzi (2003), Cacciatore and Fiori (2016) and Cacciatore et al. (2016a, 2016b) suggest that the positive effects of product market reforms only materialise gradually and may even involve some short-term costs. Recent empirical studies provide some evidence for these predictions by showing that the benefits of such reforms tend to materialise only over time, but yield somewhat conflicting insights with respect to the possible presence of short-term costs (e.g. Bassanini,

1. Alexander Hijzen is a Senior Economist in the Directorate for Employment, Labour and Social Affairs of the OECD and a Research Fellow at Institute for the Study of Labour (IZA). Peter Gal is an Economist in the Economics Department of the OECD. This work was conducted when Hijzen and Gal were visiting the Research Department of the International Monetary Fund (IMF). The authors are grateful to the IMF for its hospitality. They would further like to thank Andrea Bassanini, Federico Cingano, Romain Duval, Davide Furceri, Eric Gould, Sebnem Kalemli-Ozcan, Sevcan Yesiltas and participants of seminars at the IMF and the OECD for very helpful comments and suggestions. The authors gratefully acknowledge Tom Baskind, Lauren Canino and Matt Gauthier from Bureau van Dijk for their help with the Orbis data. The views expressed in this paper are those of the authors and cannot be attributed to the OECD, the IMF or their member states. Any remaining errors are their own.

2. Combined with the prolonged weakness in aggregate demand and the repercussions of the financial crisis, this phenomenon has also become known as "secular stagnation" (Summers, 2014).

3. See Egert and Gal (2016), for recent evidence at the macroeconomic level. 
2015; Bordon et al., 2016; Bouis, Duval and Eugster, 2016; IMF, 2016; OECD, 2016). ${ }^{4}$ Moreover, since these studies are conducted at the macro or sector level they do not provide evidence on the allocation of costs and benefits between different firms and workers. Consequently, important questions remain both with respect to the dynamic and distributive effects of product market reforms. Understanding how the effects of product market reforms come about, however, is crucial not only for understanding what role they can play in the current context, but also for shedding light on the political economy of these reforms and the potential need for complementary policies to mitigate their costs or enhance their effectiveness.

This paper contributes to the emerging literature on the short-term effects of product market reforms by providing a comprehensive analysis using internationally comparable firm-level data based on Orbis. It focuses on 10 regulated industries in three broad sectors (network industries, retail trade and professional services) across 18 advanced economies during the period 1998-2013. These sectors feature prominently on the deregulation agenda and exhibit significant differences in their product technology and the nature of regulations. Together they account for about a quarter of non-farm private sector employment. Their economic significance is likely to be even larger as their outputs tend to be widely used as inputs elsewhere in the economy. The main value of firm-level data in the present context is that they allow analysing the effects of reforms in more detail than has been the case so far by comparing their effects across different firms and sectors, thereby providing insights into the mechanisms through which reforms operate. ${ }^{5}$ While a number of previous studies have employed firm-level data to analyse the effects of product market reforms, they tend to focus on a single sector and do not explicitly examine short-term effects (e.g. Bertrand and Kramarz, 2002, for retail in France; Schivardi and Viviano, 2011, for retail in France, Italy, and the United States; Lanau and Topolova, 2016, for network industries, retail and professional services in Italy; Fabrizio et al., 2010, and Goolsbee and Syverson, 2008, for respectively electricity and airlines in the United States).

In order to document the short-term effects of product market reforms, we estimate impulseresponse functions of employment, capital and output to major reforms using the local projection method (Jordà, 2005; Teulings and Zubanov, 2014). Since the main value of using firm-level analysis in the present context is to shed light on the way firms behave in response to product market reforms, the analysis in this paper focuses on the typical firm by employing unweighted regressions. This means that one should be careful making inferences about the macro-economic implications of the results featured in the present analysis. ${ }^{6}$ Furthermore, the core analysis is restricted to incumbent firms that remain in business in the years following a reform. Since product market reforms have potentially important implications for firm entry and exit, an effort is also made to estimate their effects for firm entry. ${ }^{7}$

The key findings from the paper are:

- The short-term effects of product market reforms are positive and strengthen over time. The effects are immediate for both output and investment, and increase to $4 \%$ and $3 \%$ respectively after two years. The effects for employment are considerably smaller and only materialise after

4. For a recent summary of the literature on these issues, see OECD (2016a).

5. The use of firm-level data also enables analysing product market reforms in more detail than in sectoral studies by exploiting the variation in product market regulations across more disaggregated network industries.

6. Unweighted firm-level estimations capture the typical response among the firms in the data whereas sector or country level studies capture the size-weighted response based on the population of firms.

7. Unfortunately, the present dataset does not allow analysing exit with the same level of confidence (see the discussion in Section 5.3). 
two years. ${ }^{8}$ These results control for key firm characteristics, reforms in the two preceding or subsequent years, and many unobserved factors through a rich dummy structure that controls for country-industry specific trends, sector-specific technological developments and country-specific macro-economic conditions. The latter is particularly important since product market reforms often take place when economic conditions are weak. Moreover, the results are robust to the measurement of major reforms and a number of other sensitivity checks.

- There are systematic and plausible differences in the effects of reforms across firms of different size across the different industries. More specifically, in network industries, small firms tend to benefit most from pro-competitive product market reforms, while larger ones downsize to reduce costs and maintain market share. By contrast, in retail trade, large and potentially more efficient businesses tend to be benefit more from such reforms. These qualitative differences in the impact of deregulation between network industries and retail trade highlight important differences in the underlying mechanisms that bring about the positive effects of product market reforms due to differences in production technology, such as for example the degree of capital intensity, and the nature of product market regulations. Moreover, there is also evidence that reforms are associated with increased firm entry in the two sectors.

- Credit constraints weaken the short-term impact of product market reforms on investment. The main challenge of identifying the role of credit constraints is to control for the confounding role of credit demand, i.e. the possibility that firms demand less credit because they face worse investment opportunities. In order to disentangle the role of credit supply from that of credit demand, this paper builds on Rajan and Zingales (1998) by analysing how the impact of product market reforms depends on the need of external funds to finance investment in periods when credit supply is severely constrained versus in periods when it is not. We find that credit constraints can indeed reduce the impact of product market reforms on investment. ${ }^{9}$ This highlights the importance of addressing the problem of weak bank balance sheets when considering product market reforms, and points to the complementary role of financial sector reform more generally.

- Deregulation yields positive spillovers on firms in downstream industries - both domestically and abroad - through input-output linkages. This is consistent with sector-level results by Barrone and Cingano (2011), Bourles et al. (2013) and OECD (2016), but extends the literature in two directions. First, it employs a stronger identification strategy based on the use of intermediate inputs by individual firms in combination with sectoral information on input-output linkages and,

8. The short-term effects of product market deregulation appear to materialise more quickly than is found in sectoral studies of network industries (Bassanini, 2015; Bouis et al., 2016; OECD, 2016). In part, this may reflect the emphasis in the present analysis on the typical firm, which tends to be relatively small. In Section 5.2, it is shown that the benefits of product market reforms are stronger and materialise more quickly for small firms in network industries, while the effects for larger firms may be negative in the short-term, at least for employment. This is consistent with the findings by Bassanini (2015) and OECD (2016). Another factor may be related to the fact that our results do not take account of entry and exit. To the extent that entry takes time, and exit dominates in the short term this provides another explanation for the more positive effects in the short term found here. The medium-term effects are quantitatively similar to those reported in Bouis et al. (2016).

9. Previous studies have either looked at the impact product market reforms on investment or the role of debt using firm-level data. Giroud and Mueller (2015) find that high debt leverage increased the responsiveness The present paper contains qualitatively similar findings even if these are not the prime focus of the analysis. 
in addition, features a much richer set of fixed effects. ${ }^{10}$ Second, it focuses not only on backward linkages between domestic firms but also between firms in different countries. The findings confirm the positive effect of product market reforms on downstream firms through backward linkages within the same country, but also provide some indication that these effects also extend to firms abroad.

This paper also makes a few contributions on the data side. The first is to construct annual indicators of product market regulations in retail and professional services. While indicators on de jure product market regulations for network industries are available at an annual frequency from the OECD, similar indicators for retail trade and professional services are available only every five years and, hence, do not allow identifying the timing of reforms and analysing their short-term effects. Annual indicators for retail trade and professional services are constructed by complementing the OECD indicators with external information on the timing of reforms. The second contribution is to construct a historical firm-level dataset by combining three different vintages of Orbis $(2005,2010,2015) .{ }^{11}$ The construction of a historical dataset is an important part of our analysis since the standard Orbis data as provided by Bureau van Dijk only contains a limited time horizon (typically 5 to 10 years) and, hence, greatly limits the number of reform episodes that can be considered as well as the ability to follow firms through extended periods of time. The resulting historical dataset provides high and relatively stable coverage for the period 1998-2013. It therefore captures at least part of the wave of product market deregulation that took place from the early 1990 s to the early 2000s.

The remainder of this paper is structured as follows. Section 2 discusses how product market reforms are measured and documents their distribution over time and across industries. Section 3 provides details on the construction of the firm-level dataset based on Orbis. Section 4 discusses the baseline methodology, the baseline results and their sensitivity to different specifications. Section 5 analyses the mechanisms through which product market reforms operate by comparing the effects on different types of firms (size and age), as well as the response of firm entry to reforms in each of three broad sectors considered in this paper. Section 6 analyses the role of credit constraints for the short-term impact of product market reforms on investment. Section 7 analyses the indirect effects of product market reforms through backward linkages in the same country as well as abroad. Finally, Section 8 concludes.

\section{Product market reforms across advanced economies}

Sectoral indicators on the restrictiveness of product market regulations are provided by the OECD (Koske et al., 2015). The OECD's database on product market regulations is based on a detailed questionnaire sent out to governments every five years. To give an indication of the degree of detail, the 2013 questionnaire includes around 1400 questions on economy-wide and sector-specific provisions. The indicators are based on rules and regulations and hence capture de jure policy settings. The objective nature of the indicators allows making meaningful comparisons across countries. A drawback of focusing on de jure policy settings is that the indicators do not take account of differences in implementation and enforcement across countries. This means that not all reforms considered in this paper are fully implemented and strictly enforced in practice. The indicators range from 0 to 6 with higher values reflecting more restrictive product market regulations.

In principle, sectoral indicators are available for 7 network industries (which can be classified into three broad groups: energy, transport and communication), the retail sector and 4 professional services

10. Gorodnichenko et al. (2015) emphasize the importance of reliable variation at the firm-level since identifying spillovers using sectoral variation from input-output tables tends to be difficult in practice.

11. In doing so, it builds on previous work by Kalemli-Ozcan et al. (2015). 
sectors (accounting, legal, engineering and architecture) (see Figure 1). Together these sectors account for about a quarter of non-farm private sector employment for the average country in our sample in 2010. However, their economic significance is broader since most of their output is heavily used as inputs in production elsewhere in the economy (Table A6, Annex A3). Regulation in network industries is mainly about the organisation of network access to potential service providers. Regulation in retail trade typically takes the form of entry barriers, specific restrictions for large firms and the flexibility of shops in terms of opening hours and prices. Regulation in professional services relates to barriers to entry and the way services are delivered and includes, amongst others, rules governing the recognition of qualifications and the determination of fees and prices.

\section{Figure 1. The OECD indicators on the restrictiveness of product market regulations}

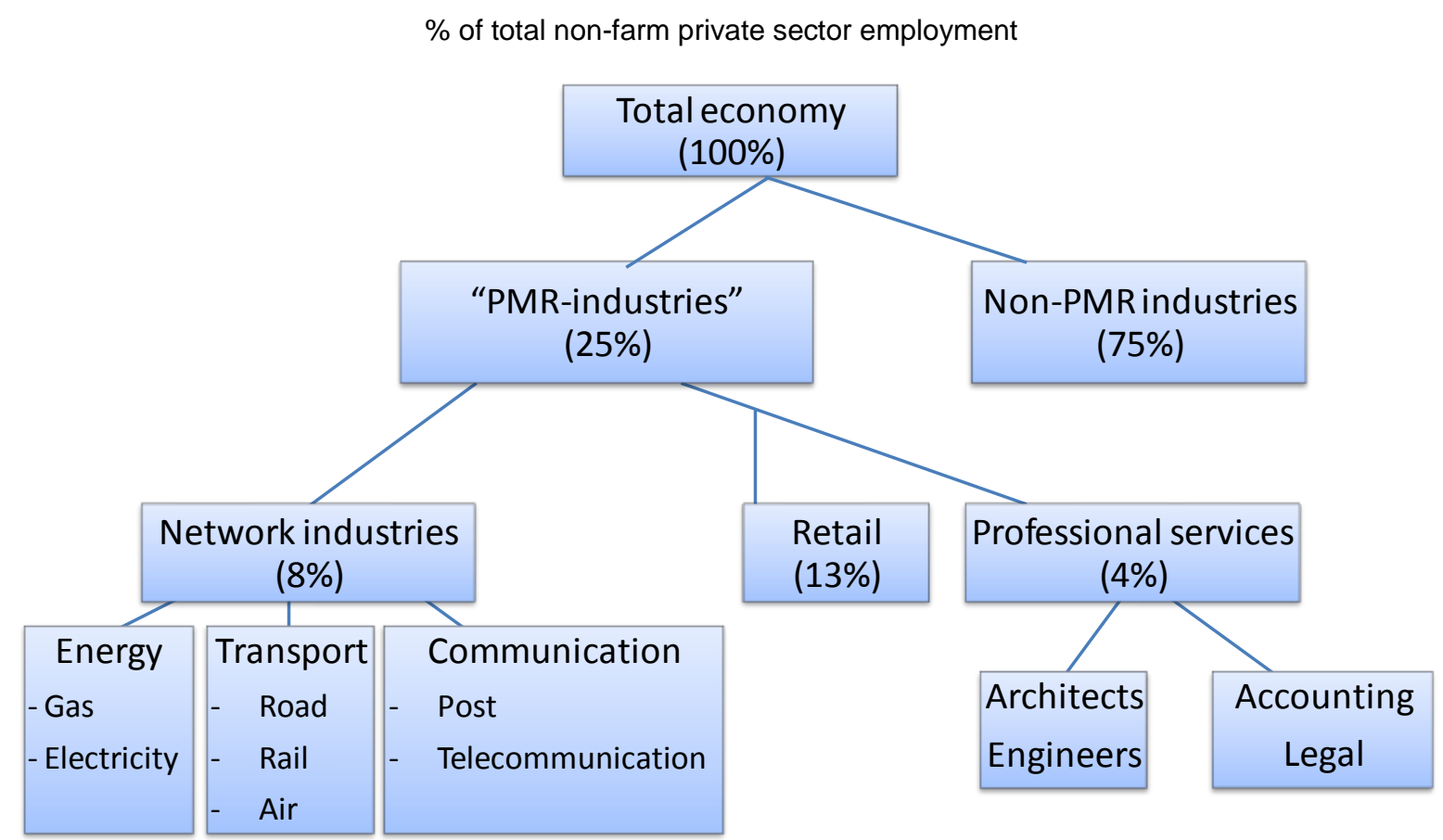

Source: OECD Structural Demographics and Business Statistics for 2010. Unweighted average across 18 OECD countries (see Table 1).

An important limitation of the OECD indicators in the present context is that they are available on an annual basis only for network industries and only every five years for retail and professional services. ${ }^{12}$ This means that the timing of product market reforms in retail and professional services cannot be precisely identified. Consequently, previous studies that have made use of the OECD indicators to analyse the short-term effects of product market reforms have restricted the analysis to a relatively small segment of the economy for which annual indicators are available by concentrating on network industries (Bassanini, 2015; Bouis et al, 2016) or have focused on economy-wide indicators of product market regulations (Bouis et al. 2012; Bordon et al., 2016).

12. An annual indicator for network industries is constructed by the OECD by complementing information from the questionnaire that is sent out every five years with data from publicly available sources. In that sense, the approach used here to construct annual series for retail and professional services is similar to that used by the OECD for network industries. 
In order to allow analysing the short-term effects of product market reforms not only in network industries, but also in retail trade and professional services, this paper constructs annual series indicators on the restrictiveness of product market regulation in those sectors. This is done by combining the OECD indicator values for retail trade and professional services, available at five-year intervals, with detailed information on reforms collected by the IMF on structural reforms, drawing on comprehensive raw information from all historical OECD Economic Surveys for 26 advanced economies (Duval et al., 2016a). Using this information on the timing of reforms, the OECD sub-indicators for retail and professional services are filled up for the intermediate years by an automated procedure based on a string-search algorithm for each major component of product market regulation within these sectors. ${ }^{13}$ If there was only one reform within the five-year interval the indicator was held constant at its latest value until the year of the reform and changed to its next value from the year of the reform onwards. If there were several reforms within the five-year window it was assumed that the quantitative impact of each reform on the PMR indicator for that sector was the same. For a detailed description, see Annex A1.

Apart from extending the focus from network industries to retail and professional services, the use of firm-level data in the present paper allows analysing the role of product market reforms in each of the seven network industries by exploiting the detailed industrial-activity information available in Orbis. In contrast, previous studies that rely on sectoral data could not utilise the full detail in the OECD indicators and were only be able to use the policy variation across three or four broad network industries. Since the nature of rules and regulations with respect to the different categories of professional services tends to be relatively similar, the four professional services sectors were regrouped into two categories: i) business services, consisting of respectively accounting and legal services, and ii) technical services, consisting of respectively engineering and architecture services. As a result, the policy variation for each country will rely on 10 separate industries ( 7 in network industries, 1 in retail, and 2 in professional services).

Figure 2 documents how the restrictiveness of product market regulation evolved from 1998 to 2013. More specifically, it shows the evolution of the extended indicator on the restrictiveness of product market regulations by broad sector in terms of the median country, as well as its dispersion as measured by $25^{\text {th }}$ and the $75^{\text {th }}$ percentiles and the minimum and the maximum. The figure provides a number of insights. First, the median restrictiveness of product market regulations has declined significantly in network industries, fallen modestly in retail and remained largely stable in professional services. Second, the dispersion in the restrictiveness of product market regulations across countries was relatively low in network industries and has declined further, while it is much higher in retail and professional services and has declined only modestly. This indicates that in some countries there remains significant scope for further reforms in retail trade and professional services.

The econometric analysis focuses mainly on major product market reforms with respect to the overall restrictiveness of product market regulation as well as that with respect to entry barriers only. ${ }^{14}$ There are two main arguments for this. First, previous evidence suggests that reforms need to be sufficiently large to have a detectable impact (Alesina et al., 2005). Second, it is likely to yield more robust results because it reduces their sensitivity to measurement error.

A major pro-competitive reform is defined as a large reduction in the indicator of product market regulation while an anti-competitive reform is defined as an increase in the regulatory stance of at least the same size. We consider three alternative criteria to identify major reforms. The first defines major reforms as a change in the PMR indicator of at least 0.5 . This corresponds to almost the 5\% largest annual changes in the PMR indicator regulation across all 10 sectors (R1). While this rule ensures that only major reforms

13. This also allows us to separately consider the impact of reforms with respect to the overall restrictiveness of product market regulation in each sector and with respect to entry barriers only.

14. The extended OECD indicators will be used as a sensitivity check. 
Figure 2. The restrictiveness of product market regulations over time, 1998-2013

Panel A. Network industries

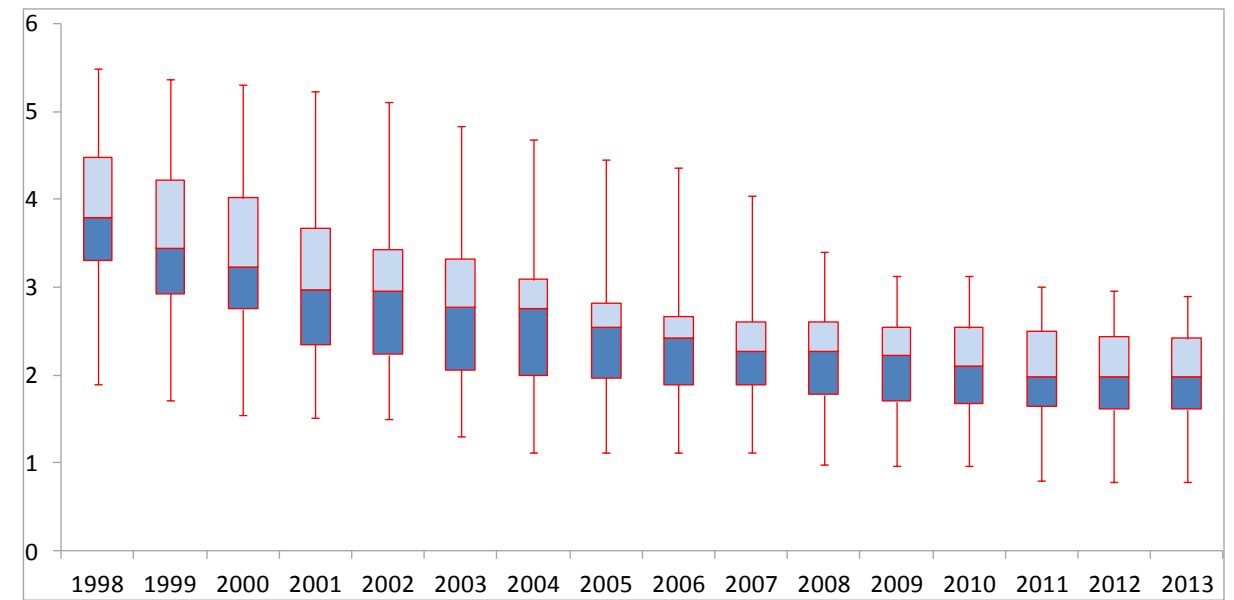

Panel B. Retail trade

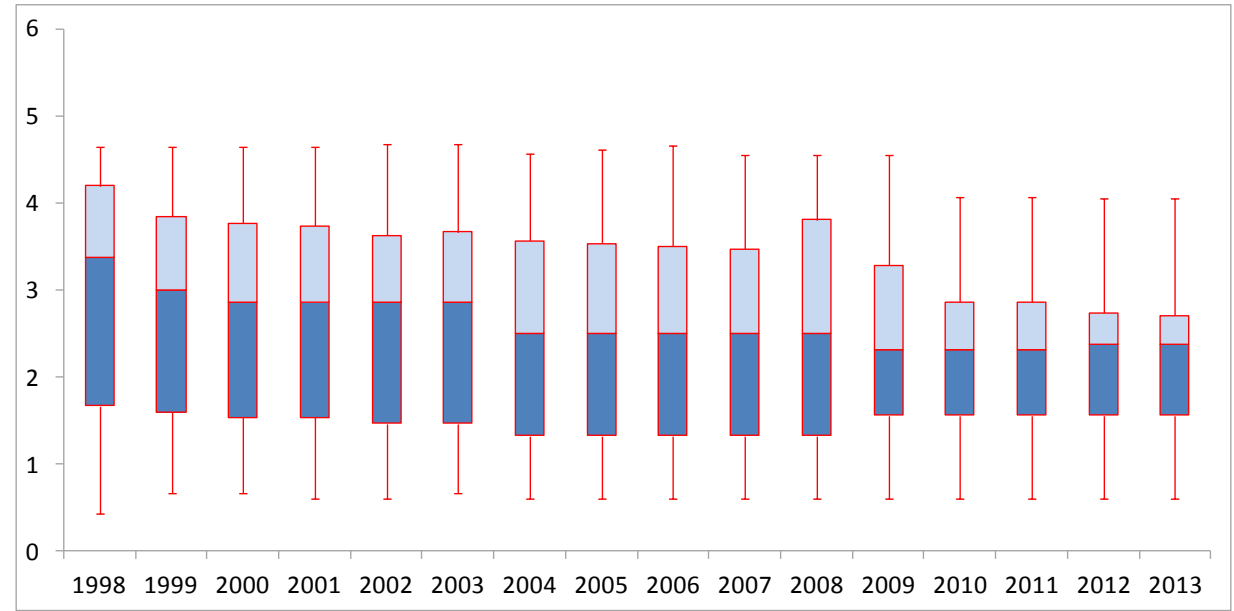

Panel C. Professional services

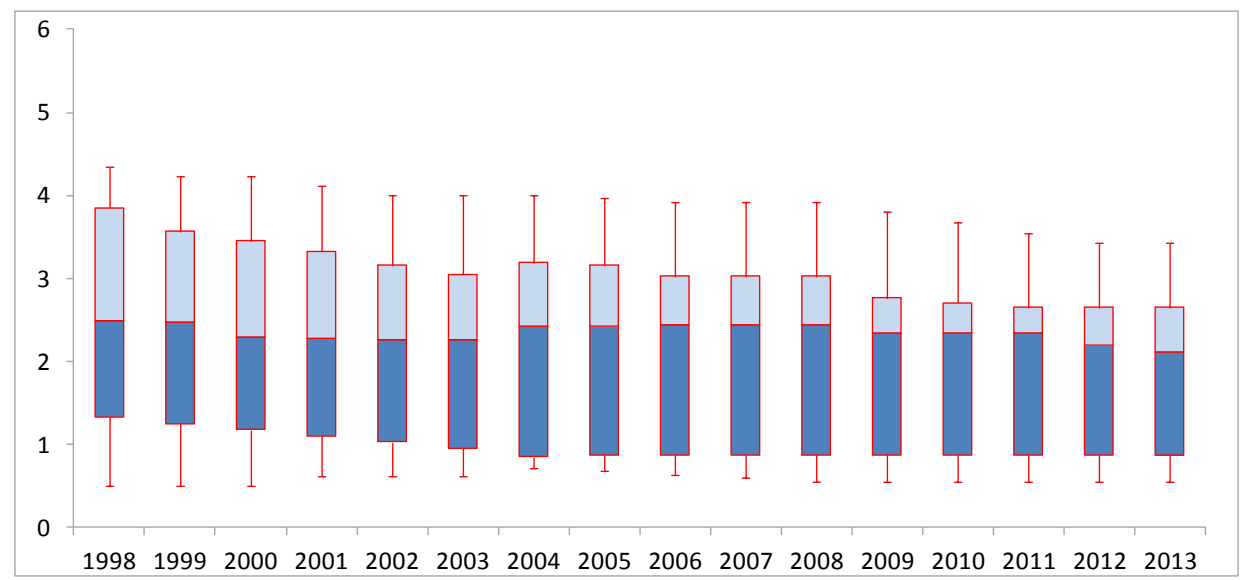

Note: The horizontal line in the boxes represents the median, the upper and lower edges of each boxes reflect the $25^{\text {th }}$ and $75^{\text {th }}$ percentiles and the markers on the extremes denote the maximum and the minimum across countries.

Source: Authors' calculations based on OECD indicators on product market regulation. 
are taken into account it also implies that the number of reforms can vary widely across sectors. In order to ensure that the number of reforms is similar across sectors one may also concentrate on the top 5\% in each sector. However, since the number of major reforms in professional services is relatively limited this means that also relatively small changes in the PMR indicator are classified as major reform changes. To address this issue, we use the highest of either the top $5 \%$ or a 0.5 change in the indicator of product market regulation (R2). Finally, we make use of indicators of major product market reforms developed by Duval et al. (2016a) for network industries in combination with R1 for retail and professional services (R3). The former are based on a narrative approach that makes use of qualitative information about the significance of the reform as well as changes in the OECD indicator. ${ }^{15}$

Figure 3 shows the number of major reforms, in either direction, with respect to the overall restrictiveness of product market regulation for each sector during the period 1998-2013. In order to ensure a meaningful comparison across sectors, the definition of major reforms in terms of the absolute threshold is used (R1). This shows that major reforms were most common in the network industries, and particularly in telecoms and electricity, while they were least common in road transport, retail trade and professional services. ${ }^{16}$ The relatively low number of major reforms in retail and professional services in part reflects the relatively low reform activity in those sectors, consistent with Figure 2, but also the possibility that not all major reforms were identified. Table A3 in Annex A1 reports the number of reforms in each sector for each reform measure.

Figure 3. Number of major product market reforms, 1998 - 2013

Based on absolute changes in the PMR indicator larger than 0.5

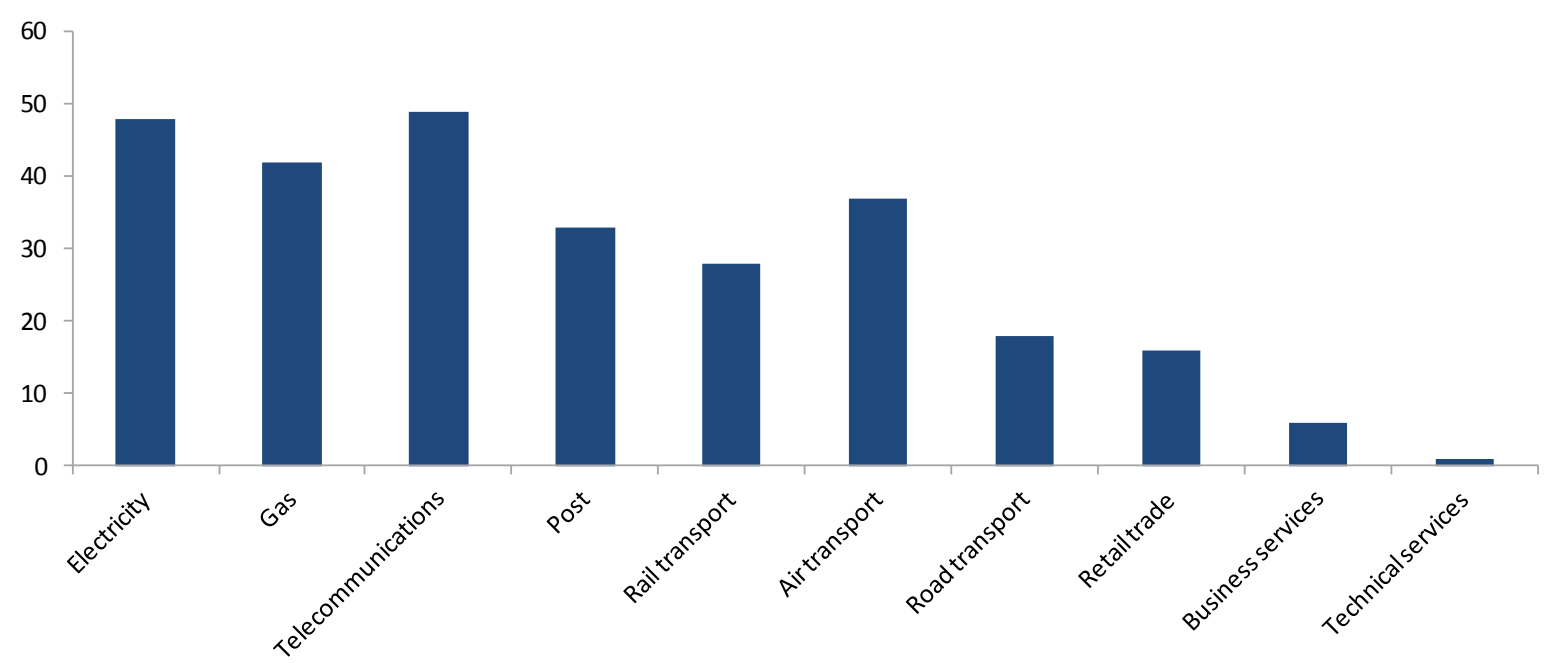

In order to analyse the effects of product market deregulation on downstream firms in other industries, indirect reform measures are constructed. They measure the exposure of firms in downstream sectors to product market reforms in upstream network industries. This is done, for each downstream industry, by weighting major reforms in upstream industries by the share of intermediate inputs from the

15. Public ownership, one component of the indicator for network industries, is taken out from the calculation of this reform measure as this is not directly related to the regulatory practices in the private sector.

16. In the case of road transport, this reflects the fact that in most countries deregulation took place before 1998. 
network industry in question by total intermediate input use in the spirit of Conway and Nicoletti (2006). See Section 7 for details.

\section{Creating a "historical" firm-level database using Orbis}

In order to analyse the short-term effects of product market reforms we combine the indicators on product market reforms with firm-level data on economic outcomes from Orbis. Orbis is a firm-level dataset of companies worldwide provided by Bureau van Dijk, a private company. It contains information on the productive activities and financial conditions of firms based on balance sheets and income statements. While Orbis in principle has global coverage, country coverage is restricted here to advanced economies, for which we have historical information on the restrictiveness of product market regulations and a reasonable coverage in Orbis.

\subsection{General data preparation}

In order to prepare Orbis for analysis the following steps were taken: ${ }^{17}$ (i) constructing a "historical" dataset by combining different vintages of Orbis; (ii) ensuring comparability of monetary variables across countries and over time (PPP conversion and deflation); (iii) constructing a number of key variables which are widely used in empirical work; and (iv) keeping company accounts with valid information. The next sub-section then presents further steps that are aimed at filtering out observations that are not suitable for the present analysis.

A historical dataset is created in order to extend the time horizon in the standard version of Orbis, which is a maximum of 5-10 years depending on the country, but considerably shorter for the majority of firms. ${ }^{18}$ This is done by combining three different vintages of Orbis (2005, 2010 and 2015). To implement the merge across vintages, correspondence tables provided by Bureau van Dijk between the old and new company identifiers (BvD ID-s) are used. As will be shown below, this results in good and relatively stable coverage for the period 1998 to $2013 .{ }^{19}$

To ensure the comparability of monetary variables (revenues, assets, etc.) across countries, the currencies have to be harmonised. ${ }^{20}$ Industry-level deflators are obtained from the OECD STAN database (version ISIC4) and applied - with based year 2005 - after converting the data in national currency. Country-industry level purchasing power parities (PPPs) are applied, for the same reference year, to arrive at internationally comparable values, using the database of Inklaar and Timmer (2014). This ensures that firms in less advanced economies do not appear to be less productive in international comparisons simply because the price level is lower. For details on the procedure, see Annex A2.

The following additional variables are constructed for use in the empirical analysis. ${ }^{21} \mathrm{~A}$ measure of real capital stock constructed by, first, deriving the real value of gross investment flows by deflating the

17. Within the IMF, this is referred to as the RES Orbis Dataset. The data preparation steps closely follows those described in Gal (2013) and also builds on Kalemli-Ozcan et al. (2015) and Ribeiro et al. (2010).

18. This greatly reduces the number of reforms that can be covered in the analysis and limits the ability of estimating impulse response functions over the medium term.

19. There is an approximately 2-year reporting lag. For instance, for the latest, 2015 vintage, most companies do not have more recent data than 2013, although there are some exceptions. See also Kalemli-Ozcan et al (2015).

20. This is mainly important for descriptive statistics across countries. For the regression analysis, this is less relevant since this controls for country-year fixed effects.

21. In addition, we also construct three variants of multi-factor productivity: two types based on production function estimations (OLS and Wooldridge, 2009) and one type using the index number approach and 
difference in the book value of net capital stocks (fixed tangible assets) and depreciation between two years and, subsequently, applying the perpetual inventory method (PIM) to gross investment flows using the book value of fixed tangible assets as the starting value to generate real net capital stocks. Labour productivity is calculated as value added divided by the number of employees. The age of firms is derived as the difference between the current year and the year of incorporation.

Only company accounts are kept that satisfy each of the following criteria: i) refer to the entire calendar year, thereby excluding reports that pertain to only part of the year; ii) are either unconsolidated, consolidated but without unconsolidated counterpart or whose consolidation status is unknown; ${ }^{22}$ iii) contain non-missing and strictly positive values for employment and gross output (measured in terms of operating revenues). The resulting sample corresponds to about 30 million observations for 18 countries for the years 1998-2013 (Table A4 of the annex).

In order to get an indication of the actual coverage of the database, we compare the sample with the universe of companies using official statistical sources from the Structural Demographics and Business Statistics of the OECD (SDBS) on the number of employees. The Structural Demographics and Business Statistics of the OECD (SDBS) contains information on the number of enterprises, establishments, employees by country $*$ industry $*$ employment size class cells, for each year. The underlying sources of the information are national administrative databases which cover the universe of firms - typically business registers. As such, the SDBS can be used to assess the degree of coverage in Orbis by comparing the number of firms in the data with the population of companies. ${ }^{23}$ Table A5 in the annex shows that coverage in terms of employment is close to complete among large firms and in network industries (80$100 \%)$, while other sectors, populated by smaller firms, tend to have lower coverage (20-40\%).

\subsection{Additional cleaning steps for the present analysis}

In addition to the preparatory steps described above which may be deemed useful for any analysis based on Orbis, we apply a number of cleaning rules which are more directly relevant for the present analysis. First, in order to reduce noise from micro and self-employed units, the sample keeps only those company accounts that report at least three employees. Second, since our methodology focuses on growth rates, implausibly high changes in employment, capital stock and output are filtered out. In particular, they are set to missing when their growth rates are related to large level shifts (larger than 100fold increase or smaller than 1/100-fold decrease). In addition, the same variables are also set to missing if they are related to more than 50-fold changes that are reversed the next year ("spikes"). Finally, only firms with at least four consecutive observations with valid information are retained.

After implementing these cleaning rules, the sample used for the analysis of the direct effects of product market reforms consists of about 1 million observations across the 10 PMR industries, 18 OECD countries and the period 1998-2013 (Table 1). The sample for the analysis of the indirect effects of product market reforms that covers entire market economy - defined for the present purposes as the non-farm, nonfinancial business sector $^{24}$ - consists of over 5 million observations sector (Table A4 in the annex). ${ }^{25}$

assuming constant returns to scale (see Annex A2 for details). However, these measured ate not used for the analysis here.

22. This is a compromise that seeks to achieve high coverage without double-counting the activities of firms.

23. In principle, it can also be used to construct weights to correct for the potential underrepresentation of certain types of firms. However, this is not pursued here as the main interest in this paper is in understanding the mechanisms through which the effects of product market reforms operate.

24. More precisely, industries 5-82 in NACE Rev. 2 with the exception of 64-66. 
Note that the unbalanced nature of the data along the sector and the country dimension does not necessarily mean that the identified impact of the reforms will largely be driven by the largest sectors in our analysis. As Angrist and Pischke (2009, Chapter 3.3) explain, if there are heterogeneities in the effects across groups (in our case, sectors and countries), then the estimated overall effect is a weighted average. But the weights are not the sizes of these groups but to the variations in the treatment variable (in our case, reform intensity) across these groups.

Table 1. Number of observations used in the direct effect analysis

By PMR sector, country and year

\begin{tabular}{|c|c|c|c|c|c|c|c|c|}
\hline Sector & $\begin{array}{l}\text { Original } \\
\text { sample }\end{array}$ & $\begin{array}{l}\text { Filtered } \\
\text { sample }\end{array}$ & Country & $\begin{array}{l}\text { Original } \\
\text { sample }\end{array}$ & $\begin{array}{l}\text { Filtered } \\
\text { sample }\end{array}$ & Year & $\begin{array}{l}\text { Original } \\
\text { sample }\end{array}$ & $\begin{array}{l}\text { Filtered } \\
\text { sample }\end{array}$ \\
\hline Electricity & 50,349 & 7,848 & $\overline{A U T}$ & 34,958 & 4,859 & 1998 & 144,677 & 12,246 \\
\hline Gas & 11,212 & 2,137 & BEL & 77,686 & 12,151 & 1999 & 190,067 & 19,092 \\
\hline Telecom & 56,180 & 8,061 & CZK & 203,841 & 72,776 & 2000 & 221,851 & 28,910 \\
\hline Post & 23,485 & 4,176 & DEU & 539,778 & 133,777 & 2001 & 252,243 & 52,087 \\
\hline Rail & 4,528 & 708 & DNK & 21,525 & 3,256 & 2002 & 277,428 & 70,876 \\
\hline Airlines & 11,059 & 1,741 & EST & 91,602 & 19,593 & 2003 & 281,546 & 72,380 \\
\hline Road & 717,350 & 159,100 & ESP & $1,104,160$ & 263,655 & 2004 & 283,695 & 65,808 \\
\hline Retail & $2,871,329$ & 660,680 & FIN & 112,789 & 22,174 & 2005 & 278,413 & 52,948 \\
\hline Accounting \& Legal & 502,295 & 108,553 & FRA & 871,194 & 172,077 & 2006 & 346,558 & 56,129 \\
\hline \multirow[t]{2}{*}{ Architect \& Engineer } & 660,295 & 107,750 & GBR & 77,967 & 9,198 & 2007 & 357,555 & 65,445 \\
\hline & & & GRC & 27,930 & 14,779 & 2008 & 376,640 & 73,824 \\
\hline \multirow[t]{8}{*}{ Total } & $4,908,082$ & $1,060,754$ & ITA & 365,353 & 39,014 & 2009 & 390,771 & 94,900 \\
\hline & & & JPN & 209,292 & 43,785 & 2010 & 395,360 & 90,877 \\
\hline & & & KOR & 43,206 & 4,970 & 2011 & 419,236 & 97,781 \\
\hline & & & PRT & 418,726 & 73,091 & 2012 & 372,496 & 98,612 \\
\hline & & & SWE & 565,839 & 151,190 & 2013 & 319,546 & 108,839 \\
\hline & & & SVN & 46,434 & 3,960 & & & \\
\hline & & & SVK & 95,802 & 16,449 & Total & $4,908,082$ & $1,060,754$ \\
\hline & & & Total & $4,908,082$ & $1,060,754$ & & & \\
\hline
\end{tabular}

\subsection{Descriptive statistics}

The three main sectors considered in this paper (network, retail and professional services) differ importantly in terms of their average firm characteristics (Table 2). Firm in network industries tend to be relatively large and capital-intensive, in line with the presence of strong technological entry barriers that increase optimal firm size. In contrast, firms in retail - with the exception of large retail store chains - and in particular professional services tend to be relatively small and labour-intensive, with professional services firms also being somewhat younger. Finally, firms in professional services are also less indebted, consistent with their lower capital intensity, whereas retail companies may need higher debt levels to purchase and maintain relatively high inventory levels.

25. The availability of leads or lags and external information on product market regulations further reduces the estimation sample. 
Table 2. Descriptive statistics on selected firm-level variables by industry

\begin{tabular}{|c|c|c|c|c|}
\hline & \multicolumn{2}{|c|}{ Network industries } & \multicolumn{2}{|c|}{ Retail } \\
\hline & Mean & St.Dev. & Mean & St.Dev \\
\hline Employment (log) & 2.3 & 1.0 & 1.9 & 0.8 \\
\hline Output (log) & 13.7 & 2.0 & 13.4 & 2.1 \\
\hline Value added (log) & 12.8 & 1.5 & 12.2 & 1.4 \\
\hline Capital intensity (K/L, log) & 10.0 & 1.9 & 9.0 & 2.0 \\
\hline $\begin{array}{l}\text { Indebtedness (total debt / } \\
\text { assets) }\end{array}$ & 0.24 & 2.2 & 0.26 & 24.88 \\
\hline \multirow[t]{3}{*}{ Age } & 18.9 & 14.4 & 19.7 & 17.4 \\
\hline & \multicolumn{2}{|c|}{ Professional services } & \multicolumn{2}{|c|}{ All other firms } \\
\hline & Mean & St.Dev. & Mean & St.Dev \\
\hline Employment (log) & 2.0 & 0.8 & 2.0 & 0.9 \\
\hline Output (log) & 13.0 & 1.7 & 13.4 & 2.0 \\
\hline Value added (log) & 12.8 & 1.5 & 12.2 & 1.4 \\
\hline Capital intensity $(\mathrm{K} / \mathrm{L}, \mathrm{log})$ & 8.7 & 1.9 & 9.2 & 2.0 \\
\hline $\begin{array}{l}\text { Indebtedness (total debt / } \\
\text { assets) }\end{array}$ & 0.15 & 1.28 & 0.24 & 19.63 \\
\hline Age & 15.8 & 9.5 & 18.8 & 15.7 \\
\hline
\end{tabular}

Note: Monetary variables are expressed in millions of 2005 PPP dollars.

\section{The short-term effects of product market reforms in network industries, retail and professional services}

\subsection{Baseline methodology}

The methodology for assessing the short to medium-term impact of product market reforms is based on the local projection estimator due to Jorda (2005) and Teulings and Zubanov (2014). ${ }^{26}$ This estimator allows for the robust estimation of impulse response functions by estimating its coefficients directly for each time horizon as opposed to deriving them indirectly from the estimates of a specific dynamic model, which are typically more sensitive to misspecification. Moreover, focusing directly on differences in the outcome variable of interest naturally allows controlling for country and industryspecific linear trends through the inclusion of country-industry dummies. This effectively relaxes the common trends assumption of the standard difference-in-difference estimator by transforming it into a triple-difference estimator. The main outcome variables considered are employment, capital stock, and gross output.

In the baseline regressions, the log difference in the outcome variable of interest $y$ between $t-1$ and $t+S$ in firm $i$ is modeled as follows:

(1) $y_{i t+s}-y_{i t-1}=\alpha+\sum_{s=-2}^{S} \beta_{s} R_{j c t+s}+\gamma X_{i t-1}+\eta_{c j}+\theta_{j t}+v_{c t}+\varepsilon_{i t} \forall s=0,1,2$

where $R_{j c t}$ refers to an indicator variable that equals one in the event of a major pro-competitive reform and minus one in the event of a major reform in the opposite direction in industry $j$, country $c$ and

26. This method has been applied to firm-level data by Stoyanov and Zubanov (2014). 
year $t$. In order to control for past reforms the first two lags of the reform indicator are also included. To control for reforms during the post-reform period the first lead is included when considering the impact of product market reforms at horizon $\mathrm{t}+1$ and the first two leads when considering its impact at horizon $\mathrm{t}+2$. The impulse response function is obtained by combining the coefficients $\beta_{0}$ for each time period $S$.

The empirical model further controls for wide variety of observable and unobservable factors. All observable factors are expressed in terms of categorical variables and lagged by one period. ${ }^{27}$ These include firm size measured in terms of the number of employees $(3-9 ; 10-19 ; 20+)$, age measured in years $(0-9 ; 10-24 ; 25+)$, debt leverage defined in terms of the debt to asset ratio (no debt; some debt, <0.25; high debt, $0.25+$ ), and labour productivity in terms of value added (bottom, middle, top tercile). It further includes industry*country fixed effects $\left(\eta_{c j}\right)$ to allow for differences in linear trends in the outcome variable of interest across country and industry pairs, country-time dummies $\left(v_{c t}\right)$ to control for differences in macro-economic developments across countries and industry-time dummies $\theta_{j t}$ to control for sectorspecific technological developments that are common across countries. ${ }^{28}$ Standard errors are robust and clustered by industry and country.

For the estimation, we impose the condition that our panel is "locally" balanced, such that over the four-year horizon, from $s=-1$ to $s=2$, there are no changes in the composition of the sample. This means that the results exclusively capture within-firm effects. From this perspective, it does not change the interpretation when firm fixed effects are included instead of country*industry fixed effects. However, since the panel is not fully or "globally" balanced the results are not identical. Firm-fixed effects will therefore be used in the sensitivity analysis.

\subsection{Baseline results}

The baseline results for employment, capital and output are reported in Table 3 and Figure 4. These focus on major reforms defined in terms of the absolute threshold (R1) with respect to either the overall restrictiveness of product market regulation (Table 3a and Panel A of Figure 4) or only that of barriers to entry (Table $3 \mathrm{~b}$ and Panel B of Figure 4).

The results indicate that the short-term effects of product market reforms on incumbent firms are positive and strengthen over time. The positive effects on output, and capital are immediate and increase to around 3\% for output and $4 \%$ for capital after two years. The impact on employment is smaller and only emerges after two years, reaching between 1.5 and $2 \%$. Given the relatively weak impact of product market reforms on employment compared with output, reforms also tend to increase labour productivity. The results are similar when focusing on the overall restrictiveness of product market regulation or entry barriers. This may indicate the results for reductions in the overall restrictiveness of product market regulations are to an important extent driven by reductions in entry barriers.

The firm-level controls suggest that larger and older firms tend to grow less fast than their smaller and younger counterparts who remain active. ${ }^{29}$ The impact of indebtedness on firm growth is $a$ priori ambiguous since it may reflect the importance of profitable investment opportunities or impede

27. Lagged categorical variables are used to alleviate any potential endogeneity concerns. Excluding these controls does not qualitatively change the results.

28. In order to control for country-time effects when considering individual industries, country-time averages are removed from all variables using the full set of PMR sectors before splitting the sample by sector.

29. Recent work by Decker et al. (2014) for the US suggests that the role of firm size may disappear when taking account of exit but that the positive effect of firm youth on growth remains. The more prominent role of firm age than size is also confirmed by Criscuolo et al. (2014) for 18 countries. 
investment by limiting further access to external finance. The results suggest that indebtedness is associated with less investment, but with more output growth. This could reflect the possibility that indebtedness captures the importance of past investment opportunities (increasing both indebtedness and output capacity), but may also become an obstacle to further investment in the future as access to credit is reduced. Excluding these firm-level controls does not have a significant impact on the results.

\section{Figure 4. The short-term effects of product market reforms on incumbent firms}

Percentage change in the outcome variable of interest in years after the reform

Panel A. Major reduction in the overall restrictiveness of product market regulation (R1)

Employment

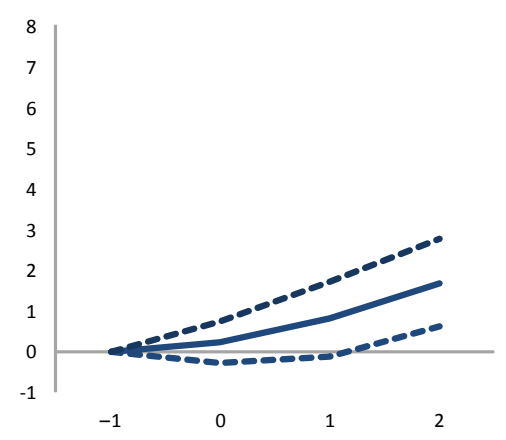

Capital

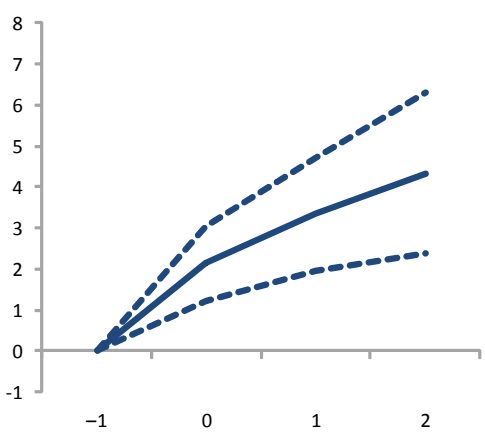

Output

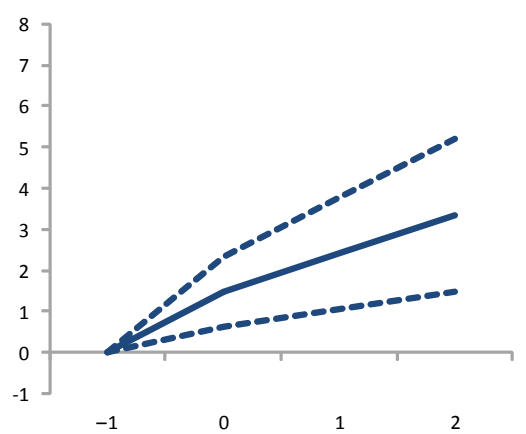

Panel B. Major reduction in entry barriers $(\mathrm{R} 1)$

Employment

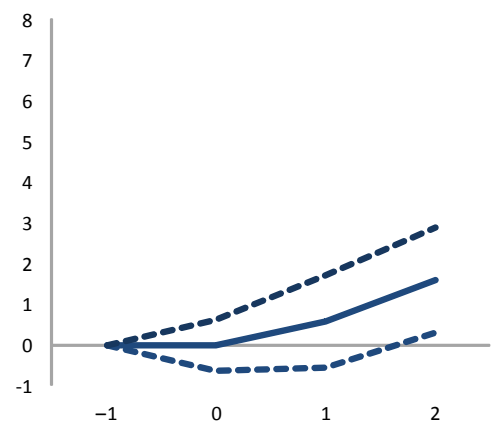

Capital

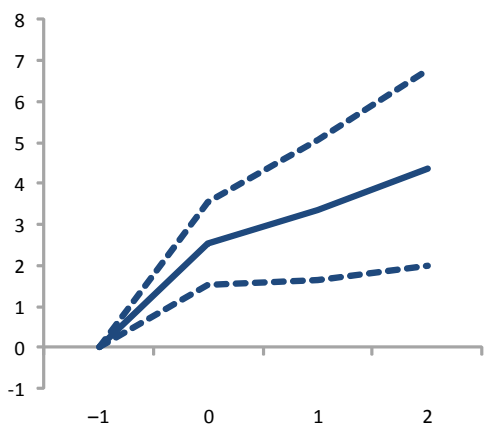

Output

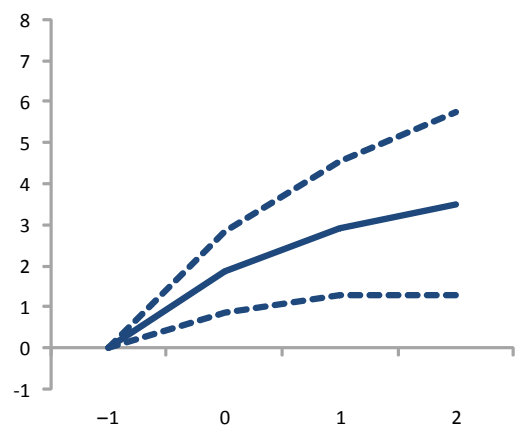

Note: Solid lines represent impulse response functions based on the estimated coefficients; dashed lines represent $90 \%$ confidence intervals. See Table 3a and Table3b for full details. 
Table 3a. The effects of a reduction in the overall restrictiveness of product market regulation

Percentage change in the outcome variable of interest in years after the reform

\begin{tabular}{|c|c|c|c|c|c|c|c|c|c|}
\hline & \multicolumn{3}{|c|}{ log employment (E) } & \multicolumn{3}{|c|}{ log capital (K) } & \multicolumn{3}{|c|}{ log output $(Y)$} \\
\hline & $t=0$ & $t=1$ & $t=2$ & $t=0$ & $t=1$ & $t=2$ & $\mathrm{t}=0$ & $t=1$ & $\mathrm{t}=2$ \\
\hline \multirow[t]{3}{*}{$R_{t}$} & 0.0022 & 0.0079 & 0.0168 & 0.0213 & 0.0334 & 0.0434 & 0.0150 & 0.0242 & 0.0334 \\
\hline & $(0.0032)$ & $(0.0057)$ & $(0.0065)$ & $(0.0056)$ & $(0.0084)$ & $(0.0120)$ & $(0.0052)$ & $(0.0082)$ & $(0.0114)$ \\
\hline & & & $* *$ & $* * *$ & $* * *$ & $* * *$ & $* * *$ & $* * *$ & $* * *$ \\
\hline \multirow[t]{3}{*}{ Medium sized firms $_{t-1}$} & -0.0470 & -0.0754 & -0.1025 & -0.0093 & -0.0126 & -0.0072 & -0.0064 & -0.0129 & -0.0144 \\
\hline & $(0.0052)$ & $(0.0074)$ & $(0.0092)$ & $(0.0026)$ & $(0.0043)$ & $(0.0064)$ & $(0.0015)$ & $(0.0023)$ & $(0.0032)$ \\
\hline & $* * *$ & $* * *$ & $* * *$ & $* * *$ & $* * *$ & & $* * *$ & $* * *$ & $* * *$ \\
\hline \multirow[t]{3}{*}{ Large firms $_{\mathrm{t}-1}$} & -0.0513 & -0.0809 & -0.1087 & -0.0085 & -0.0095 & 0.0036 & -0.0021 & -0.0031 & 0.0008 \\
\hline & $(0.0058)$ & $(0.0084)$ & $(0.0108)$ & $(0.0058)$ & $(0.0103)$ & $(0.0145)$ & $(0.0024)$ & $(0.0046)$ & $(0.0072)$ \\
\hline & $* * *$ & $* * *$ & $* * *$ & & & & & & \\
\hline \multirow[t]{3}{*}{ Mature firms $\mathrm{t}_{\mathrm{t}-1}$} & -0.0207 & -0.0353 & -0.0498 & -0.0514 & -0.0751 & -0.0907 & -0.0483 & -0.0712 & -0.0883 \\
\hline & $(0.0014)$ & $(0.0022)$ & $(0.0027)$ & $(0.0039)$ & $(0.0066)$ & $(0.0088)$ & $(0.0045)$ & $(0.0061)$ & $(0.0074)$ \\
\hline & $* * *$ & $* * *$ & $* * *$ & $* * *$ & $* * *$ & $* * *$ & $* * *$ & $* * *$ & $* * *$ \\
\hline \multirow[t]{3}{*}{ Old firms $t_{t-1}$} & -0.0265 & -0.0477 & -0.0689 & -0.0585 & -0.0916 & -0.1199 & -0.0540 & -0.0852 & -0.1112 \\
\hline & $(0.0012)$ & $(0.0019)$ & $(0.0027)$ & $(0.0048)$ & $(0.0074)$ & $(0.0093)$ & $(0.0051)$ & $(0.0068)$ & $(0.0083)$ \\
\hline & $* * *$ & $* * *$ & $* * *$ & $* * *$ & $* * *$ & $* * *$ & $* * *$ & $* * *$ & $* * *$ \\
\hline \multirow[t]{3}{*}{ Some debt $t_{t-1}$} & 0.0029 & 0.0040 & 0.0024 & -0.0441 & -0.0739 & -0.0902 & -0.0001 & -0.0026 & -0.0065 \\
\hline & $(0.0012)$ & $(0.0020)$ & $(0.0027)$ & $(0.0056)$ & $(0.0094)$ & $(0.0117)$ & $(0.0017)$ & $(0.0027)$ & $(0.0035)$ \\
\hline & $* *$ & $*$ & & $* * *$ & $* * *$ & $* * *$ & & & $*$ \\
\hline \multirow[t]{3}{*}{ High debt $t_{t-1}$} & 0.0010 & -0.0002 & -0.0037 & -0.0773 & -0.1331 & -0.1694 & 0.0107 & 0.0118 & 0.0059 \\
\hline & $(0.0015)$ & $(0.0024)$ & $(0.0028)$ & $(0.0078)$ & $(0.0137)$ & $(0.0183)$ & $(0.0020)$ & $(0.0033)$ & $(0.0044)$ \\
\hline & & & & $* * *$ & $* * *$ & $* * *$ & $* * *$ & $* * *$ & \\
\hline \multirow[t]{3}{*}{ Medium productivity $\mathrm{t}_{\mathrm{-}-1}$} & 0.0402 & 0.0587 & 0.0696 & -0.0055 & -0.0073 & -0.0046 & -0.0302 & -0.0305 & -0.0255 \\
\hline & $(0.0036)$ & $(0.0042)$ & $(0.0043)$ & $(0.0031)$ & $(0.0063)$ & $(0.0104)$ & $(0.0023)$ & $(0.0029)$ & $(0.0039)$ \\
\hline & $* * *$ & $* * *$ & $* * *$ & $*$ & & & $* * *$ & $* * *$ & $* * *$ \\
\hline \multirow[t]{3}{*}{ High productivity $\mathrm{t}_{\mathrm{t}-1}$} & 0.0833 & 0.1228 & 0.1506 & 0.0008 & 0.0029 & 0.0139 & -0.0423 & -0.0423 & -0.0317 \\
\hline & $(0.0072)$ & $(0.0092)$ & $(0.0106)$ & $(0.0053)$ & $(0.0101)$ & $(0.0164)$ & $(0.0049)$ & $(0.0063)$ & $(0.0078)$ \\
\hline & $* * *$ & $* * *$ & $* * *$ & & & & $* * *$ & $* * *$ & $* * *$ \\
\hline \multirow[t]{3}{*}{ Constant } & 0.6179 & 0.4188 & 0.3410 & -0.0425 & -0.3542 & -0.7010 & 0.2163 & 0.2242 & -0.2036 \\
\hline & $(0.0522)$ & $(0.0749)$ & $(0.0769)$ & $(0.0144)$ & $(0.0241)$ & $(0.0334)$ & $(0.0738)$ & $(0.0893)$ & $(0.1044)$ \\
\hline & $* * *$ & $* * *$ & $* * *$ & $* * *$ & $* * *$ & $* * *$ & $* * *$ & $* *$ & $*$ \\
\hline Past and future reforms & YES & YES & YES & YES & YES & YES & YES & YES & YES \\
\hline Country*industry dummies & YES & YES & YES & YES & YES & YES & YES & YES & YES \\
\hline Country*year dummies & YES & YES & YES & YES & YES & YES & YES & YES & YES \\
\hline Industry*year dummies & YES & YES & YES & YES & YES & YES & YES & YES & YES \\
\hline Observations & 776,900 & 776,900 & 776,900 & 611,201 & 611,201 & 611,201 & 776,900 & 776,900 & 776,900 \\
\hline R-squared & 0.0299 & 0.0431 & 0.0519 & 0.0083 & 0.0116 & 0.0133 & 0.0169 & 0.0225 & 0.0249 \\
\hline
\end{tabular}

Note: Standard errors are robust and clustered by country and industry. ${ }^{*},{ }^{* *},{ }^{* * *}$ refer to statistical significance levels of $10 \%, 5 \%$ and $1 \%$ respectively. 
ECO/WKP(2016)35

Table $3 b$. The effects of a reduction in entry barriers

Percentage change in the outcome variable of interest in years after the reform

\begin{tabular}{|c|c|c|c|c|c|c|c|c|c|}
\hline & \multicolumn{3}{|c|}{ log employment (E) } & \multicolumn{3}{|c|}{ log capital (K) } & \multicolumn{3}{|c|}{ log output $(Y)$} \\
\hline & $t=0$ & $t=1$ & $t=2$ & $t=0$ & $t=1$ & $t=2$ & $\mathrm{t}=0$ & $t=1$ & $\mathrm{t}=2$ \\
\hline \multirow[t]{3}{*}{$R_{t}$} & -0.0002 & 0.0057 & 0.0159 & 0.0254 & 0.0336 & 0.0438 & 0.0186 & 0.0291 & 0.0351 \\
\hline & $(0.0038)$ & $(0.0070)$ & $(0.0079)$ & $(0.0061)$ & $(0.0104)$ & $(0.0145)$ & $(0.0060)$ & $(0.0100)$ & $(0.0136)$ \\
\hline & & & $* *$ & $* * *$ & $* * *$ & $* * *$ & $* * *$ & $* * *$ & $* *$ \\
\hline \multirow[t]{3}{*}{ Medium sized firms ${ }_{t-1}$} & -0.0472 & -0.0757 & -0.1029 & -0.0097 & -0.0133 & -0.0079 & -0.0066 & -0.0132 & -0.0147 \\
\hline & $(0.0052)$ & $(0.0074)$ & $(0.0092)$ & $(0.0026)$ & $(0.0044)$ & $(0.0065)$ & $(0.0015)$ & $(0.0023)$ & $(0.0031)$ \\
\hline & $* * *$ & $* * *$ & $* * *$ & $* * *$ & $* * *$ & & $* * *$ & $* * *$ & $* * *$ \\
\hline \multirow[t]{3}{*}{ Large firms $\mathrm{t}_{-1}$} & -0.0517 & -0.0814 & -0.1091 & -0.0089 & -0.0099 & 0.0029 & -0.0023 & -0.0034 & 0.0005 \\
\hline & $(0.0058)$ & $(0.0085)$ & $(0.0108)$ & $(0.0058)$ & $(0.0104)$ & $(0.0145)$ & $(0.0023)$ & $(0.0046)$ & $(0.0071)$ \\
\hline & $* * *$ & $* * *$ & $* * *$ & & & & & & \\
\hline \multirow[t]{3}{*}{ Mature firms $\mathrm{t}_{\mathrm{t}-1}$} & -0.0207 & -0.0352 & -0.0498 & -0.0519 & -0.0758 & -0.0917 & -0.0482 & -0.0712 & -0.0882 \\
\hline & $(0.0014)$ & $(0.0022)$ & $(0.0027)$ & $(0.0040)$ & $(0.0068)$ & $(0.0090)$ & $(0.0044)$ & $(0.0060)$ & $(0.0074)$ \\
\hline & $* * *$ & $* * *$ & $* * *$ & $* * *$ & $* * *$ & $* * *$ & $* * *$ & $* * *$ & $* * *$ \\
\hline \multirow[t]{3}{*}{ Old firms $\mathrm{t}_{-1}$} & -0.0264 & -0.0475 & -0.0686 & -0.0588 & -0.0919 & -0.1202 & -0.0538 & -0.0848 & -0.1106 \\
\hline & $(0.0012)$ & $(0.0019)$ & $(0.0027)$ & $(0.0049)$ & $(0.0075)$ & $(0.0093)$ & $(0.0050)$ & $(0.0068)$ & $(0.0083)$ \\
\hline & $* * *$ & $* * *$ & $* * *$ & $* * *$ & $* * *$ & $* * *$ & $* * *$ & $* * *$ & $* * *$ \\
\hline \multirow[t]{3}{*}{ Some debt $t_{t-1}$} & 0.0029 & 0.0040 & 0.0022 & -0.0444 & -0.0745 & -0.0911 & -0.0002 & -0.0029 & -0.0070 \\
\hline & $(0.0012)$ & $(0.0020)$ & $(0.0026)$ & $(0.0055)$ & $(0.0093)$ & $(0.0115)$ & $(0.0017)$ & $(0.0026)$ & $(0.0035)$ \\
\hline & $* *$ & $*$ & & $* * *$ & $* * *$ & $* * *$ & & & $* *$ \\
\hline \multirow[t]{3}{*}{ High debt $t_{t-1}$} & 0.0011 & -0.0002 & -0.0038 & -0.0778 & -0.1338 & -0.1705 & 0.0106 & 0.0116 & 0.0056 \\
\hline & $(0.0015)$ & $(0.0024)$ & $(0.0028)$ & $(0.0077)$ & $(0.0136)$ & $(0.0181)$ & $(0.0019)$ & $(0.0032)$ & $(0.0042)$ \\
\hline & & & & $* * *$ & $* * *$ & $* * *$ & $* * *$ & $* * *$ & \\
\hline \multirow[t]{3}{*}{ Medium productivity $\mathrm{t}_{\mathrm{t}-1}$} & 0.0404 & 0.0590 & 0.0701 & -0.0058 & -0.0079 & -0.0054 & -0.0308 & -0.0312 & -0.0262 \\
\hline & $(0.0036)$ & $(0.0042)$ & $(0.0043)$ & $(0.0030)$ & $(0.0063)$ & $(0.0103)$ & $(0.0025)$ & $(0.0031)$ & $(0.0041)$ \\
\hline & $* * *$ & $* * *$ & $* * *$ & $*$ & & & $* * *$ & $* * *$ & $* * *$ \\
\hline \multirow[t]{3}{*}{ High productivity $\mathrm{t}-1_{1}$} & 0.0835 & 0.1231 & 0.1509 & 0.0007 & 0.0025 & 0.0132 & -0.0432 & -0.0437 & -0.0333 \\
\hline & $(0.0072)$ & $(0.0092)$ & $(0.0106)$ & $(0.0053)$ & $(0.0101)$ & $(0.0163)$ & $(0.0053)$ & $(0.0069)$ & $(0.0085)$ \\
\hline & $* * *$ & $* * *$ & $* * *$ & & & & $* * *$ & $* * *$ & $* * *$ \\
\hline \multirow[t]{3}{*}{ Constant } & 0.6118 & 0.4076 & 0.3191 & -0.0474 & -0.3616 & -0.7080 & 0.2182 & 0.2203 & -0.1921 \\
\hline & $(0.0528)$ & $(0.0767)$ & $(0.0781)$ & $(0.0142)$ & $(0.0231)$ & $(0.0326)$ & $(0.0750)$ & $(0.0921)$ & (0.1089) \\
\hline & $* * *$ & $* * *$ & $* * *$ & $* * *$ & $* * *$ & $* * *$ & $* * *$ & $* *$ & $*$ \\
\hline Past and future reforms & YES & YES & YES & YES & YES & YES & YES & YES & YES \\
\hline Country*industry dummies & YES & YES & YES & YES & YES & YES & YES & YES & YES \\
\hline Country*year dummies & YES & YES & YES & YES & YES & YES & YES & YES & YES \\
\hline Industry*year dummies & YES & YES & YES & YES & YES & YES & YES & YES & YES \\
\hline Observations & 779,737 & 779,737 & 779,737 & 614,050 & 614,050 & 614,050 & 779,737 & 779,737 & 779,737 \\
\hline R-squared & 0.0301 & 0.0433 & 0.0520 & 0.0084 & 0.0119 & 0.0136 & 0.0169 & 0.0223 & 0.0242 \\
\hline
\end{tabular}

Note: Standard errors are robust and clustered by country and industry. ${ }^{*},{ }^{* *},{ }^{* * *}$ refer to statistical significance levels of $10 \%, 5 \%$ and $1 \%$ respectively.

Table 4 summarises the results using different reforms measures by focusing on the coefficients that define the impulse response function only. It reports results for the three measures of major reforms as well as the change in the extended OECD indicator. Panel A focuses on the overall restrictiveness of product market regulation, whereas Panel B focuses on barriers to entry. The results are qualitatively similar across each of the four measures of product market reforms in terms of the relative size of the 
effects across outcomes variables as well as the shape of the impulse response function. ${ }^{30}$ This is reassuring since this suggests that the results are not driven by the specific way reforms are defined. Moreover, the results are rather similar when focusing on the overall restrictiveness of product market regulations and when focusing on barriers to entry. As mentioned above, this may reflect the possibility that much of the reform activity with respect to product market regulations relates to the barriers to entry. ${ }^{31}$

Table 4. Results by reform measure

Percentage change in the outcome variable of interest in years after the reform, selected coefficients

\begin{tabular}{|c|c|c|c|c|c|c|c|c|c|c|}
\hline & & \multicolumn{3}{|c|}{ log employment (L) } & \multicolumn{3}{|c|}{ log capital (K) } & \multicolumn{3}{|c|}{ log output $(Y)$} \\
\hline & & $t=0$ & $t=1$ & $t=2$ & $t=0$ & $t=1$ & $t=2$ & $t=0$ & $t=1$ & $t=2$ \\
\hline \multicolumn{11}{|c|}{ Panel A. Overall indicator } \\
\hline (1a) & Absolute threshold (R1) & $\begin{array}{c}0.0022 \\
(0.0032)\end{array}$ & $\begin{array}{c}0.0079 \\
(0.0057)\end{array}$ & $\begin{array}{c}0.0168 \\
(0.0065) \\
\star \star\end{array}$ & $\begin{array}{c}0.0213 \\
(0.0056) \\
\star \star \star\end{array}$ & $\begin{array}{c}0.0334 \\
(0.0084) \\
\star \star \star\end{array}$ & $\begin{array}{c}0.0434 \\
(0.0120) \\
\star \star *\end{array}$ & $\begin{array}{c}0.0150 \\
(0.0052) \\
\star \star \star\end{array}$ & $\begin{array}{c}0.0242 \\
(0.0082) \\
\star \star \star\end{array}$ & $\begin{array}{c}0.0334 \\
(0.0114) \\
* \star \star\end{array}$ \\
\hline (2a) & Mixed threshold (R2) & $\begin{array}{c}0.0027 \\
(0.0033)\end{array}$ & $\begin{array}{c}0.0085 \\
(0.0058)\end{array}$ & $\begin{array}{c}0.0172 \\
(0.0066) \\
\star \star\end{array}$ & $\begin{array}{c}0.0210 \\
(0.0057) \\
\star \star \star\end{array}$ & $\begin{array}{c}0.0318 \\
(0.0085) \\
\star \star \star\end{array}$ & $\begin{array}{c}0.0419 \\
(0.0124) \\
\star \star *\end{array}$ & $\begin{array}{c}0.0149 \\
(0.0054) \\
\star \star *\end{array}$ & $\begin{array}{c}0.0245 \\
(0.0083) \\
\star \star \star\end{array}$ & $\begin{array}{c}0.0346 \\
(0.0116) \\
\star \star \star\end{array}$ \\
\hline (3a) & Narrative approach (R3) & $\begin{array}{c}0.0024 \\
(0.0040)\end{array}$ & $\begin{array}{c}0.0090 \\
(0.0072)\end{array}$ & $\begin{array}{c}0.0144 \\
(0.0088)\end{array}$ & $\begin{array}{c}0.0210 \\
(0.0075) \\
\star \star *\end{array}$ & $\begin{array}{c}0.0234 \\
(0.0120) \\
*\end{array}$ & $\begin{array}{c}0.0258 \\
(0.0164)\end{array}$ & $\begin{array}{c}0.0189 \\
(0.0061) \\
\star \star \star\end{array}$ & $\begin{array}{c}0.0316 \\
(0.0098) \\
\star \star \star\end{array}$ & $\begin{array}{c}0.0459 \\
(0.0139) \\
\star \star \star\end{array}$ \\
\hline$(4 a)$ & OECD indicator & $\begin{array}{c}0.0001 \\
(0.0017)\end{array}$ & $\begin{array}{c}0.003 \\
(0.0027)\end{array}$ & $\begin{array}{c}0.0083 \\
(0.0032) \\
\star \star\end{array}$ & $\begin{array}{c}0.0193 \\
(0.0044) \\
\star \star \star\end{array}$ & $\begin{array}{c}0.0343 \\
(0.0052) \\
\star \star \star\end{array}$ & $\begin{array}{c}0.0406 \\
(0.0059) \\
\star \star *\end{array}$ & $\begin{array}{c}0.0092 \\
(0.0037) \\
* \star\end{array}$ & $\begin{array}{c}0.0123 \\
(0.0059) \\
* \star\end{array}$ & $\begin{array}{c}0.0128 \\
(0.0068) \\
*\end{array}$ \\
\hline \multicolumn{11}{|c|}{ Panel A. Entry indicator } \\
\hline (1b) & Absolute threshold (R1) & $\begin{array}{l}-0.0002 \\
(0.0038)\end{array}$ & $\begin{array}{c}0.0057 \\
(0.0070)\end{array}$ & $\begin{array}{c}0.0159 \\
(0.0079) \\
\star \star\end{array}$ & $\begin{array}{c}0.0254 \\
(0.0061) \\
\star \star \star\end{array}$ & $\begin{array}{c}0.0336 \\
(0.0104) \\
\star \star \star\end{array}$ & $\begin{array}{c}0.0438 \\
(0.0145) \\
\star \star *\end{array}$ & $\begin{array}{c}0.0186 \\
(0.0060) \\
\star \star *\end{array}$ & $\begin{array}{c}0.0291 \\
(0.0100) \\
\star \star \star\end{array}$ & $\begin{array}{c}0.0351 \\
(0.0136) \\
\star \star\end{array}$ \\
\hline (2b) & Mixed threshold (R2) & $\begin{array}{l}-0.0010 \\
(0.0023)\end{array}$ & $\begin{array}{c}0.0023 \\
(0.0038)\end{array}$ & $\begin{array}{c}0.0089 \\
(0.0047) \\
*\end{array}$ & $\begin{array}{c}0.0261 \\
(0.0054) \\
* \star \star\end{array}$ & $\begin{array}{c}0.0333 \\
(0.0093) \\
\star \star \star\end{array}$ & $\begin{array}{c}0.0427 \\
(0.0124) \\
* * *\end{array}$ & $\begin{array}{c}0.0121 \\
(0.0054) \\
* *\end{array}$ & $\begin{array}{c}0.0153 \\
(0.0085) \\
*\end{array}$ & $\begin{array}{c}0.0136 \\
(0.0112)\end{array}$ \\
\hline (3b) & Narrative approach (R3) & $\begin{array}{l}-0.0000 \\
(0.0042)\end{array}$ & $\begin{array}{c}0.0082 \\
(0.0074)\end{array}$ & $\begin{array}{c}0.0170 \\
(0.0086) \\
*\end{array}$ & $\begin{array}{c}0.0200 \\
(0.0075) \\
\star \star \star\end{array}$ & $\begin{array}{c}0.0227 \\
(0.0121) \\
*\end{array}$ & $\begin{array}{c}0.0262 \\
(0.0169)\end{array}$ & $\begin{array}{c}0.0206 \\
(0.0063) \\
\star \star \star\end{array}$ & $\begin{array}{c}0.0344 \\
(0.0106) \\
\star \star \star\end{array}$ & $\begin{array}{c}0.0448 \\
(0.0143) \\
\star \star \star\end{array}$ \\
\hline$(4 b)$ & OECD indicator & $\begin{array}{c}0.0003 \\
(0.0027)\end{array}$ & $\begin{array}{c}0.0044 \\
(0.0050)\end{array}$ & $\begin{array}{c}0.0098 \\
(0.0055) \\
*\end{array}$ & $\begin{array}{c}0.0193 \\
(0.0040) \\
\star \star \star\end{array}$ & $\begin{array}{c}0.0261 \\
(0.0061) \\
\star \star \star\end{array}$ & $\begin{array}{c}0.0312 \\
(0.0093) \\
\star \star \star\end{array}$ & $\begin{array}{c}0.0131 \\
(0.0039) \\
\star \star \star\end{array}$ & $\begin{array}{c}0.0195 \\
(0.0064) \\
\star \star \star\end{array}$ & $\begin{array}{c}0.0181 \\
(0.0082) \\
\star \star\end{array}$ \\
\hline & Observations & 776,900 & 776,900 & 776,900 & 611,201 & 611,201 & 611,201 & 776,900 & 776,900 & 776,900 \\
\hline
\end{tabular}

Note: Regressions control for reforms in the previous and subsequent two years, include firm-level controls, as well as countryindustry dummies, country-year dummies and industry-year dummies. Standard errors are robust and clustered by country and industry. ${ }^{*},{ }^{* \star},{ }^{* \star *}$ refer to statistical significance levels of $10 \%, 5 \%$ and $1 \%$ respectively.

30. Strictly speaking, one should be careful comparing the size of the coefficients that are obtained using the major reform indicators from those obtained using the extended OECD indicators as these are not measured in the same metric. Nevertheless, the results are very similar which suggests that the typical major reform corresponds to about a one point change in the extended OECD indicator. This is indeed reasonable.

31. Note that when using the relative threshold of major reforms the threshold based on the overall restrictiveness of product market regulations was used rather than that specifically relating to barriers to entry. Since this may not be ideal this may explain the weak results using the relative threshold in the context of entry barriers. It also explains the large number of major reforms as documented in Table A3. 
The results based on the measure of major reforms that uses the narrative approach are most closely comparable to results by Bouis et al (2016) at the sector and country-level since they use the same measure of major reforms. ${ }^{32}$ The medium term results for employment and output at $t=2$ are qualitatively and quantitatively similar. This may either suggest that the effects of product market reforms on the entry and exit of firms are not that important or that the effects on entry and exit approximately cancel each other out. However, the positive effects appear to materialise somewhat more quickly in the present paper. This may reflect our emphasis on the typical firm, which is relatively small and affected more positively by product market reforms, at least in network industries. It may also be that sector-level studies capture the fact that the effect on entry takes some time to materialise whereas the impact on exit is more immediate.

Both the size of the reform and the initial restrictiveness of product market regulations appear to matters. Panel A of Table 5 documents the effects of respectively small reforms defined in terms of reductions (increases) in the overall restrictive of product market regulation of between 0 and 0.25 , modest reforms defined in terms of reductions (increases) between 0.25 and 0.5 and major reforms defined as reductions (increases) of one half or more. The results indicate that the minor or modest reforms have effectively no effects, with the possible exception with modest reforms in the case of investment. This suggests that concentrating on major reforms does not substantially reduce the policy variation in the data. Panel B of Table 5 documents how the results differ depending on the initial restrictiveness of product market regulations. For the present purposes, initial restrictiveness is defined in terms of the terciles of the distribution of the extended PMR indicator across countries and years within each industry. The results indicate that the short-term effects of pro-competitive reforms are more positive the lower the initial restrictiveness of product market regulations. One possible explanation for this is that major reforms in the context of strict initial regulations have both larger short-term costs (smaller short-term benefits) but also longer short-term benefits.

Table 5. Results by absolute reform size and initial regulatory stance

Percentage change in the outcome variable of interest in years after a reduction in the overall restrictiveness of product market regulation, selected coefficients

Panel A. Results by the absolute reform size

\begin{tabular}{|c|c|c|c|c|c|c|c|c|c|}
\hline & \multicolumn{3}{|c|}{ log employment (L) } & \multicolumn{3}{|c|}{ log capital (K) } & \multicolumn{3}{|c|}{$\log$ output $(Y)$} \\
\hline & $t=0$ & $t=1$ & $t=2$ & $t=0$ & $t=1$ & $t=2$ & $t=0$ & $t=1$ & $t=2$ \\
\hline $\begin{array}{l}\text { Major reform } \\
\text { - larger than } 0.5\end{array}$ & $\begin{array}{c}0.0012 \\
(0.0034)\end{array}$ & $\begin{array}{c}0.0034 \\
(0.0060)\end{array}$ & $\begin{array}{c}0.0132 \\
(0.0070) \\
\star\end{array}$ & $\begin{array}{c}0.0206 \\
(0.0052) \\
* \star \star\end{array}$ & $\begin{array}{c}0.0322 \\
(0.0099) \\
* * \star\end{array}$ & $\begin{array}{c}0.0462 \\
(0.0160) \\
\star \star \star \star\end{array}$ & $\begin{array}{c}0.0130 \\
(0.0056) \\
\star \star\end{array}$ & $\begin{array}{c}0.0176 \\
\underset{* \star}{0.0086)}\end{array}$ & $\begin{array}{c}0.0256 \\
(0.0121) \\
* *\end{array}$ \\
\hline $\begin{array}{l}\text { Modest reform } \\
\text { - between } 0.25 \text { and } 0.5\end{array}$ & $\begin{array}{c}0.0018 \\
(0.0023)\end{array}$ & $\begin{array}{c}0.0030 \\
(0.0035)\end{array}$ & $\begin{array}{c}0.0008 \\
(0.0052)\end{array}$ & $\begin{array}{c}0.0169 \\
(0.0055) \\
* \star \star\end{array}$ & $\begin{array}{c}0.0260 \\
(0.0101) \\
* *\end{array}$ & $\begin{array}{c}0.0342 \\
\underset{* \star}{0.0136)}\end{array}$ & $\begin{array}{l}0.0058 \\
(0.0045)\end{array}$ & $\begin{array}{l}0.0136 \\
(0.0084)\end{array}$ & $\begin{array}{l}0.0096 \\
(0.0111)\end{array}$ \\
\hline $\begin{array}{l}\text { Minor reform } \\
\text { - between } 0 \text { and } 0.25\end{array}$ & $\begin{array}{l}-0.0006 \\
(0.0009)\end{array}$ & $\begin{array}{l}-0.0017 \\
(0.0018)\end{array}$ & $\begin{array}{l}-0.0006 \\
(0.0025)\end{array}$ & $\begin{array}{l}-0.0050 \\
(0.0031)\end{array}$ & $\begin{array}{c}0.0002 \\
(0.0046)\end{array}$ & $\begin{array}{c}0.0031 \\
(0.0059)\end{array}$ & $\begin{array}{l}-0.0008 \\
(0.0028)\end{array}$ & $\begin{array}{l}-0.0005 \\
(0.0045)\end{array}$ & $\begin{array}{l}-0.0038 \\
(0.0059)\end{array}$ \\
\hline $\mathrm{N}$ & 776,900 & 776,900 & 776,900 & 611,201 & 611,201 & 611,201 & 776,900 & 776,900 & 776,900 \\
\hline
\end{tabular}

32. However, in contrast to the present analysis these studies do not take account of retail and professional services. Since the indicators based on the narrative approach are not available for those sectors, the absolute threshold definition is used for these sectors. 
Panel B. Results by initial level of restrictiveness

by tercile within industries

\begin{tabular}{|c|c|c|c|c|c|c|c|c|c|}
\hline & \multicolumn{3}{|c|}{ log employment (L) } & \multicolumn{3}{|c|}{ log capital (K) } & \multicolumn{3}{|c|}{ log output $(Y)$} \\
\hline & $t=0$ & $t=1$ & $t=2$ & $t=0$ & $t=1$ & $t=2$ & $t=0$ & $t=1$ & $t=2$ \\
\hline $\begin{array}{l}\text { Base effect } \\
\text { - bottom tercile }\end{array}$ & $\begin{array}{c}0.0138 \\
(0.0048) \\
\star \star \star\end{array}$ & $\begin{array}{c}0.0215 \\
(0.0068) \\
* * \star\end{array}$ & $\begin{array}{c}0.0365 \\
(0.0087) \\
* \star \star\end{array}$ & $\begin{array}{l}-0.0003 \\
(0.0055)\end{array}$ & $\begin{array}{c}0.0044 \\
(0.0204)\end{array}$ & $\begin{array}{c}0.0295 \\
(0.0215)\end{array}$ & $\begin{array}{c}0.0102 \\
(0.0078)\end{array}$ & $\begin{array}{c}0.0299 \\
(0.0093) \\
* * *\end{array}$ & $\begin{array}{c}0.0561 \\
(0.0109) \\
\star \star \star\end{array}$ \\
\hline $\begin{array}{l}\text { Differential effect } \\
\text { - middle tercile }\end{array}$ & $\begin{array}{c}0.0010 \\
(0.0095)\end{array}$ & $\begin{array}{c}0.0001 \\
(0.0128)\end{array}$ & $\begin{array}{l}-0.0183 \\
(0.0134)\end{array}$ & $\begin{array}{c}0.0040 \\
(0.0240)\end{array}$ & $\begin{array}{l}-0.0015 \\
(0.0448)\end{array}$ & $\begin{array}{l}-0.0540 \\
(0.0618)\end{array}$ & $\begin{array}{l}-0.0153 \\
(0.0142)\end{array}$ & $\begin{array}{l}-0.0133 \\
(0.0159)\end{array}$ & $\begin{array}{c}0.0106 \\
(0.0288)\end{array}$ \\
\hline $\begin{array}{l}\text { Differential effect } \\
\text { - top tercile }\end{array}$ & $\begin{array}{c}-0.0180 \\
\underset{* \star *}{(0.0055)}\end{array}$ & $\begin{array}{c}-0.0236 \\
\underset{* \star}{(0.0093)}\end{array}$ & $\begin{array}{c}-0.0325 \\
\underset{* * \star}{(0.0114)}\end{array}$ & $\begin{array}{c}0.0251 \\
\underset{* \star}{(0.0108)}\end{array}$ & $\begin{array}{c}0.0312 \\
(0.0234)\end{array}$ & $\begin{array}{c}0.0042 \\
(0.0262)\end{array}$ & $\begin{array}{c}0.0055 \\
(0.0103)\end{array}$ & $\begin{array}{l}-0.0102 \\
(0.0132)\end{array}$ & $\begin{array}{c}-0.0362 \\
(0.0146) \\
\star \star\end{array}$ \\
\hline $\mathrm{N}$ & 742,537 & 742,537 & 742,537 & 590,766 & 590,766 & 590,766 & 742,537 & 742,537 & 742,537 \\
\hline
\end{tabular}

Note: Regressions control for reforms in the previous and subsequent two years, include firm-level controls, as well as countryindustry dummies, country-year dummies and industry-year dummies. Standard errors are robust and clustered by country and industry. ${ }^{*},{ }^{* *},{ }^{* *}$ refer to statistical significance levels of $10 \%, 5 \%$ and $1 \%$ respectively.

\subsection{Sensitivity analysis}

Product market reforms tend to be conducted when economic conditions are weak (Duval et al., 2016b; IMF, 2016). This creates a potential endogeneity problem which is likely to downward bias the estimates. The rich dummy structure, and particularly the country-time dummies, already controls for the role of economy-wide business conditions. Nevertheless, it cannot be excluded that product market reforms respond to sector-specific business conditions as well. ${ }^{33}$

In order to address the possibility that product market reforms respond to sector-specific business conditions, we pursue an instrumental variable strategy that attempts to purge the variation in reforms driven by sector-specific business conditions from our reform indicator. We use two alternative instruments (Table 6, rows 1 to 2): i) the overall restrictiveness of product market regulation in the previous year, as measured by the lagged level of the extended OECD indicator, which represents an absolute measure of reform pressure; ii) the relative restrictiveness of product market regulation, measured by the difference between the OECD indicator and its average level in other industries in the same country compared that in other countries. ${ }^{34}$ Each of these measures has a positive and statistically significant impact on the probability of observing a pro-competitive reform (see Table A8 in the Annex A4). These instruments can be considered exogenous as long as they are uncorrelated with future changes in the growth rate in the outcome variable of interest. While reforms are likely to be correlated to the growth rate in levels they are less likely to be correlated to changes relative to the country*industry trend. There is some indication that the instrumental variable estimates strengthen the estimated impact of product market reforms, at least in the case of capital and employment. This is consistent with the idea that reforms are taken in response to weak sectoral performance.

33. Another concern may that product market reforms may be implemented in conjunction with structural reforms in other policy domains. However, such reforms are likely to be country-wide and hence tend to be controlled for through the inclusion of country-year dummies.

34. The comparison across countries addresses the concern that the OECD indicators are mainly designed to make comparisons across countries but not within countries. 
As an alternative approach, we also attempt to control for sector-specific conditions directly through the inclusion of an indicator that captures the demand for an industry's output by downstream industries in the spirit of Baily et al. (2001), Bems et al. (2011) and Eaton et al. (2011) (Table 6, row 3). This allows focusing on the impact of product market reforms conditional on sector-level business conditions. We measure such linkages at the sector level by output growth in downstream industries weighted by their intermediate input use from upstream producers using the World Input-Output Database (WIOD). The results are qualitatively very similar to those reported for the baseline specification. This suggests that the correlation between product market reforms and output demand from firms in downstream industries is weak.

The baseline results control for country*industry fixed effects because this corresponds to the variation in our reform indicators. An alternative possibility is to include of firm-fixed effects instead (Table 6, row 4). This does not change the interpretation of the results since the data are locally balanced over each four-year horizon from $t-1$ to $t+2$, there are no changes in the composition of the sample - and hence the results already reflect within-firm effects. However, controlling for firm-fixed effects could affect the efficiency of the estimates by controlling more effectively for any unobserved time-invariant factors. The results are similar to those in our baseline specification.

The baseline results focus on the typical response of firms in the dataset to competitionenhancing product market reforms. In order to get an indication of the aggregate effects of product market reforms, we also present results based on weighted least squares that use the average level of employment as weights (Table 6, row 5). This yields an estimate for the aggregate effect of product market reforms which reflects the importance of firms in terms of employment. To the extent that the data cover the large majority of large firms in all countries and industries and the weight of small firms is relatively small in aggregate employment, this is similar to the aggregate effect of product market reforms in the population of firms. ${ }^{35}$ The results suggest that the effects of competition-enhancing product market reforms are also likely to be statistically significant and positive in the aggregate, but may be significantly larger than the effect for the typical firm. Firm size differences in the impacts are explored in more depth in Section 5.

Finally, we conducted a falsification test by assessing how the results change when we focus on a reform that takes place after our observation window at $s=3$ and hence should not affect the results in the absence of anticipation effects. The results indicate that this is the case, except when considering major reductions in the overall restrictiveness of product market regulation for output (Table 6, row 6). The role of anticipation effects in the case of output may explain why the results for output are not statistically significant in all specifications, despite there being significant effects for employment and capital.

35. The role of small firms remains understated in these weighted regressions given their relatively low coverage in the sample compared to large firms. However, their combined employment weight in the population aggregate is lower than that of large firms for the most advanced economies (see for instance Figure 3 in Criscuolo et al, 2014), implying that using employment weights indeed yields results closer to the aggregate effects. However, this still differs importantly from industry-level estimates as the present results effectively weigh each country*industry cell by their importance in terms of employment, whereas country- or industry-level studies typically assume that all country-industry cells or all countries have equal weight. 
Table 6. Sensitivity analysis

$\%$ change in the outcome variable of interest in years after major reform, selected coefficients

\begin{tabular}{|c|c|c|c|c|c|c|c|c|c|c|}
\hline & & \multicolumn{3}{|c|}{ log employment (L) } & \multicolumn{3}{|c|}{ log capital (K) } & \multicolumn{3}{|c|}{ log output $(Y)$} \\
\hline & & $t=0$ & $t=1$ & $t=2$ & $t=0$ & $t=1$ & $t=2$ & $t=0$ & $t=1$ & $t=2$ \\
\hline \multicolumn{11}{|c|}{ Overall restrictiveness } \\
\hline (1a) & IV - absolute reform pressure & $\begin{array}{c}0.0022 \\
(0.0084)\end{array}$ & $\begin{array}{c}0.0106 \\
(0.0109)\end{array}$ & $\begin{array}{c}0.0229 \\
(0.0142)\end{array}$ & $\begin{array}{c}0.0386 \\
\underset{* \star \star}{(0.0130)}\end{array}$ & $\begin{array}{c}0.0855 \\
\underset{* \star \star}{(0.0201)}\end{array}$ & $\begin{array}{c}0.1307 \\
\underset{* \star \star}{(0.0269)}\end{array}$ & $\begin{array}{c}0.0194 \\
(0.0155)\end{array}$ & $\begin{array}{c}0.0227 \\
(0.0199)\end{array}$ & $\begin{array}{c}0.0146 \\
(0.0165)\end{array}$ \\
\hline (2a) & IV - relative reform pressure & $\begin{array}{c}0.0026 \\
(0.0084)\end{array}$ & $\begin{array}{c}0.0112 \\
(0.0108)\end{array}$ & $\begin{array}{c}0.0227 \\
(0.0141)\end{array}$ & $\begin{array}{c}0.0396 \\
\underset{* \star * \star}{(0.0130)}\end{array}$ & $\begin{array}{c}0.0868 \\
\underset{* \star \star}{(0.0200)}\end{array}$ & $\begin{array}{c}0.1323 \\
\underset{* \star}{* \star}\end{array}$ & $\begin{array}{c}0.0183 \\
(0.0153)\end{array}$ & $\begin{array}{c}0.0221 \\
(0.0195)\end{array}$ & $\begin{array}{c}0.0143 \\
(0.0161)\end{array}$ \\
\hline (3a) & Demand conditions & $\begin{array}{c}0.0010 \\
(0.0029)\end{array}$ & $\begin{array}{c}0.0082 \\
(0.0050)\end{array}$ & $\begin{array}{c}0.0158 \\
(0.0058) \\
\star \star \star \star\end{array}$ & $\begin{array}{c}0.0208 \\
\underset{* \star \star}{(0.0057)}\end{array}$ & $\begin{array}{c}0.0335 \\
\underset{* * *}{(0.0093)}\end{array}$ & $\begin{array}{c}0.0401 \\
\underset{* \star *}{(0.0135)}\end{array}$ & $\begin{array}{c}0.0095 \\
(0.0051) \\
*\end{array}$ & $\begin{array}{c}0.0170 \\
(0.0076) \\
\star \star\end{array}$ & $\begin{array}{c}0.0259 \\
(0.0110) \\
\star \star\end{array}$ \\
\hline (4a) & Firm fixed effects & $\begin{array}{c}0.0017 \\
(0.0043)\end{array}$ & $\begin{array}{c}0.0075 \\
(0.0079)\end{array}$ & $\begin{array}{c}0.0148 \\
(0.0098)\end{array}$ & $\begin{array}{c}0.0252 \\
(0.0064) \\
\star \star \star\end{array}$ & $\begin{array}{c}0.0380 \\
(0.0081) \\
\star \star \star\end{array}$ & $\begin{array}{c}0.0496 \\
(0.0117) \\
\star \star \star\end{array}$ & $\begin{array}{c}0.0098 \\
(0.0054) \\
*\end{array}$ & $\begin{array}{c}0.0134 \\
(0.0077) \\
*\end{array}$ & $\begin{array}{c}0.0140 \\
(0.0105)\end{array}$ \\
\hline (5a) & Employment weights & $\begin{array}{c}0.0415 \\
(0.0193) \\
* \star\end{array}$ & $\begin{array}{c}0.0470 \\
(0.0257) \\
*\end{array}$ & $\begin{array}{c}0.0941 \\
\underset{*}{(0.0320)} \\
* * *\end{array}$ & $\begin{array}{c}0.0423 \\
(0.0239) \\
*\end{array}$ & $\begin{array}{c}0.0922 \\
\underset{* \star * \star}{(0.0340)}\end{array}$ & $\begin{array}{c}0.1216 \\
\underset{* \star * \star}{(0.0395)}\end{array}$ & $\begin{array}{c}0.0445 \\
(0.0194) \\
* \star\end{array}$ & $\begin{array}{c}0.0619 \\
(0.0267) \\
* *\end{array}$ & $\begin{array}{c}0.1207 \\
(0.0352) \\
* * *\end{array}$ \\
\hline (6a) & $\begin{array}{c}\text { Falsification test } \\
\text { - reforms at } t+3\end{array}$ & $\begin{array}{l}-0.0014 \\
(0.0020)\end{array}$ & $\begin{array}{l}-0.0031 \\
(0.0024)\end{array}$ & $\begin{array}{c}0.0023 \\
(0.0040)\end{array}$ & $\begin{array}{c}0.0171 \\
(0.0122)\end{array}$ & $\begin{array}{c}0.0180 \\
(0.0158)\end{array}$ & $\begin{array}{c}0.0198 \\
(0.0181)\end{array}$ & $\begin{array}{l}-0.0018 \\
(0.0048)\end{array}$ & $\begin{array}{c}0.0114 \\
\underset{* *}{(0.0046)}\end{array}$ & $\begin{array}{c}0.0195 \\
(0.0071) \\
* \star \star\end{array}$ \\
\hline \multicolumn{11}{|c|}{ Entry barriers } \\
\hline (1b) & IV - absolute reform pressure & $\begin{array}{l}0.0034 \\
(0.0130)\end{array}$ & $\begin{array}{c}0.0136 \\
(0.0185)\end{array}$ & $\begin{array}{c}0.0325 \\
(0.0246)\end{array}$ & $\begin{array}{c}0.0529 \\
(0.0192) \\
* \star \star\end{array}$ & $\begin{array}{c}0.1166 \\
\underset{* \star * \star}{(0.0311)}\end{array}$ & $\begin{array}{c}0.1816 \\
\underset{* \star \star}{(0.0441)}\end{array}$ & $\begin{array}{c}0.0295 \\
(0.0248)\end{array}$ & $\begin{array}{c}0.0427 \\
(0.0342)\end{array}$ & $\begin{array}{c}0.0307 \\
(0.0309)\end{array}$ \\
\hline (2b) & IV - relative reform pressure & $\begin{array}{c}0.0044 \\
(0.0128)\end{array}$ & $\begin{array}{c}0.0157 \\
(0.0180)\end{array}$ & $\begin{array}{c}0.0336 \\
(0.0243)\end{array}$ & $\begin{array}{c}0.0540 \\
\underset{* * *}{(0.0193)}\end{array}$ & $\begin{array}{c}0.1186 \\
\underset{* \star \star}{(0.0310)}\end{array}$ & $\begin{array}{c}0.1842 \\
\underset{* \star \star}{(0.0441)}\end{array}$ & $\begin{array}{c}0.0281 \\
(0.0247)\end{array}$ & $\begin{array}{c}0.0420 \\
(0.0339)\end{array}$ & $\begin{array}{c}0.0302 \\
(0.0303)\end{array}$ \\
\hline (3b) & Demand conditions & $\begin{array}{l}-0.0015 \\
(0.0036)\end{array}$ & $\begin{array}{c}0.0051 \\
(0.0063)\end{array}$ & $\begin{array}{c}0.0122 \\
(0.0072) \\
*\end{array}$ & $\begin{array}{c}0.0250 \\
(0.0064) \\
\star \star \star\end{array}$ & $\begin{array}{c}0.0325 \\
\underset{* \star \star}{(0.0117)}\end{array}$ & $\begin{array}{c}0.0399 \\
\underset{* \star}{(0.0164)}\end{array}$ & $\begin{array}{c}0.0146 \\
(0.0058) \\
\star \star\end{array}$ & $\begin{array}{c}0.0244 \\
(0.0088) \\
\star \star \star\end{array}$ & $\begin{array}{c}0.0331 \\
(0.0129) \\
\star \star\end{array}$ \\
\hline (4b) & Firm fixed effects & $\begin{array}{c}0.0011 \\
(0.0051)\end{array}$ & $\begin{array}{c}0.0077 \\
(0.0098)\end{array}$ & $\begin{array}{c}0.0168 \\
(0.0129)\end{array}$ & $\begin{array}{c}0.0272 \\
\underset{* \star * \star}{(0.0067)}\end{array}$ & $\begin{array}{c}0.0354 \\
\underset{* \star \star}{(0.0096)}\end{array}$ & $\begin{array}{c}0.0488 \\
\underset{* \star \star}{* \star 0141)}\end{array}$ & $\begin{array}{c}0.0136 \\
\underset{* *}{(0.0065)}\end{array}$ & $\begin{array}{c}0.0197 \\
(0.0104) \\
*\end{array}$ & $\begin{array}{c}0.0163 \\
(0.0147)\end{array}$ \\
\hline (5b) & Employment weights & $\begin{array}{c}0.0502 \\
(0.0213) \\
\star \star\end{array}$ & $\begin{array}{c}0.0252 \\
(0.0373)\end{array}$ & $\begin{array}{c}0.0590 \\
(0.0318) \\
*\end{array}$ & $\begin{array}{c}0.0390 \\
(0.0207) \\
*\end{array}$ & $\begin{array}{c}0.0762 \\
\underset{* \star}{(0.0318)}\end{array}$ & $\begin{array}{c}0.1027 \\
\underset{* \star * \star}{(0.0315)}\end{array}$ & $\begin{array}{c}0.0286 \\
(0.0234)\end{array}$ & $\begin{array}{c}0.0436 \\
(0.0382)\end{array}$ & $\begin{array}{c}0.0665 \\
(0.0472)\end{array}$ \\
\hline (6b) & $\begin{array}{l}\text { Falsification test } \\
\text { - reforms at } t+3\end{array}$ & $\begin{array}{l}-0.0016 \\
(0.0023)\end{array}$ & $\begin{array}{l}-0.0041 \\
(0.0027)\end{array}$ & $\begin{array}{c}0.0024 \\
(0.0038)\end{array}$ & $\begin{array}{c}0.0195 \\
(0.0136)\end{array}$ & $\begin{array}{c}0.0232 \\
(0.0157)\end{array}$ & $\begin{array}{c}0.0204 \\
(0.0171)\end{array}$ & $\begin{array}{c}0.0021 \\
(0.0052)\end{array}$ & $\begin{array}{c}0.0127 \\
(0.0048)\end{array}$ & $\begin{array}{c}0.0137 \\
(0.0062)\end{array}$ \\
\hline
\end{tabular}

Note: Regressions control for reforms in the previous and subsequent two years, include firm-level controls, as well as country-industry dummies, country-year dummies and industry-year dummies. Standard errors are robust and clustered by country and industry. ${ }^{*},{ }^{* *},{ }^{* * *}$ refer to statistical significance levels of $10 \%, 5 \%$ and $1 \%$ respectively.

\section{The heterogeneous effects of product market reforms across firms and sectors}

While the analysis so far focused on the response of the typical firm to product market reforms, the main value of using firm-level data is to analyse how the response differs across different types of firms and, by doing so, advantage describe the mechanisms through which product market reforms operate. In particular, depending on the production technology, and the nature of regulations, and the resulting 
market structure, the effects of deregulation are likely to differ across different types of firms. This section explores this issue by focusing on the role of industry and firm size.

\subsection{Results by sector}

As a first step to understanding the role of production technology and the nature of regulations for the impact of product market reforms, the analysis is conducted separately for each broad sector: network industries, retail trade and professional services. The results are reported in Table 7.

Table 7. The short-term effects of product market reforms by industry

$\%$ change in the outcome variable of interest in years after a major reform, selected coefficients

\begin{tabular}{|c|c|c|c|c|c|c|c|c|c|c|}
\hline & & \multicolumn{3}{|c|}{ Network } & \multicolumn{3}{|c|}{ Retail } & \multicolumn{3}{|c|}{ Professional services } \\
\hline & & $t=0$ & $t=1$ & $t=2$ & $t=0$ & $t=1$ & $t=2$ & $t=0$ & $t=1$ & $t=2$ \\
\hline \multicolumn{11}{|c|}{ Overall indicator (R1) } \\
\hline (1a) & Log employment (L) & $\begin{array}{c}0.0026 \\
(0.0051)\end{array}$ & $\begin{array}{c}0.0084 \\
(0.0092)\end{array}$ & $\begin{array}{c}0.0198 \\
(0.0101) \\
*\end{array}$ & $\begin{array}{c}0.0040 \\
(0.0037)\end{array}$ & $\begin{array}{c}0.0106 \\
(0.0083)\end{array}$ & $\begin{array}{c}0.0161 \\
(0.0119)\end{array}$ & $\begin{array}{c}0.0012 \\
(0.0050)\end{array}$ & $\begin{array}{c}0.0088 \\
(0.0078)\end{array}$ & $\begin{array}{c}0.0228 \\
(0.0086) \\
* \star\end{array}$ \\
\hline & $\mathrm{N}$ & 163,986 & 163,986 & 163,986 & 467,381 & 467,381 & 467,381 & 145,533 & 145,533 & 145,533 \\
\hline (2a) & Log capital (K) & $\begin{array}{c}0.0107 \\
(0.0059) \\
*\end{array}$ & $\begin{array}{c}0.0412 \\
\underset{* * *}{(0.0101)}\end{array}$ & $\begin{array}{c}0.0592 \\
(0.0158) \\
* \star \star\end{array}$ & $\begin{array}{c}0.0314 \\
(0.0097) \\
* * \star\end{array}$ & $\begin{array}{c}0.0417 \\
\underset{\star *}{(0.0152)}\end{array}$ & $\begin{array}{c}0.0512 \\
(0.0168) \\
\star \star \star\end{array}$ & $\begin{array}{c}0.0298 \\
(0.0120) \\
\star *\end{array}$ & $\begin{array}{c}0.0217 \\
(0.0254)\end{array}$ & $\begin{array}{c}0.0155 \\
(0.0364)\end{array}$ \\
\hline & $\mathrm{N}$ & 131,028 & 131,028 & 131,028 & 362,366 & 362,366 & 362,366 & 117,807 & 117,807 & 117,807 \\
\hline (3a) & Log output (Y) & $\begin{array}{c}0.0182 \\
\underset{\star *}{(0.0081)}\end{array}$ & $\begin{array}{c}0.0283 \\
(0.0119) \\
\star \star\end{array}$ & $\begin{array}{c}0.0293 \\
(0.0152) \\
*\end{array}$ & $\begin{array}{c}0.0152 \\
\underset{* \star}{(0.0054)}\end{array}$ & $\begin{array}{c}0.0292 \\
\underset{* \star 0}{(0.005)}\end{array}$ & $\begin{array}{c}0.0480 \\
(0.0184) \\
\star \star\end{array}$ & $\begin{array}{c}0.0082 \\
(0.0139)\end{array}$ & $\begin{array}{c}0.0366 \\
\underset{* \star}{(0.0126)}\end{array}$ & $\begin{array}{c}0.0816 \\
(0.0195) \\
\star \star \star \star\end{array}$ \\
\hline & $\mathrm{N}$ & 163,986 & 163,986 & 163,986 & 467,381 & 467,381 & 467,381 & 145,533 & 145,533 & 145,533 \\
\hline \multicolumn{11}{|c|}{ Entry indicator (R1) } \\
\hline (1b) & Log employment (L) & $\begin{array}{c}0.0018 \\
(0.0069)\end{array}$ & $\begin{array}{c}0.0084 \\
(0.0124)\end{array}$ & $\begin{array}{c}0.0201 \\
(0.0131)\end{array}$ & $\begin{array}{c}0.0021 \\
(0.0036)\end{array}$ & $\begin{array}{c}0.0098 \\
(0.0087)\end{array}$ & $\begin{array}{c}0.0183 \\
(0.0113)\end{array}$ & $\begin{array}{c}-0.0012 \\
(0.0051)\end{array}$ & $\begin{array}{c}0.0054 \\
(0.0083)\end{array}$ & $\begin{array}{c}0.0188 \\
(0.0099) \\
*\end{array}$ \\
\hline & $\mathrm{N}$ & 163,882 & 163,882 & 163,882 & 466,054 & 466,054 & 466,054 & 149,801 & 149,801 & 149,801 \\
\hline (2b) & Log capital (K) & $\begin{array}{c}0.0164 \\
(0.0072) \\
\star \star\end{array}$ & $\begin{array}{c}0.0436 \\
(0.0137) \\
* \star \star\end{array}$ & $\begin{array}{c}0.0639 \\
(0.0193) \\
* \star \star\end{array}$ & $\begin{array}{c}0.0300 \\
(0.0110) \\
\star \star\end{array}$ & $\begin{array}{c}0.0410 \\
(0.0184) \\
\star *\end{array}$ & $\begin{array}{c}0.0527 \\
\underset{* \star}{(0.0217)}\end{array}$ & $\begin{array}{c}0.0355 \\
(0.0106) \\
\star \star \star\end{array}$ & $\begin{array}{c}0.0291 \\
(0.0236)\end{array}$ & $\begin{array}{c}0.0303 \\
(0.0328)\end{array}$ \\
\hline & N & 130,925 & 130,925 & 130,925 & 361,168 & 361,168 & 361,168 & 121,957 & 121,957 & 121,957 \\
\hline (3b) & Log output (Y) & $\begin{array}{c}0.0250 \\
(0.0100) \\
\star \star\end{array}$ & $\begin{array}{c}0.0390 \\
(0.0155) \\
\star \star\end{array}$ & $\begin{array}{c}0.0365 \\
(0.0201) \\
*\end{array}$ & $\begin{array}{c}0.0180 \\
(0.0046) \\
* * \star\end{array}$ & $\begin{array}{c}0.0381 \\
(0.0078) \\
\star * \star\end{array}$ & $\begin{array}{c}0.0583 \\
\underset{* *}{(0.0211)}\end{array}$ & $\begin{array}{c}0.0097 \\
(0.0147)\end{array}$ & $\begin{array}{c}0.0357 \\
\underset{* *}{(0.0139)}\end{array}$ & $\begin{array}{c}0.0725 \\
(0.0210) \\
\star \star \star \star\end{array}$ \\
\hline & $\mathrm{N}$ & 163,882 & 163,882 & 163,882 & 466,054 & 466,054 & 466,054 & 149,801 & 149,801 & 149,801 \\
\hline
\end{tabular}

Note: Regressions control for reforms in the previous and subsequent two years, include firm-level controls, as well as countryindustry dummies, country-year dummies and industry-year dummies. Standard errors are robust and clustered by country and industry. ${ }^{*},{ }^{* *},{ }^{* * *}$ refer to statistical significance levels of $10 \%, 5 \%$ and $1 \%$ respectively.

First, the impact of product market reforms is typically positive and increasing in each of the broad sectors and for each of the outcome variables outcomes. Second, while most reform activity during the sample period was concentrated in network industries, the returns to reforms in terms of output appear to be similar or even larger in retail trade and professional services. This implies that there may not only be considerable scope but also substantial benefits to making further pro-competitive reforms in those sectors. Third, the impact of product market reforms on investment is concentrated in network industries and 
retail. ${ }^{36}$ Fourth, the role of reductions in the overall restrictiveness of product market regulation and that in barriers to entry tend to be rather similar in each of the three sectors (Panel B).

\subsection{Results by firm size}

In order to shed light on the mechanisms through which the effects of product market reforms operate in each sector, this sub-section analyses their effects across firms of different sizes. The results, summarised in Table 8, reveal important differences within each sector. Figure 5 visualises the results for employment by focusing on firms with less than 20 employees and those with 20 or more employees. ${ }^{37}$

In network industries, the impact of product market deregulation on employment is positive for small firms, but negative, if anything, for large firms. For investment, a similar pattern is observed, with a positive impact on small firms and no significant impact on large firms. Interestingly, reforms have a positive impact on output, but there are no significant differences across size groups. This suggests that large firms are able to maintain their market share by restructuring employment and downscaling investment plans. A very different picture is observed for the retail sector. Product market deregulation in retail has a positive impact on employment and investment among large firms, but no significant effect on small firms. At the same time, deregulation has no significant effect on output for any size group. The absence of a more positive effect on output among large firms, despite positive effects on employment and investment, may indicate that increases in production scale are associated with market-share preserving output price declines. ${ }^{38}$ Size differences do not play much of a role in professional services.

The heterogeneous response of different firms to deregulation between network industries, on the one hand, and the retail sector on the other, highlights important differences in the underlying mechanisms that drive the effects of product market reforms. Network industries tend to be dominated by a small number of large firms with considerable market power. In order to maintain their market share in the threat of entry, incumbents have a tendency to reduce their production costs by cutting back employment and investment plans. Consistent with this narrative, the results in Table A9 in Annex A4 show that the heterogeneous response by firm size to reductions in entry barriers is even more pronounced than in the case of reductions in the overall restrictiveness of product market regulation. By contrast, in retail small traditionally-managed firms do not benefit from deregulation or even leave the market while large and

36. The relative importance of product market reforms for investment in network industries is likely to reflect their relatively capital-intensive production technologies. Their importance for investment in retail may seem surprising given the generally lower level of capital intensity. However, this is likely to reflect the positive impact on large firms which tend to be more capital-intensive (see Table 8).

37. The role of firm age was also considered, and. young network industry firms found to be significantly more positively affected, whereas in the retail sector firms react more strongly when they are more mature (at least 10 years old). Given that there is a strong relationship between size and age, and the pattern is consistent with the mechanism we describe when comparing effects across firm-sizes. (see Annex Tables A9 and A10).

38. Differences in real output across firms within countries and industries reflect both prices and quantities, as price deflators are only available at country-industry level. For this reason, output developments across firms within sectors should be interpreted as changes in the market shares. 
Figure 5. The short-term effects of product market reforms on incumbent firms

Percentage change in employment in years after the reform

Panel A. Network industries

Small firms (<20 employees) Large firms ( $>=20$ employees $)$
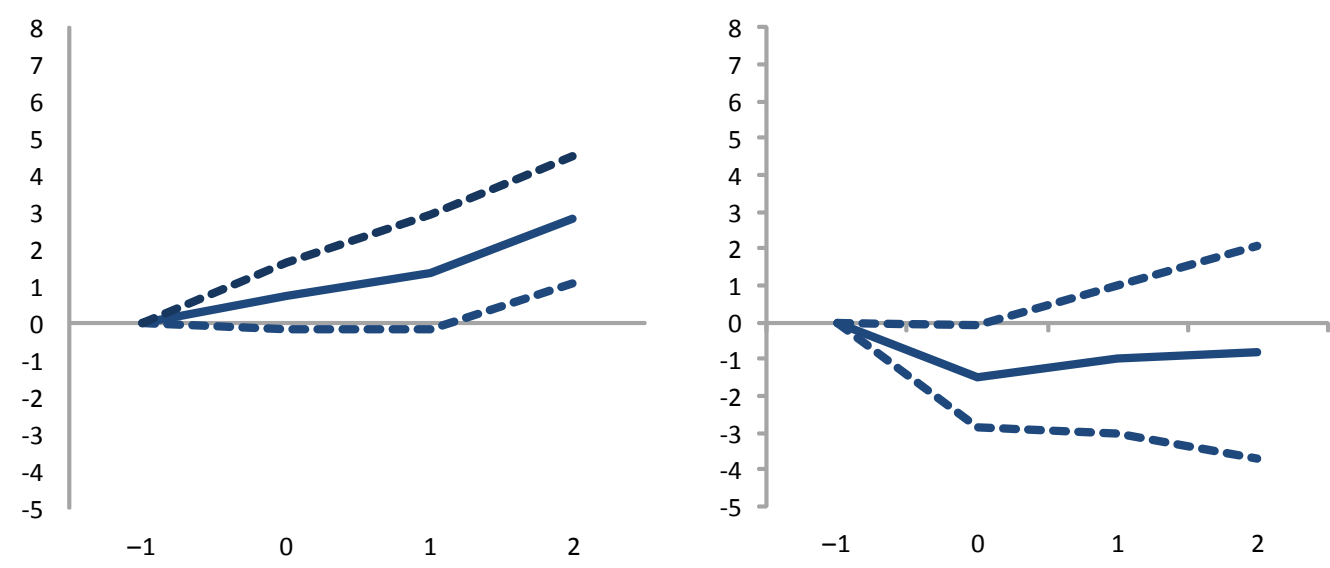

Panel B. Retail trade

Small firms ( $<20$ employees $)$

Large firms (>= 20 employees)
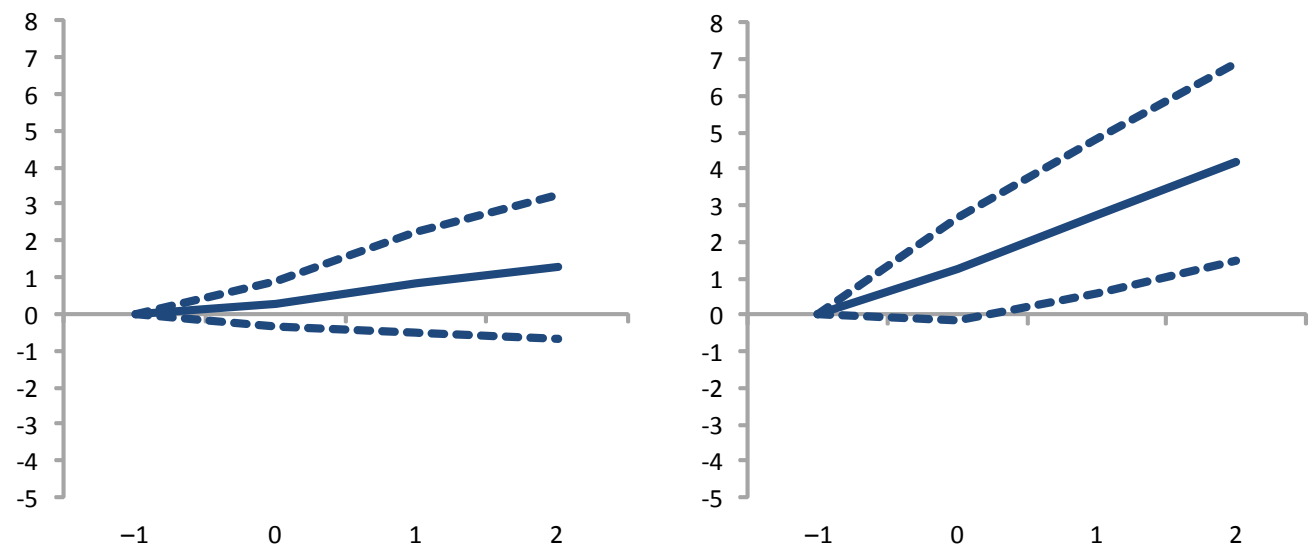

Note: Dashed lines represent $90 \%$ confidence intervals

typically more modern firms expand their activities further. ${ }^{39}$ The heterogeneous response to reductions in the overall restrictiveness in product market regulation is similar or more pronounced than that to reductions in entry barriers, which suggests that the threat of entry plays a less important role for the heterogeneous response of firms to deregulation in retail than in network industries. The finding that employment in large network firms responds negatively to liberalisation in the short run is consistent with the recent industry-level results in Bassanini (2015) and OECD (2016).

39. The size differences are likely to be understated since many of the small firms that cannot keep up with the competition shut down. 


\section{Table 8. The short-term effects of product market reforms by industry and firm size}

$\%$ change in the outcome variable of interest in years after a major reduction in the overall restrictiveness of product market regulation, selected coefficients

\begin{tabular}{|c|c|c|c|c|c|c|c|c|c|c|}
\hline & & \multicolumn{2}{|c|}{ Network industries } & \multicolumn{3}{|c|}{ Retail } & \multicolumn{4}{|c|}{ Professional services } \\
\hline & & $t=0$ & $t=1$ & $t=2$ & $t=0$ & $t=1$ & $t=2$ & $t=0$ & $t=1$ & $t=2$ \\
\hline \multicolumn{11}{|c|}{ Panel A. log employment (L) } \\
\hline (1a) & Base (small firms) & $\begin{array}{c}0.0175 \\
(0.0081) \\
\star \star\end{array}$ & $\begin{array}{c}0.0254 \\
\underset{* *}{(0.0109)}\end{array}$ & $\begin{array}{c}0.0426 \\
(0.0135) \\
\star \star \star\end{array}$ & $\begin{array}{c}0.0007 \\
(0.0046)\end{array}$ & $\begin{array}{c}0.0053 \\
(0.0091)\end{array}$ & $\begin{array}{c}0.0091 \\
(0.0130)\end{array}$ & $\begin{array}{l}-0.0132 \\
(0.0096)\end{array}$ & $\begin{array}{c}0.0013 \\
(0.0123)\end{array}$ & $\begin{array}{c}0.0085 \\
(0.0145)\end{array}$ \\
\hline (2a) & Medium-sized firms & $\begin{array}{c}-0.0392 \\
(0.0178) \\
\star \star\end{array}$ & $\begin{array}{c}-0.0449 \\
(0.0152) \\
\star \star \star\end{array}$ & $\begin{array}{c}-0.0571 \\
(0.0182) \\
\star \star \star \star\end{array}$ & $\begin{array}{c}0.0147 \\
(0.0098)\end{array}$ & $\begin{array}{c}0.0223 \\
(0.0129) \\
*\end{array}$ & $\begin{array}{c}0.0272 \\
(0.0168)\end{array}$ & $\begin{array}{c}0.0865 \\
(0.0738)\end{array}$ & $\begin{array}{c}0.0625 \\
(0.0864)\end{array}$ & $\begin{array}{c}0.1270 \\
(0.1060)\end{array}$ \\
\hline \multirow[t]{3}{*}{ (3a) } & Large firms & $\begin{array}{c}-0.0351 \\
(0.0092) \\
\star \star \star *\end{array}$ & $\begin{array}{c}-0.0394 \\
(0.0099) \\
* * \star\end{array}$ & $\begin{array}{c}-0.0560 \\
(0.0190) \\
* * \star\end{array}$ & $\begin{array}{c}0.0151 \\
(0.0110)\end{array}$ & $\begin{array}{c}0.0268 \\
(0.0154) \\
*\end{array}$ & $\begin{array}{c}0.0401 \\
(0.0191) \\
*\end{array}$ & $\begin{array}{c}0.0476 \\
(0.0677)\end{array}$ & $\begin{array}{c}-0.0077 \\
(0.0782)\end{array}$ & $\begin{array}{c}-0.0304 \\
(0.1107)\end{array}$ \\
\hline & $\mathrm{N}$ & 163,986 & 163,986 & 163,986 & 467,381 & 467,381 & 467,381 & 145,533 & 145,533 & 145,533 \\
\hline & \multicolumn{10}{|c|}{ Panel B. log capital (K) } \\
\hline (1a) & Base (small firms) & $\begin{array}{c}0.0141 \\
(0.0063) \\
\star \star\end{array}$ & $\begin{array}{c}0.0510 \\
(0.0113) \\
\star \star \star\end{array}$ & $\begin{array}{c}0.0781 \\
(0.0186) \\
\star \star \star \star\end{array}$ & $\begin{array}{c}0.0262 \\
(0.0103) \\
\star \star\end{array}$ & $\begin{array}{c}0.0353 \\
(0.0156) \\
\star \star\end{array}$ & $\begin{array}{c}0.0412 \\
(0.0166) \\
\star *\end{array}$ & $\begin{array}{c}0.0310 \\
(0.0221)\end{array}$ & $\begin{array}{c}-0.0014 \\
(0.0366)\end{array}$ & $\begin{array}{l}-0.0532 \\
(0.0510)\end{array}$ \\
\hline (2a) & Medium-sized firms & $\begin{array}{l}-0.0146 \\
(0.0159)\end{array}$ & $\begin{array}{c}-0.0145 \\
(0.0219)\end{array}$ & $\begin{array}{l}-0.0320 \\
(0.0242)\end{array}$ & $\begin{array}{c}0.0236 \\
(0.0038) \\
\star \star \star\end{array}$ & $\begin{array}{c}0.0213 \\
(0.0058) \\
\star \star \star\end{array}$ & $\begin{array}{c}0.0330 \\
(0.0094) \\
\star \star \star\end{array}$ & $\begin{array}{l}-0.0812 \\
(0.1563)\end{array}$ & $\begin{array}{c}0.0645 \\
(0.2114)\end{array}$ & $\begin{array}{c}0.3541 \\
(0.2703)\end{array}$ \\
\hline \multirow[t]{3}{*}{ (3a) } & Large firms & $\begin{array}{l}-0.0025 \\
(0.0134)\end{array}$ & $\begin{array}{l}-0.0353 \\
(0.0270)\end{array}$ & $\begin{array}{l}-0.0638 \\
(0.0410)\end{array}$ & $\begin{array}{c}0.0244 \\
(0.0071) \\
\star \star \star *\end{array}$ & $\begin{array}{c}0.0428 \\
(0.0125) \\
\star \star \star *\end{array}$ & $\begin{array}{c}0.0646 \\
(0.0192) \\
\star \star \star \star\end{array}$ & $\begin{array}{c}0.1425 \\
(0.1273)\end{array}$ & $\begin{array}{c}0.2310 \\
(0.1962)\end{array}$ & $\begin{array}{c}0.3427 \\
(0.2228)\end{array}$ \\
\hline & $\mathrm{N}$ & 131,028 & 131,028 & 131,028 & 362,366 & 362,366 & 362,366 & 117,807 & 117,807 & 117,807 \\
\hline & \multicolumn{10}{|c|}{ Panel C. log sales (Y) } \\
\hline (1a) & Base (small firms) & $\begin{array}{c}0.0192 \\
(0.0099) \\
*\end{array}$ & $\begin{array}{c}0.0301 \\
(0.0124) \\
\star \star\end{array}$ & $\begin{array}{c}0.0276 \\
(0.0120) \\
\star \star\end{array}$ & $\begin{array}{c}0.0140 \\
(0.0052) \\
\star \star\end{array}$ & $\begin{array}{c}0.0292 \\
(0.0101) \\
\star \star \star\end{array}$ & $\begin{array}{c}0.0488 \\
(0.0193) \\
\star \star\end{array}$ & $\begin{array}{l}-0.0259 \\
(0.0267)\end{array}$ & $\begin{array}{c}0.0129 \\
(0.0220)\end{array}$ & $\begin{array}{c}0.0698 \\
(0.0301) \\
\star *\end{array}$ \\
\hline (2a) & Medium-sized firms & $\begin{array}{l}-0.0119 \\
(0.0104)\end{array}$ & $\begin{array}{l}-0.0147 \\
(0.0119)\end{array}$ & $\begin{array}{c}-0.0061 \\
(0.0139)\end{array}$ & $\begin{array}{c}0.0018 \\
(0.0054)\end{array}$ & $\begin{array}{l}-0.0008 \\
(0.0060)\end{array}$ & $\begin{array}{l}-0.0055 \\
(0.0062)\end{array}$ & $\begin{array}{c}0.1857 \\
(0.1569)\end{array}$ & $\begin{array}{c}0.1842 \\
(0.1171)\end{array}$ & $\begin{array}{c}0.0675 \\
(0.1308)\end{array}$ \\
\hline (3a) & Large firms & $\begin{array}{c}0.0066 \\
(0.0121)\end{array}$ & $\begin{array}{c}0.0053 \\
(0.0166)\end{array}$ & $\begin{array}{c}0.0136 \\
(0.0240)\end{array}$ & $\begin{array}{c}0.0112 \\
(0.0044) \\
\star \star\end{array}$ & $\begin{array}{c}0.0018 \\
(0.0115)\end{array}$ & $\begin{array}{l}-0.0001 \\
(0.0187)\end{array}$ & $\begin{array}{c}0.1469 \\
(0.0924)\end{array}$ & $\begin{array}{c}0.0014 \\
(0.0882)\end{array}$ & $\begin{array}{c}0.0413 \\
(0.1138)\end{array}$ \\
\hline & $\mathrm{N}$ & 163,986 & 163,986 & 163,986 & 467,381 & 467,381 & 467,381 & 145,533 & 145,533 & 145,533 \\
\hline
\end{tabular}

Note: Regressions control for reforms in the previous and subsequent two years, include firm-level controls, as well as countryindustry dummies, country-year dummies and industry-year dummies. Standard errors are robust and clustered by country and industry. ${ }^{*},{ }^{* *},{ }^{* * *}$ refer to statistical significance levels of $10 \%, 5 \%$ and $1 \%$ respectively. Small, medium and large firms are defined as having 3-9 10-19 and 20+ employees, respectively, in year t-1.

\subsection{Results for firm entry}

While differentiating by firm size may give some indication of the impact of reforms on insiders versus outsiders, a proper analysis of this issue requires examining their impact on entry and exit. Unfortunately, this is not straightforward with the present data since the large majority of firms that appear in or disappear from the Orbis sample may not enter or exit the market in reality due to variations in coverage over time. Since this issue can be more easily circumvented for entry than for exit - by using the 
incorporation date of companies - the analysis in this sub-section will concentrate on entry only. The main reason for this is that in the case of exit we largely have to rely on the appearance pattern of firms in the data whereas this is not the case for entry as is explained below. ${ }^{40}$

There are a number of problems that one has to overcome in order to analyse the effects of product market reforms on firm entry. First, firms only appear in the dataset with a lag, often many years after their actual date of incorporation. However, by making use of information provided in Orbis on the date of incorporation it is possible to extend the data backwards until the birth of each firm that at some point appears in the dataset. Importantly, this means that we do not have to rely on the appearance of firms in the data. ${ }^{41}$ Second, to define entry rates, i.e. the number of entrants over the number of incumbents in the previous period, one ideally needs to know the number of existing firms in each year which requires taking account of exit. We largely circumvent this problem by weighting entry rates by the average number of firms in each country and industry cell. This greatly reduces the sensitivity of the results to the definition of the denominator, as will be shown below. Third, entry rates may be subject to considerable measurement error due to changes in coverage in the data and small sample sizes. To mitigate these issues, we restrict the time window to the period 2000-2009, the period during which coverage is relatively stable, exclude country-industry observations associated with very large annual increases or decreases in the number of firms due to coverage changes in Orbis (changes larger than 1.5 or smaller than 0.67) and remove any observations with entry rates above $25 \%$ (about the top $1 \%$ ). Moreover, weighting also helps to reduce the sensitivity of entry rates to measurement error in the numerator due to small cell sizes.

We make use of three alternative measures of firm entry that make different assumptions on exit. First, we define the entry rate as the share of new entrants over the number of reporting firms in Orbis the previous year (narrow definition). The focus on reporting firms is not ideal as it does not take account of firms that do not report but remain active. In order to address this possibility we make use of a second measure of entry that uses all firms in the previous year that existed at some point, including firms that appear to have exited since (broad definition). Finally, we define entry in terms of the log number of entrants. To the extent that these measures yield similar results this alleviates concerns about the potentially confounding role of firm exit.

Table 9 reports the resulting entry rates by industry on average across countries and years (using both the narrow and the broad measure of the entry rate). Entry rates on average across countries and years are estimated to be about 5\%. Moreover, entry is relatively high in telecommunications and postal services, whereas it is relatively low in air and rail transport, in line with expectations. There is also some indication that entry rates decline over time (not shown). While this could be genuine consistent with evidence for the United States by Decker et al. (2014) and for 18 countries by Criscuolo et al. (2014), it is also likely to be driven by the definition of our entry measures due to the lag with which firms enter the data (this induces a trend decline in the numerator) and the increase in coverage over time (which induces a trend increase in the denominator). However, to the extent that this reflects increases over time in the coverage of Orbis (see

40. While Orbis provides information provides information on activity status this information is time-invariant (it is only supplied for the last reporting year). This means that in order to identify when the change in activity status took place one has to rely on the reporting pattern of firms in the data. This is far from ideal, particularly for more recent years, and explains why we cannot analyse the impact of product market reforms on firm exit with the present data.

41. It does however introduce some survivor bias as this procedure does not take account of firms that exit before they appear in the data. This means that descriptive statistics are likely to understate the importance of entry. For the econometric analysis, this is an issue only to the extent that survivor bias is correlated with product market reforms conditional on controls. We do not see a plausible argument for this a priori. 
Table 1) or a mechanical decline due to reporting lags, these will be largely controlled for in the empirical analysis through the use of our rich dummy structure and particularly the use of country-year dummies.

Table 9. Entry rates by industry

Average across countries and years, 2000-2009

\begin{tabular}{lcccc}
\hline & \multicolumn{2}{c}{ Narrow measure } & \multicolumn{2}{c}{ Broad measure } \\
& & & & \\
& Mean & St.dev. & Mean & St.dev. \\
\hline Electricity & 0.070 & 0.043 & 0.067 & 0.042 \\
Gas & 0.046 & 0.043 & 0.043 & 0.041 \\
Telecommunications & 0.080 & 0.042 & 0.071 & 0.043 \\
Postal senvices & 0.059 & 0.041 & 0.053 & 0.039 \\
Rail transport & 0.043 & 0.047 & 0.041 & 0.046 \\
Air transport & 0.042 & 0.035 & 0.038 & 0.033 \\
Road transport & 0.052 & 0.029 & 0.048 & 0.028 \\
Retail trade & 0.056 & 0.021 & 0.050 & 0.023 \\
Business services & 0.060 & 0.029 & 0.056 & 0.030 \\
Technical services & 0.063 & 0.030 & 0.055 & 0.031 \\
& & & & \\
Average & 0.057 & 0.036 & 0.052 & 0.036 \\
& & & & \\
\hline
\end{tabular}

Note: Averages are weighted by the average number of firms in country-industry cells.

In order to analyse the effects of product market reforms we estimate the same model we have used so far but at the sector and country level. Regressions are weighted by the average number of firms in each country-industry cell. The results indicate that product market reforms tend to promote entry and that its impact increases over the first two years (Table 10). The positive impact of product market reforms on entry is driven by retail and to a lesser extent network industries. Consistent with priors, the impact is considerably larger when focusing on reductions in entry barriers than in the case of reductions in the overall restrictiveness of product market regulations. The impact of product market reforms on entry is very similar across the two measures of entry, providing some reassurance that the results are not driven by idiosyncratic movements in the number of firms. The point estimates indicate the reforms increase firm entry by around one percentage point after two years.

The impact on entry for the overall economy is likely to be modest in the short-term since most new firms are likely to be small. However, its payoffs may be substantial in the longer-term. Of course, the positive effects of product market reforms on entry should be weighted against their potentially negative effects on exits. Firm exit is potentially more important for understanding the aggregate effects of product market reforms in the short-term since it may affect small and large firms alike. Unfortunately, this could not be analysed with the available data. However, note that the size of estimates in the firm-level analysis are close to the industry level estimates in Bouis et al. (2016), suggesting that the negative effects of exit do not overturn the positive effects of deregulation on incumbents firms who remain active as well as firm entry. 
Table 10. The short-term effects of product market reforms on firm entry

\begin{tabular}{|c|c|c|c|c|c|c|c|c|c|c|c|c|c|}
\hline & & \multicolumn{3}{|c|}{ All } & \multicolumn{3}{|c|}{ Network } & \multicolumn{3}{|c|}{ Retail } & \multicolumn{3}{|c|}{ Professional services } \\
\hline & & $t=0$ & $t=1$ & $t=2$ & $t=0$ & $t=1$ & $t=2$ & $t=0$ & $t=1$ & $t=2$ & $t=0$ & $t=1$ & $t=2$ \\
\hline \multicolumn{14}{|c|}{ Entry rate (narrow measure) } \\
\hline (1a) & Overall restrictiveness & $\begin{array}{c}0.0020 \\
(0.0021)\end{array}$ & $\begin{array}{c}0.0053 \\
\underset{\star \star}{(0.0024)}\end{array}$ & $\begin{array}{c}0.0076 \\
(0.0027) \\
\star \star \star \star\end{array}$ & $\begin{array}{c}0.0018 \\
(0.0027)\end{array}$ & $\begin{array}{c}0.0012 \\
(0.0031)\end{array}$ & $\begin{array}{c}0.0047 \\
(0.0034)\end{array}$ & $\begin{array}{c}0.0076 \\
(0.0043) \\
\star\end{array}$ & $\begin{array}{c}0.0162 \\
(0.0046) \\
\star \star \star \\
\end{array}$ & 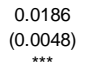 & $\begin{array}{l}-0.0061 \\
(0.0059)\end{array}$ & $\begin{array}{c}0.0037 \\
(0.0069)\end{array}$ & $\begin{array}{c}0.0020 \\
(0.0075)\end{array}$ \\
\hline (2a) & Entry barriers & $\begin{array}{c}0.0038 \\
(0.0029)\end{array}$ & $\begin{array}{c}0.0095 \\
\underset{\star \star \star \star}{(0.0034)}\end{array}$ & $\begin{array}{c}0.0114 \\
\underset{\star \star \star}{* \star 0037})\end{array}$ & $\begin{array}{c}0.0056 \\
(0.0038)\end{array}$ & $\begin{array}{c}0.0049 \\
(0.0046)\end{array}$ & $\begin{array}{c}0.0095 \\
(0.0050) \\
\star\end{array}$ & $\begin{array}{c}0.0069 \\
(0.0063)\end{array}$ & $\begin{array}{c}0.0184 \\
(0.0072) \\
\star \star\end{array}$ & $\begin{array}{c}0.0232 \\
\underset{\star \star \star \star}{(0.0077)}\end{array}$ & $\begin{array}{c}-0.0035 \\
(0.0066)\end{array}$ & $\begin{array}{c}0.0112 \\
(0.0069)\end{array}$ & $\begin{array}{c}0.0061 \\
(0.0075)\end{array}$ \\
\hline \multicolumn{14}{|c|}{ Entry rate (broad measure) } \\
\hline (1b) & Overall restrictiveness & $\begin{array}{c}0.0017 \\
(0.0021)\end{array}$ & $\begin{array}{c}0.0050 \\
\underset{\star \star}{(0.0024)}\end{array}$ & 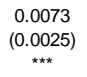 & $\begin{array}{c}0.0016 \\
(0.0026)\end{array}$ & $\begin{array}{c}0.0008 \\
(0.0030)\end{array}$ & $\begin{array}{c}0.0045 \\
(0.0032)\end{array}$ & $\begin{array}{c}0.0071 \\
(0.0042) \\
\star\end{array}$ & $\begin{array}{c}0.0158 \\
(0.0045) \\
\star \star \star \\
\end{array}$ & $\begin{array}{c}0.0181 \\
\underset{\star \star \star \star}{(0.0047)}\end{array}$ & $\begin{array}{c}-0.0064 \\
(0.0056)\end{array}$ & $\begin{array}{c}0.0040 \\
(0.0068)\end{array}$ & $\begin{array}{c}0.0015 \\
(0.0073)\end{array}$ \\
\hline & Entry barriers & $\begin{array}{c}0.0037 \\
(0.0028)\end{array}$ & $\begin{array}{c}0.0093 \\
(0.0033) \\
\star \star \star\end{array}$ & $\begin{array}{c}0.0117 \\
(0.0035) \\
\star \star \star\end{array}$ & $\begin{array}{c}0.0053 \\
(0.0037)\end{array}$ & $\begin{array}{c}0.0044 \\
(0.0044)\end{array}$ & $\begin{array}{c}0.0098 \\
\underset{\star \star \star}{(0.0047)}\end{array}$ & $\begin{array}{c}0.0067 \\
(0.0062)\end{array}$ & $\begin{array}{c}0.0180 \\
(0.0071) \\
\star \star\end{array}$ & $\begin{array}{c}0.0232 \\
(0.0075) \\
\star \star \star\end{array}$ & $\begin{array}{c}-0.0032 \\
(0.0063)\end{array}$ & $\begin{array}{c}0.0119 \\
(0.0068) \\
\star\end{array}$ & $\begin{array}{c}0.0067 \\
(0.0072)\end{array}$ \\
\hline \multicolumn{14}{|c|}{ Log entry } \\
\hline (1c) & Overall restrictiveness & $\begin{array}{c}0.0472 \\
(0.0317)\end{array}$ & $\begin{array}{c}0.0686 \\
(0.0363) \\
\star\end{array}$ & $\begin{array}{c}0.0911 \\
\underset{\star \star}{(0.0402)}\end{array}$ & $\begin{array}{c}0.0609 \\
(0.0408)\end{array}$ & $\begin{array}{c}0.0337 \\
(0.0487)\end{array}$ & $\begin{array}{c}0.0736 \\
(0.0542)\end{array}$ & $\begin{array}{c}0.0966 \\
(0.0540) \\
\star\end{array}$ & $\begin{array}{c}0.1789 \\
(0.0581) \\
\star \star \star \star \\
\end{array}$ & $\begin{array}{c}0.2043 \\
\underset{\star \star \star \star}{(0.0544)}\end{array}$ & $\begin{array}{c}-0.0865 \\
(0.0903)\end{array}$ & $\begin{array}{c}-0.0589 \\
(0.1015)\end{array}$ & $\begin{array}{c}-0.0373 \\
(0.1147)\end{array}$ \\
\hline (2c) & Entry barriers & $\begin{array}{c}0.0692 \\
(0.0393) \\
\star\end{array}$ & $\begin{array}{c}0.1277 \\
\underset{\star \star \star \star}{(0.0454)}\end{array}$ & $\begin{array}{c}0.1554 \\
\underset{* \star \star}{(0.0502)}\end{array}$ & $\begin{array}{c}0.1152 \\
(0.0530) \\
\star \star\end{array}$ & $\begin{array}{c}0.1070 \\
(0.0641) \\
*\end{array}$ & $\begin{array}{c}0.1631 \\
\underset{* \star}{(0.0713)}\end{array}$ & $\begin{array}{c}0.0808 \\
(0.0670)\end{array}$ & $\begin{array}{c}0.1794 \\
(0.0736) \\
\star \star\end{array}$ & $\begin{array}{c}0.2149 \\
\underset{* \star \star}{(0.0725)}\end{array}$ & $\begin{array}{c}-0.0540 \\
(0.0993)\end{array}$ & $\begin{array}{c}0.0919 \\
(0.1044)\end{array}$ & $\begin{array}{c}0.0949 \\
(0.1147)\end{array}$ \\
\hline & $\mathrm{N}$ & 925 & 925 & 925 & 681 & 681 & 681 & 92 & 92 & 92 & 152 & 152 & 152 \\
\hline
\end{tabular}

Note: Regressions include controls for reforms in the previous and subsequent two years as well as country-industry dummies, country-year dummies and industry-year dummies. Standard errors are robust and clustered by country and industry. ${ }^{*},{ }^{* *},{ }^{* * *}$ refer to statistical significance levels of $10 \%, 5 \%$ and $1 \%$ respectively.

\section{Product market reforms, financial frictions and investment}

As was shown above, product market reforms have the potential of importantly boosting investment by firms. Against the background of persistently weak corporate and bank balance sheets in many parts of Europe, an important question is whether the impact of product market reforms on investment could be muted by tight credit conditions. If credit conditions are important determinants of the short-term effects of product market reforms, this provides an additional argument for strengthening corporate and bank balance sheets.

\subsection{A first take focusing on the indebtedness across firms}

As a first step to addressing this question, the role of indebtedness is analysed by differentiating between firms with no debt, low debt (relative to total assets) and high debt. ${ }^{42}$ In an effort to isolate the role of credit constraints that may be associated with high levels of indebtedness from the confounding role of credit demand average debt ratios over time are used. The results suggest that credit constraints may be important (Table 11). The short-term impact of product market reforms on investment among firms

42. Indebtedness is measured as the sum of long and short-term debt divided by total assets. 
without any debt is about $7 \%$ after two years, whereas it is not statistically different from zero for firms with high debt-to-asset ratios. ${ }^{43}$

Figure 6. The role of indebtedness for the short-term effects of product market reforms on investment

Percentage change in the capital stock in years after the reform
No debt
B. Some debt
C. High debt
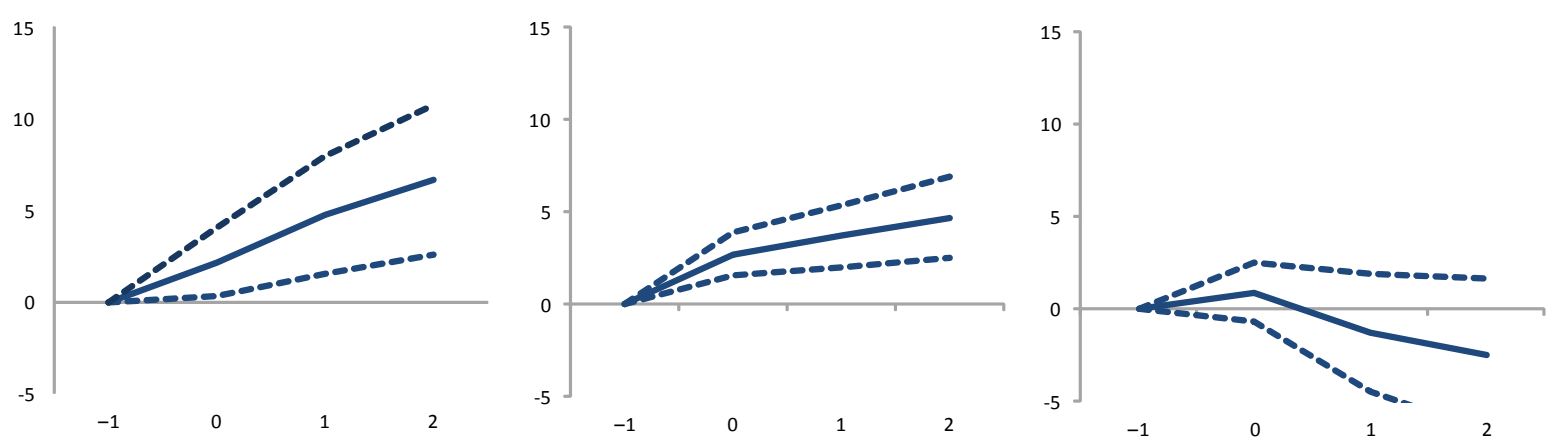

Note: Dashed lines represent $90 \%$ confidence intervals. Some debt: strictly positive debt-to-asset ratio of less than 0.25 ; high debt: debt-to-asset ratio of 0.25 or more.

While these results may reflect the role of credit constraints among highly indebted firms, it is also possible that indebtedness captures high credit demand and the availability of profitable investment opportunities and this may be associated with differences in the responsiveness of investment to product market reforms, irrespective of prevailing credit conditions. However, this is not very plausible as such firms are likely to have a higher responsiveness of investment to product market reforms rather than a lower one as the findings suggest. It may be possible, however, that debt is used as a means for firms in poor financial health to keep themselves afloat. This would most likely be reflected by a lower responsiveness of investment to product market reforms, consistent with the results, but does not hinge on the nature of credit conditions per se.

43. The effects broadly hold within each broad sector, suggesting that it is not the intrinsic cross-sector differences in average sector-level indebtedness that drive the results, but instead within-sector differences across firms. 
ECO/WKP(2016)35

Table 11. The short-term effects of product market reforms on investment by industry and debt category

\begin{tabular}{|c|c|c|c|c|c|c|c|c|c|c|c|c|c|}
\hline & & \multicolumn{3}{|c|}{ All industries } & \multicolumn{3}{|c|}{ Network industries } & \multicolumn{3}{|l|}{ Retail } & \multicolumn{3}{|c|}{ Professional services } \\
\hline & & $t=0$ & $t=1$ & $t=2$ & $t=0$ & $t=1$ & $t=2$ & $t=0$ & $t=1$ & $t=2$ & $t=0$ & $t=1$ & $t=2$ \\
\hline & \multicolumn{13}{|c|}{ Overall restrictiveness of product market regulation } \\
\hline (1a) & Base (no debt) & $\begin{array}{c}0.0208 \\
(0.0119) \\
*\end{array}$ & $\begin{array}{c}0.0536 \\
(0.0207) \\
* *\end{array}$ & $\begin{array}{c}0.0730 \\
\underset{\star \star \star}{(0.0242)}\end{array}$ & $\begin{array}{c}0.0606 \\
(0.0312) \\
*\end{array}$ & $\begin{array}{c}0.1502 \\
\underset{* \star \star}{(0.0460)}\end{array}$ & $\begin{array}{c}0.1761 \\
\underset{\star \star}{(0.0679)}\end{array}$ & $\begin{array}{c}0.0185 \\
(0.0061) \\
* \star \star\end{array}$ & $\begin{array}{c}0.0405 \\
\underset{* \star 0}{* \star 097})\end{array}$ & $\begin{array}{c}0.0580 \\
(0.0192) \\
\star \star \star \\
\end{array}$ & $\begin{array}{c}0.0495 \\
(0.2062)\end{array}$ & $\begin{array}{c}-0.0220 \\
(0.3341)\end{array}$ & $\begin{array}{c}0.1614 \\
(0.4762)\end{array}$ \\
\hline (2a) & Some debt & $\begin{array}{c}0.0016 \\
(0.0134)\end{array}$ & $\begin{array}{c}-0.0189 \\
(0.0216)\end{array}$ & $\begin{array}{c}-0.0276 \\
(0.0240)\end{array}$ & $\begin{array}{c}-0.0628 \\
\underset{\star \star}{(0.0299)}\end{array}$ & $\begin{array}{c}-0.1376 \\
\underset{* \star \star}{(0.0436)}\end{array}$ & $\begin{array}{c}-0.1556 \\
\underset{\star \star}{(0.0648)}\end{array}$ & $\begin{array}{c}0.0172 \\
(0.0111)\end{array}$ & $\begin{array}{c}0.0102 \\
(0.0171)\end{array}$ & $\begin{array}{c}0.0050 \\
(0.0218)\end{array}$ & $\begin{array}{c}0.0226 \\
(0.1982)\end{array}$ & $\begin{array}{c}0.1088 \\
(0.3264)\end{array}$ & $\begin{array}{l}-0.0811 \\
(0.4617)\end{array}$ \\
\hline \multirow[t]{3}{*}{ (3a) } & High debt & $\begin{array}{r}-0.0170 \\
(0.0142)\end{array}$ & $\begin{array}{c}-0.0609 \\
\underset{* *}{(0.0240)}\end{array}$ & $\begin{array}{c}-0.0871 \\
\underset{\star \star \star \star}{(0.0261)}\end{array}$ & $\begin{array}{c}-0.0591 \\
(0.0312) \\
*\end{array}$ & $\begin{array}{c}-0.1150 \\
\underset{* \star}{(0.0477)}\end{array}$ & $\begin{array}{c}-0.1214 \\
\underset{*}{(0.0717)}\end{array}$ & $\begin{array}{l}-0.0061 \\
(0.0141)\end{array}$ & $\begin{array}{c}-0.0477 \\
(0.0259) \\
*\end{array}$ & $\begin{array}{c}-0.0774 \\
\underset{\star \star \star 0231)}{(* 2}\end{array}$ & $\begin{array}{c}-0.1688 \\
(0.3210)\end{array}$ & $\begin{array}{c}-0.1587 \\
(0.4674)\end{array}$ & $\begin{array}{c}-0.4150 \\
(0.6594)\end{array}$ \\
\hline & $\mathrm{N}$ & 611,201 & 611,201 & 611,201 & 131,028 & 131,028 & 131,028 & 362,366 & 362,366 & 362,366 & 117,807 & 117,807 & 117,807 \\
\hline & \multicolumn{13}{|c|}{ Product market regulation with respect to entry barriers } \\
\hline (1b) & Base (no debt) & $\begin{array}{c}0.0218 \\
(0.0114) \\
*\end{array}$ & $\begin{array}{c}0.0475 \\
\underset{* \star}{(0.0197)}\end{array}$ & $\begin{array}{c}0.0669 \\
\underset{\star \star \star \star}{(0.0249)}\end{array}$ & $\begin{array}{c}0.0739 \\
\underset{\star \star}{(0.0341)}\end{array}$ & $\begin{array}{c}0.1526 \\
\underset{* \star \star}{(0.0437)}\end{array}$ & $\begin{array}{c}0.1798 \\
\underset{\star \star}{(0.0704)}\end{array}$ & $\begin{array}{c}0.0163 \\
\underset{\star \star}{(0.0070)}\end{array}$ & $\begin{array}{c}0.0389 \\
(0.0109) \\
* \star \star \\
\end{array}$ & $\begin{array}{c}0.0597 \\
\underset{\star \star}{(0.0212)}\end{array}$ & $\begin{array}{c}-0.0563 \\
(0.2799)\end{array}$ & $\begin{array}{c}-0.2658 \\
(0.5775)\end{array}$ & $\begin{array}{c}0.1461 \\
(0.7563)\end{array}$ \\
\hline (2b) & Some debt & $\begin{array}{c}0.0054 \\
(0.0129)\end{array}$ & $\begin{array}{l}-0.0106 \\
(0.0201)\end{array}$ & $\begin{array}{c}-0.0200 \\
(0.0237)\end{array}$ & $\begin{array}{c}-0.0708 \\
\underset{\star \star}{(0.0328)}\end{array}$ & $\begin{array}{c}-0.1359 \\
\underset{* * \star}{(0.0418)}\end{array}$ & $\begin{array}{c}-0.1540 \\
\underset{* \star}{(0.0681)}\end{array}$ & $\begin{array}{c}0.0188 \\
(0.0112)\end{array}$ & $\begin{array}{c}0.0121 \\
(0.0174)\end{array}$ & $\begin{array}{c}0.0060 \\
(0.0229)\end{array}$ & $\begin{array}{c}0.1240 \\
(0.2737)\end{array}$ & $\begin{array}{c}0.3396 \\
(0.5617)\end{array}$ & $\begin{array}{c}-0.0745 \\
(0.7287)\end{array}$ \\
\hline (3b) & High debt & $\begin{array}{c}-0.0130 \\
(0.0136)\end{array}$ & $\begin{array}{c}-0.0602 \\
\underset{* \star}{(0.0243)}\end{array}$ & $\begin{array}{c}-0.0920 \\
\underset{\star \star \star \star}{(0245)}\end{array}$ & $\begin{array}{c}-0.0627 \\
(0.0340) \\
*\end{array}$ & $\begin{array}{c}-0.1206 \\
\underset{* \star}{(0.0466)}\end{array}$ & $\begin{array}{c}-0.1318 \\
\underset{\star}{(0.0770)}\end{array}$ & $\begin{array}{l}-0.0030 \\
(0.0134)\end{array}$ & $\begin{array}{c}-0.0450 \\
(0.0255) \\
\star\end{array}$ & $\begin{array}{c}-0.0759 \\
(0.0232) \\
\star \star \star \\
\end{array}$ & $\begin{array}{c}0.0066 \\
(0.4015)\end{array}$ & $\begin{array}{c}0.2513 \\
(0.8019)\end{array}$ & $\begin{array}{c}-0.2998 \\
(1.0623)\end{array}$ \\
\hline & $\mathrm{N}$ & 614,050 & 614,050 & 614,050 & 130,925 & 130,925 & 130,925 & 361,168 & 361,168 & 361,168 & 121,957 & 121,957 & 121,957 \\
\hline
\end{tabular}

Note: Regressions include controls for reforms in the previous and subsequent two years as well as country-industry dummies, country-year dummies and industry-year dummies. Standard errors are robust and clustered by country and industry. ${ }^{*},{ }^{* *},{ }^{* * *}$ refer to statistical significance levels of $10 \%, 5 \%$ and $1 \%$ respectively.

\subsection{Disentangling the role of credit demand and credit supply}

In order to more formally isolate the role of credit supply from that of credit demand, we now make use of a triple differences approach, building on previous work by Rajan and Zingales (1998), that focuses on the differential effect of product market reforms among firms in industries that are heavily dependent on external finance versus firms that are not in periods where credit supply is constrained versus periods where credit is flush.

External dependence is measured by the difference between capital expenditure and cash flows over capital expenditure as in Rajan and Zingales (1998). This measure gives an indication of the degree of external finance that is needed to finance capital expenditures. In practice, the measurement of external dependence $(d)$ is based on the partial prediction of the following empirical model:

(2) $d_{i t}=\alpha_{a}+v_{c}+\eta_{j}+\theta_{t}+\varepsilon_{i t}$

which describes external dependence as a function of age dummies $\left(\alpha_{a}\right)$, country dummies $\left(v_{c}\right)$, industry dummies $\left(\eta_{j}\right)$ and time dummies $\left(\theta_{t}\right)$. $\varepsilon_{i t}$ represents a random error term. The model is estimated for firms in the United Kingdom and the United States. This reflects the assumption, in the spirit of Rajan and Zingales (1998), that financial frictions are negligible in those countries. External dependence is defined as the expected value of external dependence based on the industry dummies conditional on age, country and 
year fixed effects. The standardised level of external dependence by industry (with zero mean and unit standard deviation) reported in Table A6. ${ }^{44}$

Aggregate conditions are measured using the following regime switching function $F($.$) (Auerbach and$ Gorodnichenko, 2013):

(3) $F\left(z_{i t}\right)=\frac{\exp \left(-\gamma z_{i t}\right)}{1+\exp \left(-\gamma z_{i t}\right)}, \quad \gamma>0$

where $\mathrm{z}$ is an indicator of the aggregate credit conditions normalized to have zero mean and unit variance in each country. Aggregate credit conditions are measured by aggregate bank lending to the nonfinancial corporate sector as provided by the BIS. As in Auerbach and Gorodichencko (2013), we use $\gamma=1.5$ for the analysis of periods of weak and strong credit growth. One advantage of this formulation is that it provides a smooth transition between good and bad times, derived from the empirical distribution of country-specific growth rates, without having to rely on ad-hoc thresholds.

Using $F^{L}=F\left(z_{i t}\right)$ and $F^{H}=1-F\left(z_{i t}\right)$, we can extend the baseline model given in equation (1) to analyse how the impact of product market reforms on capital growth $(k)$ depends on the demand for external credit during periods of weak and rapid credit growth as follows:

$$
\begin{aligned}
& \text { (4) } \\
& k_{i t+S}-k_{i t-1}=\beta^{L} F^{L} R_{j c t}+\beta^{H} F^{H} R_{j c t}+\gamma^{L} \hat{d}_{j} F^{L}+\gamma^{H} \hat{d}_{j} F^{H}+\delta^{L} \hat{d}_{j} F^{L} R_{j c t}+\delta_{s}^{H} \hat{d}_{j} F^{H} R_{j c t}+ \\
& \varphi X_{i t-1}+\sum_{s=-2}^{S} \rho_{s} R_{j c t+s}+\eta_{c j}+\theta_{j t}+v_{c t}+\varepsilon_{i t} \\
& \forall s=0,1,2
\end{aligned}
$$

where $\beta^{L}$ and $\beta^{H}$ capture the role of respectively weak and strong aggregate credit growth for the impact of product market reforms on investment, $\gamma^{L}$ and $\gamma^{H}$ capture the differential effect of a one standarddeviation increase in external dependence for investment during respectively weak and strong aggregate credit conditions and $\delta^{L}$ and $\delta^{L}$ capture the differential effect of a one standard-deviation increase in external dependence on the impact of product market reforms on investment during, respectively, periods of weak and strong aggregate credit growth. ${ }^{45}$ Serving as the benchmark countries to assess external dependence, the United Kingdom and the United States are excluded from the regressions.

\subsection{Results}

As a first step, we check whether our identification is correct, i.e. we assess the role of external dependence and aggregate conditions for investment in the absence of product market reforms. This is captured by the simple interactions in the bottom two rows of Table 12. These interaction terms are statistically insignificant when considering all PMR industries and hence cast doubt of the usefulness of the present framework in the context of product market reforms. However, when restricting the sample to network industries the results are consistent with expectations. External dependence has a tendency to reduce investment when aggregate credit growth is weak, i.e. credit-constrained firms invest less in

44. It shows that external dependence tends to be higher in more capital-intensive industries, such as air and road transport, and lower in industries that are less capital-intensive such as professional services.

45. Note that since external dependence is time-invariant, it will be absorbed by the country-industry fixed effects. 
recessions when credit supply is limited. Moreover, the difference between the coefficients on external dependence in high and low credit growth regimes is statistically significant. This suggests focusing on network industries when considering the role of credit conditions for the impact of product market reforms on investment.

There is only weak evidence that external dependence and aggregate credit conditions also affect the impact of product market reforms on investment. This is captured by the triple interactions in rows 3 and 4 of Table 12. These coefficients suggest that firms that are heavily dependent on external finance invest considerably more following a pro-competitive product market reform when aggregate credit conditions are strong than firms that do not rely on external finance. This is the case both when using all PMR industries and when focusing just on network industries. Moreover, when aggregate credit conditions are weak, firms that are heavily reliant on external finance respond similarly to product market deregulation than firms that are not. These results provide some limited evidence that credit constraints matter, but also that this is more important in good times than in bad times.

Table 12. The role of aggregate credit conditions and external financial dependence for the impact of product market reforms on investment

selected coefficients

\begin{tabular}{|c|c|c|c|c|c|c|}
\hline & \multicolumn{3}{|c|}{ Network industries } & \multicolumn{3}{|c|}{ All PMR industries } \\
\hline & $t=0$ & $t=1$ & $t=2$ & $t=0$ & $t=1$ & $t=2$ \\
\hline Major reform * high credit growth * external dependence & $\begin{array}{c}0.1362 \\
(0.0748) \\
*\end{array}$ & $\begin{array}{c}0.2770 \\
\underset{\star \star}{(0.1356)}\end{array}$ & $\begin{array}{c}0.3703 \\
\underset{\star \star \star}{0.1702)}\end{array}$ & $\begin{array}{c}0.2236 \\
\underset{* \star \star}{(0.0844)}\end{array}$ & $\begin{array}{c}0.2008 \\
\underset{* *}{(0.0919)}\end{array}$ & $\begin{array}{c}0.2165 \\
(0.1214) \\
*\end{array}$ \\
\hline Major reform * low credit growth * external dependence & $\begin{array}{c}0.0628 \\
(0.1207)\end{array}$ & $\begin{array}{c}0.0117 \\
(0.1854)\end{array}$ & $\begin{array}{c}-0.0057 \\
(0.2176)\end{array}$ & $\begin{array}{l}-0.0559 \\
(0.1253)\end{array}$ & $\begin{array}{l}-0.0343 \\
(0.1190)\end{array}$ & $\begin{array}{c}0.0245 \\
(0.1766)\end{array}$ \\
\hline High credit growth * external dependence & $\begin{array}{c}0.0049 \\
(0.0284)\end{array}$ & $\begin{array}{l}-0.0485 \\
(0.0478)\end{array}$ & $\begin{array}{l}-0.0900 \\
(0.0576)\end{array}$ & $\begin{array}{l}-0.0144 \\
(0.0245)\end{array}$ & $\begin{array}{l}-0.0278 \\
(0.0283)\end{array}$ & $\begin{array}{l}-0.0203 \\
(0.0376)\end{array}$ \\
\hline Low credit growth * external dependence & $\begin{array}{c}-0.0631 \\
(0.0324) \\
\star\end{array}$ & $\begin{array}{c}-0.1224 \\
(0.0525) \\
\star \star\end{array}$ & $\begin{array}{c}-0.1793 \\
\underset{\star \star}{0.0638})\end{array}$ & $\begin{array}{l}-0.0048 \\
(0.0331)\end{array}$ & $\begin{array}{l}-0.0091 \\
(0.0326)\end{array}$ & $\begin{array}{l}-0.0124 \\
(0.0416)\end{array}$ \\
\hline Major reform * high credit growth & $\begin{array}{c}-0.0842 \\
(0.0353) \\
\star \star\end{array}$ & $\begin{array}{c}-0.1227 \\
(0.0649) \\
*\end{array}$ & $\begin{array}{c}-0.1685 \\
(0.0928) \\
*\end{array}$ & $\begin{array}{c}-0.0726 \\
(0.0389) \\
\star\end{array}$ & $\begin{array}{l}-0.0595 \\
(0.0455)\end{array}$ & $\begin{array}{l}-0.0332 \\
(0.0604)\end{array}$ \\
\hline Major reform * low credit growth & $\begin{array}{c}0.0103 \\
(0.0578)\end{array}$ & $\begin{array}{c}0.0399 \\
(0.0747)\end{array}$ & $\begin{array}{c}0.0576 \\
(0.0914)\end{array}$ & $\begin{array}{c}0.0640 \\
(0.0482)\end{array}$ & $\begin{array}{c}0.0477 \\
(0.0468)\end{array}$ & $\begin{array}{l}-0.0005 \\
(0.0752)\end{array}$ \\
\hline
\end{tabular}

Note: Regressions include controls for reforms in the previous and subsequent two years as well as country-industry dummies, country-year dummies and industry-year dummies. Standard errors are robust and clustered by country and industry. ${ }^{*},{ }^{* *},{ }^{* * *}$ refer to statistical significance levels of $10 \%, 5 \%$ and $1 \%$ respectively. 


\section{The indirect effects of product market reforms through input-output linkages}

The effects of product market reforms may not just be limited to the industries in which they take place (direct effects), but also extend to other industries through input-output linkages, and even to other countries, through trade linkages (indirect effects). Product market reforms in upstream industries can have important effects on firms downstream for several reasons. First, it may increase input quality and variety, which each can lead to an increase in productivity in downstream firms. Second, it may lower prices and hence boost competitiveness. Third, it may increase profitability and thereby incentives to innovate. Taking account of the indirect effects of PMRs is clearly very important for understanding the macroeconomic effect of reforms.

Few previous studies have considered the indirect effects of product market reforms. The main exceptions are Barrone and Cingano (2011), Bourles et al. (2013) and OECD (2016) who analyse the longterm effects of reforms in regulated services industries on downstream industries using cross-country industry-level data. They focus on sectoral differences in the use of intermediate inputs in downstream manufacturing industries supplied by industries upstream using input-output tables. ${ }^{46}$ Arnold and others (2011, 2015) use firm-level data for respectively Czech Republic and India to analyse the impact of deregulation in the services sector on manufacturing firms downstream, while Lanau and Topalova (2016) conduct a similar analysis for Italy. The impact of deregulation is identified using input-output linkages at the sectoral level in a similar way as the studies discussed above.

We make a number of contributions to the literature. First, we make use of a potentially better identification strategy than has been used so far by combining firm-level information on intermediate input use with sectoral information on input-output linkages. This not only significantly increases the identifying variation, but allows controlling for country-sector-specific business conditions by means of countryindustry-year fixed effects. ${ }^{47}$ Second, we do not only consider input-output linkages between firms in the same country but also across countries. This allows assessing to what extent there are international spillovers from product market reforms through the supply channel described above. Third, in line with the analysis of the direct effects of product market reforms, we concentrate on the dynamic effects over the short to medium term. As any potential effects on total factor productivity may materialise relatively slowly hence we focus on employment, value-added and output as possible outcome variables.

\subsection{Methodology}

The indirect effects of product market reforms, within and between countries, on the $\log$ difference in the outcome variable of interest between $t-1$ and $t+s$ in firm $i$ can be modeled as follows:

(5) $Y_{i t+s}-Y_{i t-1}=\alpha+\beta_{1} \sum_{k} \omega_{j k c} R_{k c t}+\beta_{2} \sum_{k d} \omega_{j k c d} R_{k d t}+\gamma X_{i t-1}+\eta_{c j}+\theta_{j t}+v_{c t}+\varepsilon_{i t}$ $\forall s=0,1,2$

where $R_{k c t}$ refers to product market reforms in upstream industry $\mathrm{k}$, country c and year $\mathrm{t}, \omega_{j k \mathrm{c}}$ to the share of intermediate inputs supplied by upstream industry $\mathrm{k}$ to industry $\mathrm{j}$ using input-output tables for 1995 . The total exposure of industry $\mathrm{j}$ to product market reforms in upstream industries is thus given by the sum of

46. Arnold et al (2011) and Gal (2013) apply the same philosophy at the firm-level, investigating whether productivity growth is affected by liberalization in a neo-Schumpeterian, distance-to-the-frontier framework.

47. Bourles et al. (2013) do not control for either country*industry or industry*year fixed effects. 
input-output weighted product market reforms across all supplying industries, $\sum_{k} \omega_{j k c} R_{k c t}(k \neq j)$. In the case of international spillovers, the focus is on the sum of input-output weighted product market markets reforms abroad across supplying industries and countries $\sum_{k d} \omega_{j k c d} R_{k d t}(k \neq j$ and $d \neq c)$. As before, the model further controls for a wide variety of observable and unobservable factors, including firm size, firm age, debt leverage, total factor productivity, country-industry fixed effects $\left(\eta_{c j}\right)$, country-year dummies $\left(v_{c t}\right)$ and industry-year dummies $\left(\theta_{j t}\right) . \varepsilon_{i t}$ represents a random error term.

In principle, equation (5) allows identifying the impact of product market reforms on the average downstream firm. However, concerns have been expressed about the ability of measuring spillovers effects adequately using input-output linkages at the industry level, particularly given the substantial degree of heterogeneity in intermediate input use across firms within industries (Gorodnichenko et al, 2015). Another concern is that product market reforms in upstream industries may to some extent be driven by economic conditions in their main using industries and hence be endogenous.

To address these concerns, the present analysis makes use of firm-level information to identify the indirect effects of product market reforms. This is done by combining firm-level information on total intermediate-input use with industry-level information on the use of intermediate inputs by industry $\mathrm{j}$ from industry k. The empirical model above is therefore extended as follows:

(6)

$$
\begin{aligned}
& Y_{i t+s}-Y_{i t-1}= \\
& \alpha+\beta_{1} \sum_{k} \omega_{j k c} R_{k c t}+\beta_{2} \sum_{k d} \omega_{j k c d} R_{k d t}+\gamma_{1} M_{i t-1} \sum_{k} \omega_{j k c} R_{k c t}+\gamma_{2} M_{i t-1} \sum_{k d} \omega_{j k c d} R_{k d t}+\delta_{1} M_{i t-1}+ \\
& \delta_{2} X_{i t-1}+\eta_{c j}+\theta_{j t}+v_{c t}+\varepsilon_{i t} \\
& \forall s=0,1,2
\end{aligned}
$$

where an interaction term consisting of the input-output weighted measure of exposure of industry $\mathrm{j}$ to product market reforms in upstream industries and the share of intermediate input use in total sales for each firms lagged by one period $\left(M_{i t-1}\right)$ is now added to the model. In order to control for the independent effect of intermediate input use at the firm level, this is also included independently. Intermediate input use is included in deviation from the country*industry*year mean. Consequently, the $\beta^{\prime} s$ capture the average effect of product market reforms in upstream industries on downstream firms and the $\gamma^{\prime} s$ the differential effect of a one percentage-point increase in total intermediate input use relative to the cell average (coefficients are multiplied times 100 for readability).

By focusing on differences in total intermediate input use within country-industry-year groups the model largely takes account of endogeneity concerns related to the potential impact of economic conditions in downstream industries on reforms in upstream industries. However, it is possible to even better by controlling for sector-specific business conditions through the inclusion of country-industry-year fixed effects as follows:

(7) $Y_{i t+s}-Y_{i t-1}=\alpha+\gamma_{1} M_{i t-1} \sum_{k} \omega_{j k c} R_{k c t}+\gamma_{2} M_{i t-1} \sum_{k d} \omega_{j k d} R_{k d t}+\delta_{1} M_{i t-1}+\delta_{2} X_{i t-1}+\eta_{c j t}+\varepsilon_{i t}$ $\forall s=0,1,2$

where represents $\eta_{c j t}$ a country, industry and year fixed effect and hence effectively controls for sectorspecific conditions. 


\subsection{Data and descriptive statistics}

Sectoral measures of exposure to product market reforms in upstream industries in the same country, $\sum_{k} \omega_{j k c} R_{k c t}$, or abroad, $\sum_{k d} \omega_{j k d} R_{k d t}$, are obtained by combining our indicators on product market reforms with information from World Input-Output Database (WIOD). ${ }^{48}$ When constructing the input-output weights we exclude linkages within a single industry (the diagonal elements of the inputoutput matrix) in order to mitigate endogeneity concerns. Moreover, weights are fixed at the beginning of the sample (1995) to avoid any potential endogeneity concerns. ${ }^{49}$

Since the data in the WIOD are slightly more aggregated than our indicators of product market regulations, the latter are collapsed to match the industry classification in the WIOD. We thus focus on the indirect effects of major product market reforms in the following seven industries: i) electricity and gas; ii) post and telecoms; iii) airlines; iv) rail and road transport; v) retail; vi) business services (accounting and legal services); and vii) technical services (architecture and engineering services).

The output of these "PMR sectors" makes up, on average across countries, nearly $40 \%$ of all inputs that other sectors use (Table A7, Annex A3). Among them, the importance of retail and in particular professional services has increased over time (from 20 to 25\% from 1995 to 2011), further underlying the value of including them in our analysis.

Direct information on the use of intermediate inputs at the firm-level in Orbis is not available for all countries. This means that we can only analyse the indirect effects of product market reforms across about 15 OECD countries. The analysis focuses on the period 1998-2013. Finally, note that since deflators are only available at the country-industry level and no firm-level prices are observed - which is a standard limitation for most firm-level datasets -, any variation in measured output across firms within a given country-industry cell can reflect both price and quantity effects. This should be taken into account when interpreting the results that rely on differential effects by input-intensities.

\subsection{Results}

The results based on specification (7) are reported summarised in Table 13. For ease of presentation, only the coefficients on the interaction term of interest are reported. These give the differential effect of product market reforms depending on the intensity of intermediate inputs in output (times 100).

The results indicate that product market reforms in upstream industries in the same country have more positive effects on output, productivity and employment in downstream firms, the greater their exposure to such reforms, i.e. the higher the share of intermediate inputs in production. There is also some indication that product market reforms in upstream industries have positive spillovers in downstream firms in other countries, but the evidence is considerably weaker in this case and only limited to employment. One may therefore tentatively conclude that if there are international spillovers, these are likely to be positive but rather small. Given the limited importance of international spillovers the remaining discussion will focus on spillovers within countries.

48. See Timmer et al. (2015) for details.

49. In contrast to Bourles et al. (2013), we use the direct instead of the ultimate links between the original producer and the ultimate user. Focusing on the direct links is more appropriate in the present context, since we concentrate on the short term effects of reforms. The indicators using ultimate vs. direct links are very strongly correlated (around 0.9). 
As in the case of the direct effects of product market reforms, the indirect effects strengthen over time. A ten percentage point increase in intermediate input intensity increases the impact of product market reforms in upstream industries on downstream firms by about $2 \%$ in terms of value added, and no significant impact on output. While these results generally suggest that domestic spillovers are economically important, the results do not allow assessing their overall impact. This is because the estimated effect is the differential effect depending on the intensity of intermediate inputs and not the average effect. However, as argued in OECD (2016b), they can be used to back out an average effect under the assumption that product market reforms have no indirect effect on downstream effects on firms that have zero material input intensity. This seems reasonable in the present context since such firms are not exposed to product market reforms upstream.

Table 13. The effects of product market reforms in upstream industries on downstream firms

Selected coefficients based on equation 7

\begin{tabular}{|c|c|c|c|c|c|c|c|c|c|}
\hline & \multicolumn{3}{|c|}{ log employment (L) } & \multicolumn{3}{|c|}{ log value added (VA) } & \multicolumn{3}{|c|}{$\log$ sales $(\mathrm{Y})$} \\
\hline & $t=0$ & $\mathrm{t}=1$ & $t=2$ & $t=0$ & $t=1$ & $t=2$ & $t=0$ & $t=1$ & $t=2$ \\
\hline \multicolumn{10}{|l|}{ All industries } \\
\hline Backward direct domestic * Input use & $\begin{array}{c}0.0027 \\
(0.0014) \\
\star\end{array}$ & $\begin{array}{c}0.0060 \\
(0.0024) \\
\star \star\end{array}$ & $\begin{array}{c}0.0074 \\
(0.0034) \\
\star \star\end{array}$ & $\begin{array}{c}0.1007 \\
\underset{*}{(0.0247)}\end{array}$ & $\begin{array}{c}0.1381 \\
\underset{* \star 0 * \star}{(0.0350)}\end{array}$ & $\begin{array}{c}0.1944 \\
\underset{*}{(0.0499)} \\
* \star \star\end{array}$ & $\begin{array}{c}0.0009 \\
(0.0073)\end{array}$ & $\begin{array}{c}0.0052 \\
(0.0070)\end{array}$ & $\begin{array}{c}0.0056 \\
(0.0075)\end{array}$ \\
\hline Backward direct international * Input use & $\begin{array}{c}0.0024 \\
(0.0012) \\
\star \star\end{array}$ & $\begin{array}{c}0.0051 \\
(0.0020) \\
\star \star \star \star\end{array}$ & $\begin{array}{c}0.0061 \\
(0.0028) \\
\star \star\end{array}$ & $\begin{array}{c}0.0029 \\
(0.0078)\end{array}$ & $\begin{array}{c}0.0062 \\
(0.0090)\end{array}$ & $\begin{array}{c}0.0118 \\
(0.0103)\end{array}$ & $\begin{array}{c}0.0009 \\
(0.0059)\end{array}$ & $\begin{array}{c}0.0015 \\
(0.0059)\end{array}$ & $\begin{array}{c}0.0006 \\
(0.0063)\end{array}$ \\
\hline Observations & $2,980,298$ & $2,980,298$ & $2,980,298$ & $2,312,319$ & $2,312,319$ & $2,312,319$ & $2,980,298$ & $2,980,298$ & $2,980,298$ \\
\hline \multicolumn{10}{|l|}{ Manufacturing } \\
\hline Backward direct domestic * Input use & $\begin{array}{c}0.0393 \\
(0.0110) \\
\star \star \star\end{array}$ & $\begin{array}{c}0.0886 \\
(0.0147) \\
\star \star \star\end{array}$ & $\begin{array}{c}0.1174 \\
(0.0197) \\
\star \star \star\end{array}$ & $\begin{array}{c}0.1853 \\
(0.0174) \\
\star \star \star\end{array}$ & $\begin{array}{c}0.2576 \\
\underset{* \star * \star}{(0.0254)}\end{array}$ & $\begin{array}{c}0.3574 \\
(0.0384) \\
\star \star \star\end{array}$ & $\begin{array}{c}0.0614 \\
(0.0169) \\
\star \star \star\end{array}$ & $\begin{array}{c}0.0522 \\
(0.0215) \\
\star \star\end{array}$ & $\begin{array}{c}0.0731 \\
(0.0274) \\
\star \star \star\end{array}$ \\
\hline Backward direct international * Input use & $\begin{array}{l}-0.0020 \\
(0.0015)\end{array}$ & $\begin{array}{l}-0.0029 \\
(0.0026)\end{array}$ & $\begin{array}{l}-0.0058 \\
(0.0046)\end{array}$ & $\begin{array}{c}0.0164 \\
(0.0091) \\
\star\end{array}$ & $\begin{array}{c}0.0166 \\
(0.0118)\end{array}$ & $\begin{array}{c}0.0176 \\
(0.0142)\end{array}$ & $\begin{array}{l}-0.0023 \\
(0.0049)\end{array}$ & $\begin{array}{l}-0.0017 \\
(0.0044)\end{array}$ & $\begin{array}{c}0.0010 \\
(0.0035)\end{array}$ \\
\hline Observations & 746,217 & 746,217 & 746,217 & 602,902 & 602,902 & 602,902 & 746,217 & 746,217 & 746,217 \\
\hline \multicolumn{10}{|l|}{ Services } \\
\hline Backward direct domestic * Input use & $\begin{array}{c}0.0026 \\
(0.0015) \\
*\end{array}$ & $\begin{array}{c}0.0054 \\
(0.0025) \\
\star \star\end{array}$ & $\begin{array}{c}0.0071 \\
(0.0037) \\
*\end{array}$ & $\begin{array}{c}0.0797 \\
(0.0252) \\
\star \star \star \star\end{array}$ & $\begin{array}{c}0.1093 \\
\left(\begin{array}{c}0.0358) \\
\star * \star\end{array}\right.\end{array}$ & $\begin{array}{c}0.1565 \\
(0.0527) \\
\star \star \star\end{array}$ & $\begin{array}{l}-0.0004 \\
(0.0091)\end{array}$ & $\begin{array}{c}0.0044 \\
(0.0089)\end{array}$ & $\begin{array}{c}0.0031 \\
(0.0095)\end{array}$ \\
\hline Backward direct international * Input use & $\begin{array}{c}0.0024 \\
(0.0014) \\
\star\end{array}$ & $\begin{array}{c}0.0047 \\
\underset{* \star}{(0.0022)}\end{array}$ & $\begin{array}{c}0.0060 \\
(0.0032) \\
*\end{array}$ & $\begin{array}{l}-0.0045 \\
(0.0081)\end{array}$ & $\begin{array}{l}-0.0006 \\
(0.0097)\end{array}$ & $\begin{array}{c}0.0074 \\
(0.0116)\end{array}$ & $\begin{array}{c}0.0000 \\
(0.0077)\end{array}$ & $\begin{array}{c}0.0010 \\
(0.0077)\end{array}$ & $\begin{array}{l}-0.0016 \\
(0.0082)\end{array}$ \\
\hline Observations & $2,234,081$ & $2,234,081$ & $2,234,081$ & $1,709,417$ & $1,709,417$ & $1,709,417$ & $2,234,081$ & $2,234,081$ & $2,234,081$ \\
\hline
\end{tabular}

Note: Regressions include firm-level controls (including intermediate input intensity), country-industry-year fixed effects. Standard errors are robust and clustered by country and industry. ${ }^{*},{ }^{* *},{ }^{* * *}$ refer to statistical significance levels of $10 \%, 5 \%$ and $1 \%$ respectively.

The nature and importance of domestic spillovers differs between downstream firms in manufacturing and services. Competition is typically considered to be more intense in manufacturing, since it tends to be less regulated and more exposed to competition from abroad. ${ }^{50}$ Comparing the impact of

50. The exposure of manufacturing firms to reforms in upstream industries is also likely to be higher than that of services firms. While this should not affect the estimated coefficients since they are conditional on the 
product market reforms in upstream industries on manufacturing and services firms, separately, it appears that the impact of upstream product market reforms is more positive for employment, value added and output for manufacturing firms than for services firms.

One possible interpretation of these results is that competition is stronger among manufacturing firms, resulting in larger output-price (and hence also employment-price) elasticities. Assuming that product market reforms upstream allow for price reductions due to cheaper inputs and output demand is relatively elastic, a reduction in prices will lead to an increase in the value of output. The increase is even larger for value added since in this case the output price reduction effect is mitigated by the declining price of intermediates. By contrast, competition is typically less strong among services, resulting in less elastic output demand. This may be expected to dampen the impact of output price declines, on output, value added and employment. The lower price elasticity of output demand may also explain the absence of an effect on output.

\section{Concluding remarks}

This paper analyses the effects of de jure product market reforms in the short and medium term across 10 regulated industries and 18 advanced economies for the period 1998-2013 using internationally comparable firm-level data based on Orbis.

The effects of product market reforms on the typical firm are found to be positive and increasing over time. After two years, major reform increases capital by $4 \%$, output by $3 \%$ and employment by $1.5 \%$. Moreover, the analysis shows there are systematic differences in the impact of reforms across incumbent firms depending on their industry, size and financial health. There is also evidence that product market reforms promote firm entry. Apart from its impact on firms in deregulated sectors, product market reforms have a positive impact on the performance of firms downstream that make intensive use of the products or services from the liberalised sectors.

These findings provide important insights into the role of product market reforms in the present context. They suggest that for the typical firms their effects materialise quite quickly, and possibly, more quickly than for the economy as a whole. They also point at complementarities between product market reforms and policy measures that seek to strengthen corporate balance sheets and ease credit constraints on firms; both the level of debt and the availability of credit are shown to affect the effectiveness of product market reforms in boosting investment.

This paper also helps to understand why it can be difficult to implement product market reforms despite their long-term gains. In particular, it shows that in network industries relatively large incumbent firms tend to restructure employment and downscale investment plans in an effort to maintain market share in the face of increased competition. This may partly explain why large firms lobby against such reforms and workers who are at risk of losing their jobs are also reluctant to support them. This points to the usefulness of complementary policies that mitigate the cost of job loss and help workers to move into new jobs in other firms, such as targeted active labour market policies (OECD, 2016b).

degree of exposure, this nevertheless implies that the consequences of product market reforms in upstream industries are more pronounced in manufacturing from an economic perspective. 


\section{ANNEX A1. CONSTRUCTING ANNUAL INDICATORS ON THE RESTRICTIVENESS OF PRODUCT MARKET REGULATIONS FOR RETAIL AND PROFESSIONAL SERVICES}

Annual indicators on the restrictiveness of product market regulation for retail and professional services are constructed by combining the OECD indicators for retail and professional services for fiveyear intervals with information from a new database developed by the IMF on structural reforms (Duval et al., 2016) and, to a very limited extent, a manual search in Google in the event no information on product market reforms was found in the IMF database even though such reforms did occur according to the OECD indicators. This annex describes in detail how the annual series were constructed in practice.

\section{Identifying the timing of reforms}

The IMF's structural reform database provides a inventory of structural reforms based on information from the OECD Economic Surveys with detailed information on their nature and timing. Using this database to identify the timing of reforms is not straightforward because it provides an overwhelming amount of information and the information has not been harmonised. In order to allow identifying the timing of product market reforms in an efficient and objective manner a search algorithm was set up to allow identifying reforms in each sector and with respect to each major component of product market regulation. The component of product market regulation in each sector is identified by focusing on a number of keywords derived from the OECD questionnaire for each policy domain as well as the name of the sector. A reform is identified if we obtain a hit for both the sector and one of the keywords associated with the policy domain. Since the nature of rules and regulations with respect to the different categories of professional services tends to be relatively similar the four professional services were regrouped into two categories: i) business services, consisting of respectively accounting and legal services, and ii) technical services, consisting of respectively engineering and architecture services. An overview of the sectors, policy domains and keywords is given in Table A1 below. The year of the reform refers to the announcement date, or if this is not available, the date in which it entered into force and in a limited number of cases the year before it was reported in the OECD Economic Survey was used.

Table A1. Keywords for string search in each sector and policy domain

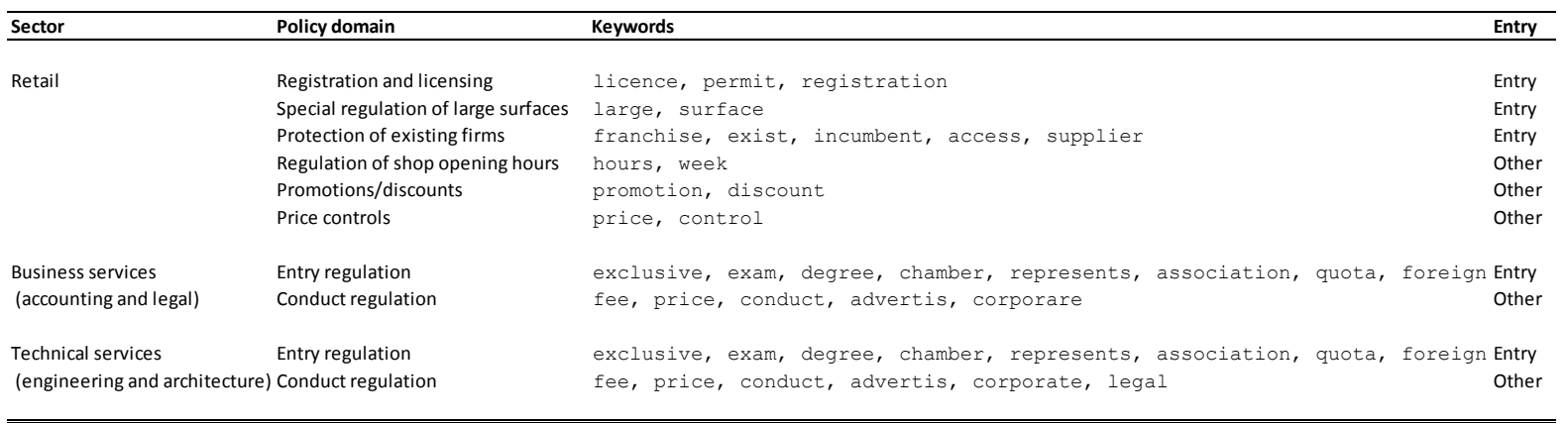

In the event that the IMF database did not yield any reforms but the OECD indicators suggest a reform has taken place a manual search was conducted. This resulted in the identification of only minor number of new reforms. 
Filling up the OECD indicators for the intermediate years

The OECD indicators on the restrictiveness of product market regulations for retail and professional services for five yearly intervals are filled up using the information on the timing of product market reforms discussed above. This was done in four steps. Table A2 summarises the role of each step for each sector.

For any policy domains and sectors where there was no change in the OECD indicator over the five-year window, the indicator was held constant throughout the period. This allowed filling up 168 observations.

For policy domains and sectors where the OECD indicator had changed and one or several reforms were identified based on the IMF database the intermediate years were filled up. If there was only one reform within the five-year interval the indicator was held constant at its latest value until the year of the reform and changed to its next value from the year of the reform onwards. If there were several reforms within the five-year window it was assumed that the quantitative impact of each reform on the PMR indicator was the same. This allowed filling up 296 observations.

For policy domains and sectors where the OECD indicator had changed, no reforms were identified in the IMF database, the results from the manual search in Google were used. The procedure for interpolation was the same as when using the IMF database. This step is not very important and resulted in eight filled observations.

For policy domains and sectors where the OECD indicator had changed, but no information on the timing of the reform was found in either the IMF database or through the manual search in Google, the reforms in other policy domains within the same sector were used. This involved making the assumption that reforms were synchronised within sectors. This allowed filling up 92 observations.

At the end of this procedure, $16 \%$ of missing cases remained empty. The large majority of these relate to professional services. The final database contains a flag indicating whether the information comes directly from the OECD or has imputed with one of the steps above.

Table A2. Constructing annual indicators for retail and professional services

\begin{tabular}{l|c|cccc|cc|cc}
\hline \multicolumn{1}{c|}{ Sector } & $\begin{array}{c}\text { OECD indicators } \\
\text { (a) }\end{array}$ & $\begin{array}{c}\text { No change } \\
\text { (1) Kept constant }\end{array}$ & $\begin{array}{c}\text { Change } \\
\text { (2) IMF database }\end{array}$ & $\begin{array}{c}\text { Change } \\
\text { (3) Manual search }\end{array}$ & $\begin{array}{c}\text { Change } \\
\text { (4) Other policy } \\
\text { domain in sector }\end{array}$ & $\begin{array}{c}\text { Filled } \\
\text { (b) }\end{array}$ & $\begin{array}{c}\text { Missing } \\
\text { (c) }\end{array}$ & $\begin{array}{c}\text { Total } \\
\text { (a+b+c) }\end{array}$ \\
\hline Retail & 85 & 44 & 100 & 8 & 68 & 220 & 28 \\
Business services & 83 & 36 & 160 & 0 & 16 & 212 & 28 \\
Technical services & 82 & 88 & 36 & 0 & 8 & 132 & 323 \\
Total & 250 & 168 & 296 & 8 & 92 & 564 & 104 \\
\hline
\end{tabular}

The econometric analysis focuses mainly on major product market reforms with respect to the overall restrictiveness of product market regulation as well as that with respect to entry barriers only. A major pro-competitive reform is defined as a reduction in the indicator of product market regulation while an anti-competitive reform is defined as an increase in the regulatory stance of at least the same size.

We consider three different types of major reforms. The first type is defined as a change in the PMR indicator of at least 0.5 . This corresponds to almost the 5\% largest changes in the PMR indicator regulation across all 10 sectors (R1). While this rule ensures that only major reforms are taken into account it also implies that the number of reforms can vary widely across sectors. In order to ensure that the 
number of reforms is similar across sectors the second reform type is defined in terms of the top five percentile in each sector. However, since the number of major reforms in professional services is relatively limited this means that also relatively small changes in the PMR indicator are classified as major reform changes. To address this issue, we use the highest of either the ninety-fifth percentile or a 0.5 change in the indicator of product market regulation (R2). The fourth type makes use of indicators of major product market reforms developed by Duval et al. (2016) for network industries in combination with R1 for retail and professional services (R3). The former are based on a narrative approach that makes use of qualitative information about the significance of the reform as well as changes in the OECD indicator.

Table A3 shows the number of major reforms, in either direction, with respect to the overall restrictiveness of product market regulation and entry barriers for each sector during the period 1998-2013.

Table A3. The number of major reforms

by measure and sector, 1998-2013

\begin{tabular}{lcccccc}
\hline & \multicolumn{3}{c}{ Overall restrictiveness } & \multicolumn{3}{c}{ Barriers to entry } \\
& R1 & R2 & R3 & R1 & R2 & R3 \\
& Absolute & Mixed & Narrative & Absolute & Mixed & Narrative \\
\hline \multirow{2}{*}{ Electricity } & 48 & 37 & 26 & 43 & 40 & 24 \\
Gas & 42 & 31 & 29 & 51 & 43 & 25 \\
Telecom & 49 & 32 & 26 & 48 & 38 & 23 \\
Post & 33 & 19 & 25 & 43 & 42 & 19 \\
Rail & 28 & 21 & 19 & 24 & 363 & 14 \\
Airlines & 37 & 34 & 10 & 23 & 361 & 10 \\
Road & 18 & 18 & 12 & 14 & 353 & 12 \\
Retail & 16 & 16 & 16 & 16 & 16 & 16 \\
Business services & 6 & 6 & 6 & 5 & 5 & 5 \\
Technical services & 1 & 1 & 1 & 1 & 1 & 1 \\
& & & & & & \\
Total & 278 & 215 & 170 & 268 & 1262 & 149 \\
& & & & & & \\
\hline
\end{tabular}




\section{ANNEX A2. THE FIRM-LEVEL DATABASE BASED ON ORBIS ${ }^{51}$}

The following steps are necessary to prepare data as supplied by the Bureau van Dijk for econometric work: (i) defining the dimensions of the dataset in terms of countries, industries and years; i) selecting valid company accounts; (iii) ensuring comparability of monetary variables across countries and over time (PPP conversion and deflation); (iv) constructing a key economic variables from balance sheet information; and v) filtering out extreme observations and small cells.

\section{Defining the dimensions of the dataset}

Given that the present focus on product market reforms, we restrict the starting sample to those countries and years for which OECD indicators on the restrictiveness of product market regulations are available over time. Historical indicators that allow going back to 1998 are mainly available for OECD countries. Moreover, to be considered for the analysis, countries should also have a number of observations with non-missing information on employment and revenues in Orbis.

The time period considered is 1998-2013. Since there is an approximately 2-year reporting lag, 2013 is the latest year that is observed for most firms in the 2015 vintage of Orbis. It also corresponds to the latest year for the PMR indicators are available. In order to ensure good coverage in Orbis going back to 1998 we also make use of two earlier vintages of the dataset. This is necessary since the standard timespan of Orbis is a maximum of 5-10 years depending on the country and considerably shorter for the majority of firms. This limits the scope of the analysis and the ability to follow firms through extended periods of time. The historical dataset is thus constructed by combining three different vintages of Orbis, each five years apart, for respectively 2005, 2010 and 2015. To implement the merge across vintages, correspondence tables provided by Bureau van Dijk between the old and new company identifiers (BvD ID-s) are used. This results in good and relatively stable coverage for the period 1998 to 2013.

The sectoral coverage of the dataset is restricted to the market economy. More specifically, we concentrate on the non-farm, non-financial business sector. This corresponds to industry codes 5-82 in NACE Rev. 2 (or ISIC Rev. 4) in the 2015 vintage or 10-74 in NACE Rev. 1.1 (or ISIC Rev. 3) in earlier vintages. A one-to-one industry correspondence between NACE Rev.1 and NACE Rev.2 is derived by using information on firms for which both industry codes are available (the 2010 vintage has information in both the old and the new classification system) and focusing only the most frequent combinations of the old and the new classification system at the 4 digit level. ${ }^{52}$

\section{Keeping valid company accounts}

Only those company accounts are kept that satisfy the following criteria:

51. This builds on previous work by Gal (2013), Kalemli-Ozcan et al (2015) and Ribeiro et al (2010). We are grateful to Tom Baskind, Lauren Canino and Matt Gauthier from Bureau van Dijk for their generous help with the construction of the historical dataset and to Sebnem Kalemli-Ozcan and Sevcan Yesiltas for helpful discussions about the use of Orbis.

52. The official conversion table between the two systems does not yield a unique correspondence but instead an n-to-m mapping. This means that some "old" (i.e. ISIC 3) industries are split into several new ones (i.e. ISIC 4), and some new industries are the result of a merge across several old ones. 
- They refer to a whole calendar year (12 months and no less) to make sure that the economic content is comparable.

- Since Orbis comprises of multi-firm groups as well as standalone firms, the accounts can either refer to consolidated values across subsidiaries or unconsolidated accounts of the headquarters only. Moreover, in many countries, a large fraction of accounts cannot be identified either as consolidated or unconsolidated, indicated by a code "LF" (limited financials) by BvD, which essentially means incomplete accounts. To avoid double-counting, we retain company accounts that are either (i) unconsolidated (U1 and U2 codes in Orbis) or (ii) those that are consolidated but not with an unconsolidated counterpart (C1) or (ii) those whose consolidation status is unknown (LF). While the retention of different accounting types is not ideal from the perspective of comparability, this approach is used to not unduly restrict country coverage at the outset, as certain countries have mostly consolidated while others mostly unconsolidated accounts.

- To arrive at a unique Bureau van Dijk identifier for each company account, duplicate accounts are removed. This is done by privileging company accounts based on Local Registry Filing ${ }^{53}$, by far the most common filing type in the dataset, and if still duplicates are present, selecting those with a wider set of non-missing values for key balance sheet items. ${ }^{54}$

\section{Ensuring comparability of monetary variables across countries and over time}

To allow for monetary items to be compared across countries and over time, variables are expressed in purchasing power parity (PPP) adjusted US dollars for 2005. As the original data is stored in USD at market exchange rates, they first need to be converted back to the local currency. Nominal values are converted into real ones by to applying local currency deflators obtained from OECD STAN (ISIC4 version). Four types of deflators are considered: gross output, value added, intermediate inputs and gross fixed capital formation. The deflated values are subsequently converted to 2005 US dollars using industry level PPPs obtained from Timmer and Inklaar (2014). For further details on how PPP data is combined with the deflators, see Gal (2013).

Due to missing values in the OECD STAN - in particular, not all countries have all the 2-digit level information in all the years -, deflation is not straightforward in practice. The following procedure was adopted to circumvent this problem. First, industry-level deflators are used for country*industry*year combinations when available. Second, if missing, it is filled up by applying the growth rate in the price index at the next level of aggregation. ${ }^{55}$ This process is continued until reaching the 1-letter detail of the industry classification (i.e. manufacturing, construction, etc.). If that level is still missing, then instead of using the country level average, the cross-country median in that particular industry group (and year) is used. The motivation for doing so is that output price developments can differ in manufacturing and services, and since most of the economies in our sample tend to be open, it is considered a reasonable approximation to use the tendencies in other countries. Since the latest version of OECD STAN goes up to

53. Company account may either be based on annual reports or local registry filing. The latter is preferred as this is the filing type of about $98 \%$ of company accounts.

54. The list of variables we base our choice on is the following: Total_assets Tangible_fixed_assets Long_term_debt Loans Number_of_employees Revenue Export_revenue Material_costs Costs_of_employees Depreciation_and_amortization Cash_flow Added_value EBITDA

55. For instance, if textiles (industry code D13 in STAN) has missing information on the value added deflator for a particular country in a particular year, the growth rate from the immediate higher level (Textiles and wearing apparel, industry code D13T14) is used. If that is missing as well, then once more the immediate higher level (Textiles, wearing apparel, leather and related products [CB], industry code D13T15) is used. 
2012, 2013 values are deflated using national accounts data at 1-digit detail. For cases where the gross output deflators or intermediate input deflators were missing, value added deflators are used instead. Finally, all deflators are rebased to $2005=1$.

\section{Deriving economic variables from balance sheet items}

Economic variables on capital stock and multi-factor productivity are derived from the balance sheet items contained in the dataset. To obtain a measure of real capital stock $K_{i t}$, the perpetual inventory method (PIM) is applied to the book value of tangible fixed assets $K_{i t}^{B V}$ (for each firm $i$ and year $t$ ), (see Gilhooly, 2009, for a firm-level application). PIM describes the dynamic evolution of the capital stock, as driven by the degree of depreciation $\delta_{\text {it }}$, investments $I_{i t}$ and the value of the capital stock in the previous period $K_{i, t-1}$ :

$$
K_{i t}=K_{i, t-1}\left(1-\delta_{\text {it }}\right)+I_{i t}
$$

The real value of gross investment $I_{i t}$ is defined as the annual change in book value of fixed tangible assets $K_{i t}^{B V}$ plus depreciation $D e p r_{i t}^{B V}$, deflated by the gross fixed capital formation deflator $P I_{\mathrm{c} j t}$ (specific to each country $c$ and 2-digit industry $j$ ):

$$
I_{i t}=\left(K_{i t}^{B V}-K_{i, t-1}^{B V}+D_{e p r}^{B V}\right) / P I_{c j t} .
$$

The depreciation rate is defined as the observed book value of depreciation divided by the sum of the previous value of capital stock and depreciation. The starting value of the real capital stock $K_{i 0}$ for each firm is the book value of fixed tangible assets deflated by the investment deflator:

$$
K_{i 0}=K_{i 0}^{B V} / P I_{c j 0}
$$

Missing values in the raw data for fixed tangible assets are filled up by linear interpolation, invoking the implicit assumption that depreciation offsets gross investments ("steady state"). The same principle is applied for missing values for depreciation. Following Gopinath et al (2013), for Spain, the fixed asset variable is used instead of fixed tangible assets, in order to avoid spurious level shifts around 2009 due to a reclassification of certain assets across the tangible-intangible groups.

To estimate multi-factor productivity (MFP), we estimate regressions of the following form, for each 2-digit industry $j$ :

$$
y_{i t}=\alpha_{j} k_{i t}+\beta_{j} l_{i t}+v_{c, j}+\eta_{t, j}+\varepsilon_{i t}
$$

where $y_{i t}$ denotes log of real value added, $k_{i t}$ denotes the log of real capital stock, and $l_{i t}$ the $\log$ of the number of employees. $v_{c, j}$ and $\eta_{t, j}$ are country and year fixed effects, respectively. $\varepsilon_{i t}$ is the residual, our measure of multi-factor productivity. Since Ordinary least squares (OLS) estimates tend to be upward biased due to the positive correlation between the unobserved productivity shock and the factor inputs that results from the fact that firms react to productivity shocks by adjusting their inputs, we use the control function approach proposed by Wooldridge (2009) by taking account of movements in intermediate inputs - arguably the most easily adjustable factor input. ${ }^{56}$

56. However, we also constructed simpler productivity estimates based on the index-number method essentially, a Solow residual using observed labour shares at the industry level from OECD STAN - or simple OLS estimates of the production function. 
Before running the production function estimations, a number of additional cleaning rules were applied. In particular, within each 2-digit industry, those observations are excluded where $\log$ (value added/employment), $\log ($ capital/employment) and $\log$ (materials/employment) are outside the top or bottom $0.5 \%$ of their distribution.

\section{Filtering out extreme observations and small cells}

In addition to the preparatory steps described above which may be deemed useful for any analysis based on Orbis, we apply in addition a number cleaning rules which are more directly relevant for the present analysis:

Micro firms and self-employed units are removed by keeping only company accounts with at least 3 employees.

Since our methodology focuses on growth rates of real revenues, value added or capital stocks, implausibly high changes are filtered out. In particular, they are set to missing when their growth rates are related to large level shifts (larger than 100-fold increase or smaller than 1/100-fold decrease). In addition, the same variables are also set to missing if they are related to more than 50-fold changes that are reversed the next year ("spikes").

Only firms with at least four consecutive observations with valid information are retained. This is the minimum number of observations to analyse the short-term impact of reforms on firm outcomes between $\mathrm{t}-1$ and $\mathrm{t}+2$.

Only country-industry*year cells are kept with at least 50 observations and country cells with at least 1000 observations. This ensures that the variation in the firm-level data that corresponds to the variation in the policy indicators is not driven by excessively small cells.

\section{Descriptive statistics}

Table A4 provides an indication of the size of the sample (i) before filtering out extreme observations and small cells and (ii) after the filtering is applied. It shows that the starting sample contains about 30 million firm-year observations. This sample represents the RES-Orbis dataset as prepared by the Research Department (RES) of the IMF. After filtering, the number of observations is reduced to about 5.5 million. 
Table A4. Sample statistics by country, sector and year

\begin{tabular}{|c|c|c|c|c|c|}
\hline \multicolumn{3}{|c|}{ Number of firms } & \multicolumn{3}{|c|}{ Number of firms } \\
\hline Country & $\begin{array}{l}\text { Original } \\
\text { sample }\end{array}$ & Final sample & Year & $\begin{array}{l}\text { Original } \\
\text { sample }\end{array}$ & Final sample \\
\hline AUT & 156,957 & 21,366 & 1998 & 847,660 & 75,130 \\
\hline BEL & 492,317 & 78,582 & 1999 & $1,110,714$ & 108,922 \\
\hline CZK & $1,213,434$ & 415,136 & 2000 & $1,310,739$ & 151,084 \\
\hline DEU & $3,175,757$ & 716,342 & 2001 & $1,494,056$ & 253,616 \\
\hline DNK & 135,280 & 12,128 & 2002 & $1,658,101$ & 358,875 \\
\hline EST & 411,947 & 66,599 & 2003 & $1,688,689$ & 373,908 \\
\hline ESP & $6,209,845$ & $1,142,084$ & 2004 & $1,733,261$ & 330,871 \\
\hline FIN & 561,875 & 82,598 & 2005 & $1,716,832$ & 239,105 \\
\hline FRA & $4,478,464$ & 772,300 & 2006 & $2,081,919$ & 253,210 \\
\hline GBR & 952,665 & 99,279 & 2007 & $2,175,571$ & 309,784 \\
\hline GRC & 308,917 & 133,734 & 2008 & $2,307,992$ & 383,069 \\
\hline ITA & $3,281,145$ & 316,443 & 2009 & $2,395,372$ & 480,585 \\
\hline JPN & $2,681,981$ & 678,158 & 2010 & $2,420,320$ & 495,372 \\
\hline KOR & 813,750 & 99,585 & 2011 & $2,637,251$ & 550,370 \\
\hline PRT & $1,824,987$ & 254,711 & 2012 & $2,354,311$ & 569,273 \\
\hline SWE & $2,628,580$ & 553,177 & 2013 & $2,049,326$ & 607,521 \\
\hline SVN & 224,115 & 17,675 & & & \\
\hline SVK & 430,098 & 80,798 & & & \\
\hline Total & $29,982,114$ & $5,540,695$ & Total & $29,982,114$ & $5,540,695$ \\
\hline
\end{tabular}

In order to get an indication of the coverage of the database with respect to the population of all businesses, we compare the sample with the universe of companies using official statistical sources from the Structural Demographics and Business Statistics of the OECD (SDBS) for the number of employees. This is done for the starting sample before filtering the data (the RES-Orbis dataset).

The Structural Demographics and Business Statistics of the OECD (SDBS) contains information on the number of enterprises, establishments, employees by country * industry * employment size class cells, for each year. ${ }^{57}$ The underlying sources of the information are national administrative databases which cover the universe of firms - typically business registers. As such, the SDBS can be used to assess the degree of coverage in Orbis by comparing the number of firms in the data with the population of companies. In principle, it can also be used to construct weights to correct for the potential underrepresentation of certain types of firms.

To match the SDBS with information from Orbis by industry and firm size classes we proceeded as follows. First, using Business Statistics by Size Class, we focus on three firm size classes for 2010. The three firm size classes are less than 10 employees, between 10 and 20 employees and more than 20 employees. Second, missing information for 2010 is filled up using linear interpolation within each country*industry*size-class cell. Third, whenever a detailed industry level has missing information on the size distribution in a particular country and year, it is interpolated by using the one-level-higher industry detail level.

57. Information on output-type variables (value added or gross output) in SDBS is more limited and also hampered by comparability issues related to the definition of gross output in the retail sector. 
Table A5 shows that coverage in terms of employment is close to complete among large firms and in network industries (80-100\%), while other sectors, populated by smaller firms, tend to have lower coverage (20-40\%). The fact that larger firms are better captured is a well-documented feature of Orbis (Gal, 2013; Kalemli-Ozcan et al, 2015). To some extent, this is also a general feature of firm level datasets, as reporting standards are stricter above certain size thresholds. This pattern in turn translates to generally better coverage for network industries, which tend to have larger businesses. ${ }^{58}$ Even within firm size classes, however, it seems that network firms are more likely to be included in the sample than firms from the two other broad sectors.

Table A5. Employment coverage in Orbis by PMR sectors and size classes 2010

\begin{tabular}{|c|c|c|c|c|c|}
\hline \multirow[t]{2}{*}{ PMR sectors } & & \multicolumn{3}{|c|}{$\begin{array}{l}\text { Firm size class } \\
\text { (based on employment) }\end{array}$} & \multirow[t]{2}{*}{ Total } \\
\hline & & $<10$ & $10-20$ & $>=20$ & \\
\hline \multirow{7}{*}{$\begin{array}{l}\text { Network } \\
\text { industries }\end{array}$} & Electricity & $26.8 \%$ & $73.3 \%$ & $99.2 \%$ & $95.6 \%$ \\
\hline & Gas & $32.9 \%$ & $94.3 \%$ & $85.2 \%$ & $83.9 \%$ \\
\hline & Telecom & $14.8 \%$ & $39.8 \%$ & $96.4 \%$ & $91.0 \%$ \\
\hline & Post & $4.1 \%$ & $13.2 \%$ & $73.7 \%$ & $69.7 \%$ \\
\hline & Rail & $86.8 \%$ & $36.9 \%$ & $103.3 \%$ & $103.1 \%$ \\
\hline & Airlines & $15.8 \%$ & $37.3 \%$ & $78.1 \%$ & $76.9 \%$ \\
\hline & Road & $15.4 \%$ & $44.1 \%$ & $24.4 \%$ & $23.9 \%$ \\
\hline Retail & & $8.6 \%$ & $22.6 \%$ & $51.4 \%$ & $34.6 \%$ \\
\hline \multirow{2}{*}{$\begin{array}{l}\text { Professional } \\
\text { services }\end{array}$} & Accounting \& Legal & $7.9 \%$ & $13.1 \%$ & $42.2 \%$ & $21.0 \%$ \\
\hline & Architecture \& Engineering & $7.2 \%$ & $31.3 \%$ & $63.3 \%$ & $33.0 \%$ \\
\hline \multicolumn{2}{|c|}{ All PMR sectors } & $9.0 \%$ & $24.7 \%$ & $55.7 \%$ & $39.0 \%$ \\
\hline
\end{tabular}

Note: This table does not include Japan and Korea due to lack of appropriate breakdowns of the data in SDBS.

58. The larger than $100 \%$ coverage for large railway firms can be driven by the small number of businesses there in combination with potential differences in the very detailed level (4-digit) industry classifications in Orbis and in SDBS. 


\section{ANNEX A3. OTHER DATA SOURCES}

External financial dependence

External dependence is measured by the difference between capital expenditure and cash flows over capital expenditure as in Rajan and Zingales (1998). In practice, the measurement of external dependence $(d)$ is based on the partial prediction of the following empirical model:

(A5) $d_{i t}=\alpha_{a}+v_{c}+\eta_{j}+\theta_{t}+\varepsilon_{i t}$ which describes external dependence as a function of age dummies $\left(\alpha_{a}\right)$, country dummies $\left(v_{c}\right)$, industry dummies $\left(\eta_{j}\right)$ and time dummies $\left(\theta_{t}\right)$. $\varepsilon_{i t}$ represents a random error term. The model is estimated for firms in the United Kingdom and the United States. External dependence is defined as the expected value of external dependence based on the industry fixed effects conditional on age, country and year fixed effects.

Table A6 documents the standardized level of external dependence by industry (with zero mean and unit standard deviation). It shows that external dependence tends to be higher in more capital-intensive industries, such as air and road transport, and lower in industries that are less capital-intensive such as professional services.

Table A6. External financial dependence

(Capital expenditures - cash flows) / capital expenditures

\begin{tabular}{lc}
\hline & $\begin{array}{c}\text { External financial dependence } \\
\text { Normalised values }\end{array}$ \\
\hline & \\
Electricity & 0.515 \\
Gas & 0.251 \\
Telecommunications & 0.448 \\
Postal services & 0.293 \\
Rail transport & -0.084 \\
Air transport & 0.749 \\
Road transport & 0.702 \\
Retail trade & 0.340 \\
Business services & -2.617 \\
Technical services & -0.598 \\
\end{tabular}

Note: Averages across firms for the United States and the United Kingdom, standardised to have zero mean and unit standard deviation. 


\section{Input-output linkages}

To assess the importance of the sectors for which indicators on the stance of product market regulations are available (the PMR sectors) in the production process of other parts of the economy, we make use of input-output tables (WIOD, Timmer et al, 2015). They record the flow of goods and services from the industries that sell them - as outputs - to the purchasing industries - as intermediate inputs - for each industry-pair, country and year. Consequently, they allow calculating the intensity of the use of the outputs (denoted by $G O$, for gross output) of PMR sectors as inputs for each country (c), purchasing industry $(j)$, supplying industry $(k)$ and year $(t)$ as follows:

(A6) $w_{c j k t}=\frac{G O_{c j k t}}{\Sigma_{l} G O_{c j l t}}$

Table A7 summarises these intensities for each of the supplying PMR sectors, averaged across all countries and purchasing industries $\left(\bar{w}_{c k t}\right)$. Several interesting patterns emerge. First, the role of the PMR sectors in providing inputs for the other sectors is substantial, and considerably larger than their share in employment. Second, their share has increased from about 35\% in 1995 to about 39\% in 2011. Third, the increasing important of the PMR sectors as intermediate inputs suppliers is almost entirely driven by the professional services sector, while it has been broadly constant for network industries and retail trade.

Table A7. The importance of PMR sectors as suppliers of intermediate inputs to other sectors

\begin{tabular}{lccc} 
& 1995 & 2011 & $\begin{array}{c}\text { Difference } \\
\text { between 2011 } \\
\text { and 1995 }\end{array}$ \\
\hline Electricity \& Gas & $5.5 \%$ & $5.6 \%$ & $0.0 \%$ \\
Rail \& Road & $5.3 \%$ & $5.2 \%$ & $-0.1 \%$ \\
Airlines & $0.7 \%$ & $0.3 \%$ & $-0.4 \%$ \\
Telecom \& Post & $2.9 \%$ & $2.7 \%$ & $-0.3 \%$ \\
\hline All network & $\mathbf{1 4 . 5 \%}$ & $\mathbf{1 3 . 8 \%}$ & $-\mathbf{0 . 7 \%}$ \\
\hline & & & \\
Retail & $7.0 \%$ & $7.7 \%$ & $0.7 \%$ \\
Professional senvices & $13.1 \%$ & $17.2 \%$ & $4.2 \%$ \\
\hline & & & \\
All PMR sectors & $\mathbf{3 4 . 6 \%}$ & $\mathbf{3 8 . 7 \%}$ & $\mathbf{4 . 2 \%}$ \\
\hline
\end{tabular}

Source: Authors' calculations using WIOD (Timmer et al, 2015) 
ECO/WKP(2016)35

\section{ANNEX A4. FURTHER RESULTS}

Table A8. First-stage of instrumental variable regressions selected coefficients

\begin{tabular}{|c|c|c|c|}
\hline & & \multicolumn{2}{|c|}{ Major reform } \\
\hline & & Overall restrictiveness & Entry barriers \\
\hline (1) & IV - absolute reform pressure & $\begin{array}{c}0.2074 \\
(0.0162) \\
\star \star \star\end{array}$ & $\begin{array}{c}0.1464 \\
(0.0169) \\
\star \star \star\end{array}$ \\
\hline$(2)$ & IV - relative reform pressure between countries & $\begin{array}{c}0.1843 \\
(0.0147) \\
\star \star \star\end{array}$ & $\begin{array}{c}0.1302 \\
(0.0149) \\
\star \star \star\end{array}$ \\
\hline
\end{tabular}


ECO/WKP(2016)35

Table A9. The short-term effects of product market reforms by industry and firm size

$\%$ change in the outcome variable of interest in years after a major reduction in entry barriers,

\begin{tabular}{|c|c|c|c|c|c|c|c|c|c|c|}
\hline & & \multicolumn{2}{|c|}{ Network industries } & \multicolumn{3}{|c|}{ Retail } & \multicolumn{4}{|c|}{ Professional senvices } \\
\hline & & $t=0$ & $t=1$ & $t=2$ & $t=0$ & $t=1$ & $t=2$ & $t=0$ & $t=1$ & $t=2$ \\
\hline \multicolumn{11}{|c|}{ Panel A. log employment (L) } \\
\hline (1a) & Base (small firms) & $\begin{array}{c}0.0184 \\
(0.0113)\end{array}$ & $\begin{array}{c}0.0284 \\
\underset{\star \star}{0.0131)}\end{array}$ & $\begin{array}{c}0.0496 \\
(0.0164) \\
\star \star \star\end{array}$ & $\begin{array}{l}-0.0042 \\
(0.0046)\end{array}$ & $\begin{array}{c}0.0017 \\
(0.0087)\end{array}$ & $\begin{array}{c}0.0080 \\
(0.0116)\end{array}$ & $\begin{array}{l}-0.0111 \\
(0.0167)\end{array}$ & $\begin{array}{c}0.0192 \\
(0.0187)\end{array}$ & $\begin{array}{c}0.0555 \\
(0.0232) \\
\star \star\end{array}$ \\
\hline (2a) & Medium-sized firms & $\begin{array}{c}-0.0433 \\
(0.0218) \\
*\end{array}$ & $\begin{array}{c}-0.0503 \\
(0.0178) \\
\star \star \star\end{array}$ & $\begin{array}{c}-0.0682 \\
(0.0161) \\
\star \star \star\end{array}$ & $\begin{array}{c}0.0173 \\
(0.0103)\end{array}$ & $\begin{array}{c}0.0242 \\
(0.0140)\end{array}$ & $\begin{array}{c}0.0304 \\
(0.0181)\end{array}$ & $\begin{array}{c}0.0206 \\
(0.1262)\end{array}$ & $\begin{array}{l}-0.1725 \\
(0.1428)\end{array}$ & $\begin{array}{c}-0.3476 \\
(0.1680) \\
\star \star\end{array}$ \\
\hline \multirow[t]{3}{*}{ (3a) } & Large firms & $\begin{array}{c}-0.0364 \\
(0.0109) \\
\star \star \star \star\end{array}$ & $\begin{array}{c}-0.0439 \\
(0.0093) \\
\star \star \star\end{array}$ & $\begin{array}{c}-0.0676 \\
(0.0188) \\
\star \star \star\end{array}$ & $\begin{array}{c}0.0267 \\
(0.0089) \\
\star \star \star\end{array}$ & $\begin{array}{c}0.0374 \\
(0.0137) \\
\star \star\end{array}$ & $\begin{array}{c}0.0491 \\
(0.0186) \\
\star \star\end{array}$ & $\begin{array}{c}0.0992 \\
(0.0820)\end{array}$ & $\begin{array}{c}0.0882 \\
(0.0759)\end{array}$ & $\begin{array}{c}0.1252 \\
(0.1614)\end{array}$ \\
\hline & $\mathrm{N}$ & 163,797 & 163,797 & 163,797 & 515,852 & 515,852 & 515,852 & 138,874 & 138,874 & 138,874 \\
\hline & Panel B. log capita & & & & & & & & & \\
\hline$(1 b)$ & Base (small firms) & $\begin{array}{c}0.0233 \\
\underset{* * \star}{0.0078)}\end{array}$ & $\begin{array}{c}0.0581 \\
(0.0140) \\
\star \star \star \star\end{array}$ & $\begin{array}{c}0.0948 \\
(0.0200) \\
\star \star \star \star\end{array}$ & $\begin{array}{c}0.0243 \\
(0.0108) \\
\star \star *\end{array}$ & $\begin{array}{c}0.0321 \\
(0.0155) \\
*\end{array}$ & $\begin{array}{c}0.0387 \\
(0.0158) \\
\star \star\end{array}$ & $\begin{array}{l}-0.0154 \\
(0.0240)\end{array}$ & $\begin{array}{l}-0.0010 \\
(0.0504)\end{array}$ & $\begin{array}{l}-0.0046 \\
(0.0769)\end{array}$ \\
\hline$(2 b)$ & Medium-sized firms & $\begin{array}{l}-0.0108 \\
(0.0189)\end{array}$ & $\begin{array}{c}-0.0117 \\
(0.0262)\end{array}$ & $\begin{array}{c}-0.0379 \\
(0.0312)\end{array}$ & $\begin{array}{c}0.0208 \\
(0.0047) \\
\star \star \star\end{array}$ & $\begin{array}{c}0.0204 \\
(0.0062) \\
\star \star \star\end{array}$ & $\begin{array}{c}0.0334 \\
(0.0091) \\
\star \star \star \star\end{array}$ & $\begin{array}{c}0.3396 \\
(0.1661) \\
\star \star\end{array}$ & $\begin{array}{c}0.0565 \\
(0.3791)\end{array}$ & $\begin{array}{c}-0.0024 \\
(0.5485)\end{array}$ \\
\hline \multirow[t]{3}{*}{$(3 b)$} & Large firms & $\begin{array}{c}-0.0099 \\
(0.0154)\end{array}$ & $\begin{array}{c}-0.0590 \\
(0.0278) \\
\star \star *\end{array}$ & $\begin{array}{c}-0.0954 \\
(0.0402) \\
\star \star\end{array}$ & $\begin{array}{c}0.0220 \\
(0.0067) \\
\star \star \star\end{array}$ & $\begin{array}{c}0.0244 \\
(0.0147)\end{array}$ & $\begin{array}{c}0.0388 \\
(0.0238)\end{array}$ & $\begin{array}{c}0.0846 \\
(0.1453)\end{array}$ & $\begin{array}{c}0.1407 \\
(0.2600)\end{array}$ & $\begin{array}{c}0.2538 \\
(0.4114)\end{array}$ \\
\hline & $\mathrm{N}$ & 130,828 & 130,828 & 130,828 & 388,596 & 388,596 & 388,596 & 112,226 & 112,226 & 112,226 \\
\hline & Panel C. log sales & & & & & & & & & \\
\hline$(1 c)$ & Base (small firms) & $\begin{array}{c}0.0286 \\
(0.0108) \\
\star \star \star\end{array}$ & $\begin{array}{c}0.0436 \\
(0.0153) \\
\star \star \star\end{array}$ & $\begin{array}{c}0.0342 \\
(0.0143) \\
* *\end{array}$ & $\begin{array}{c}0.0098 \\
(0.0056) \\
*\end{array}$ & $\begin{array}{c}0.0287 \\
(0.0130) \\
* *\end{array}$ & $\begin{array}{c}0.0482 \\
(0.0302)\end{array}$ & $\begin{array}{l}-0.0205 \\
(0.0341)\end{array}$ & $\begin{array}{c}0.0541 \\
(0.0431)\end{array}$ & $\begin{array}{c}0.1215 \\
(0.0528) \\
* *\end{array}$ \\
\hline$(2 c)$ & Medium-sized firms & $\begin{array}{c}-0.0237 \\
(0.0093) \\
\star \star\end{array}$ & $\begin{array}{c}-0.0275 \\
(0.0129) \\
\star \star\end{array}$ & $\begin{array}{l}-0.0166 \\
(0.0153)\end{array}$ & $\begin{array}{c}0.0038 \\
(0.0055)\end{array}$ & $\begin{array}{c}0.0044 \\
(0.0065)\end{array}$ & $\begin{array}{c}0.0028 \\
(0.0061)\end{array}$ & $\begin{array}{c}0.1067 \\
(0.2453)\end{array}$ & $\begin{array}{l}-0.2777 \\
(0.3467)\end{array}$ & $\begin{array}{l}-0.5389 \\
(0.3885)\end{array}$ \\
\hline \multirow[t]{2}{*}{ (3c) } & Large firms & $\begin{array}{l}-0.0058 \\
(0.0101)\end{array}$ & $\begin{array}{l}-0.0128 \\
(0.0121)\end{array}$ & $\begin{array}{l}-0.0084 \\
(0.0134)\end{array}$ & $\begin{array}{c}0.0064 \\
(0.0089)\end{array}$ & $\begin{array}{l}-0.0002 \\
(0.0162)\end{array}$ & $\begin{array}{l}-0.0015 \\
(0.0233)\end{array}$ & $\begin{array}{c}0.1655 \\
(0.1762)\end{array}$ & $\begin{array}{c}0.2275 \\
(0.2684)\end{array}$ & $\begin{array}{c}0.4204 \\
(0.4002)\end{array}$ \\
\hline & $\mathrm{N}$ & 163,797 & 163,797 & 163,797 & 515,852 & 515,852 & 515,852 & 138,874 & 138,874 & 138,874 \\
\hline
\end{tabular}

Note: Regressions control for reforms in the previous and subsequent two years, include firm-level controls, as well as countryindustry dummies, country-year dummies and industry-year dummies. Standard errors are robust and clustered by country and industry. ${ }^{*},{ }^{* *},{ }^{* *}$ refer to statistical significance levels of $10 \%, 5 \%$ and $1 \%$ respectively. Small, medium and large firms are defined as having 3-9 10-19 and 20+ employees, respectively, in year t-1. 
Table A10. The short-term effects of product market reforms by industry and firm age

$\%$ change in the outcome variable of interest in years after a major reduction in the overall restrictiveness of product market regulation, selected coefficients

\begin{tabular}{|c|c|c|c|c|c|c|c|c|c|c|}
\hline & & \multicolumn{2}{|c|}{ Network industries } & \multicolumn{3}{|c|}{ Retail } & \multicolumn{4}{|c|}{ Professional services } \\
\hline & & $t=0$ & $t=1$ & $t=2$ & $t=0$ & $t=1$ & $t=2$ & $t=0$ & $t=1$ & $t=2$ \\
\hline \multicolumn{11}{|c|}{ Panel A. log employment (L) } \\
\hline (1a) & Base (young firms) & $\begin{array}{c}0.0061 \\
(0.0078)\end{array}$ & $\begin{array}{c}0.0179 \\
(0.0135)\end{array}$ & $\begin{array}{c}0.0405 \\
(0.0176) \\
\star \star \star\end{array}$ & $\begin{array}{c}0.0008 \\
(0.0040)\end{array}$ & $\begin{array}{c}0.0056 \\
(0.0084)\end{array}$ & $\begin{array}{c}0.0070 \\
(0.0113)\end{array}$ & $\begin{array}{c}0.0067 \\
(0.0284)\end{array}$ & $\begin{array}{c}0.0532 \\
(0.0511)\end{array}$ & $\begin{array}{c}0.0538 \\
(0.0706)\end{array}$ \\
\hline (2a) & Medium-aged firms & $\begin{array}{l}-0.0113 \\
(0.0102)\end{array}$ & $\begin{array}{l}-0.0205 \\
(0.0124)\end{array}$ & $\begin{array}{c}-0.0410 \\
(0.0231) \\
*\end{array}$ & $\begin{array}{c}0.0017 \\
(0.0030)\end{array}$ & $\begin{array}{c}0.0036 \\
(0.0047)\end{array}$ & $\begin{array}{c}0.0069 \\
(0.0068)\end{array}$ & $\begin{array}{l}-0.0142 \\
(0.0367)\end{array}$ & $\begin{array}{c}-0.1266 \\
(0.1033)\end{array}$ & $\begin{array}{l}-0.1166 \\
(0.1288)\end{array}$ \\
\hline \multirow[t]{3}{*}{ (3a) } & Old firms & $\begin{array}{c}0.0001 \\
(0.0056)\end{array}$ & $\begin{array}{c}-0.0099 \\
(0.0125)\end{array}$ & $\begin{array}{l}-0.0201 \\
(0.0173)\end{array}$ & $\begin{array}{l}-0.0001 \\
(0.0025)\end{array}$ & $\begin{array}{l}-0.0028 \\
(0.0037)\end{array}$ & $\begin{array}{l}-0.0028 \\
(0.0047)\end{array}$ & $\begin{array}{l}-0.0141 \\
(0.0582)\end{array}$ & $\begin{array}{c}-0.0063 \\
(0.0604)\end{array}$ & $\begin{array}{c}0.0350 \\
(0.0912)\end{array}$ \\
\hline & $\mathrm{N}$ & 163,909 & 163,909 & 163,909 & 491,423 & 491,423 & 491,423 & 120,013 & 120,013 & 120,013 \\
\hline & Panel B. log capit & & & & & & & & & \\
\hline$(1 b)$ & Base (young firms) & $\begin{array}{c}0.0356 \\
(0.0094) \\
* * *\end{array}$ & $\begin{array}{c}0.0811 \\
\left(\begin{array}{c}0.0139) \\
* * *\end{array}\right.\end{array}$ & $\begin{array}{c}0.1138 \\
(0.0153) \\
* \star *\end{array}$ & $\begin{array}{c}0.0297 \\
(0.0074) \\
* \star *\end{array}$ & $\begin{array}{c}0.0343 \\
(0.0126) \\
* *\end{array}$ & $\begin{array}{c}0.0477 \\
(0.0191) \\
\star \star *\end{array}$ & $\begin{array}{l}-0.0150 \\
(0.0566)\end{array}$ & $\begin{array}{c}0.0565 \\
(0.0936)\end{array}$ & $\begin{array}{c}0.0449 \\
(0.1397)\end{array}$ \\
\hline$(2 \mathrm{~b})$ & Medium-aged firms & $\begin{array}{c}-0.0362 \\
(0.0139) \\
* *\end{array}$ & $\begin{array}{c}-0.0591 \\
(0.0216) \\
\star \star \star\end{array}$ & $\begin{array}{c}-0.0860 \\
(0.0250) \\
* \star \star\end{array}$ & $\begin{array}{c}0.0127 \\
(0.0060) \\
\star \star *\end{array}$ & $\begin{array}{c}0.0291 \\
(0.0095) \\
* \star \star\end{array}$ & $\begin{array}{c}0.0290 \\
(0.0167) \\
*\end{array}$ & $\begin{array}{c}0.1258 \\
(0.0954)\end{array}$ & $\begin{array}{c}0.0094 \\
(0.1502)\end{array}$ & $\begin{array}{c}-0.0121 \\
(0.1991)\end{array}$ \\
\hline \multirow[t]{3}{*}{ (3b) } & Old firms & $\begin{array}{c}-0.0458 \\
(0.0183) \\
\star \star\end{array}$ & $\begin{array}{c}-0.0936 \\
(0.0343) \\
\star \star \star\end{array}$ & $\begin{array}{c}-0.0994 \\
(0.0392) \\
\star \star\end{array}$ & $\begin{array}{c}0.0088 \\
(0.0071)\end{array}$ & $\begin{array}{c}0.0148 \\
(0.0103)\end{array}$ & $\begin{array}{c}0.0073 \\
(0.0153)\end{array}$ & $\begin{array}{c}-0.0043 \\
(0.1489)\end{array}$ & $\begin{array}{l}-0.1531 \\
(0.2824)\end{array}$ & $\begin{array}{c}-0.0283 \\
(0.2950)\end{array}$ \\
\hline & $\mathrm{N}$ & 130,939 & 130,939 & 130,939 & 386,237 & 386,237 & 386,237 & 94,338 & 94,338 & 94,338 \\
\hline & Panel C. log sales & & & & & & & & & \\
\hline (1c) & Base (young firms) & $\begin{array}{c}0.0278 \\
(0.0097) \\
\star \star *\end{array}$ & $\begin{array}{c}0.0466 \\
(0.0149) \\
\star \star \star\end{array}$ & $\begin{array}{c}0.0491 \\
(0.0180) \\
\star \star *\end{array}$ & $\begin{array}{c}0.0172 \\
(0.0126)\end{array}$ & $\begin{array}{c}0.0256 \\
(0.0209)\end{array}$ & $\begin{array}{c}0.0258 \\
(0.0292)\end{array}$ & $\begin{array}{c}0.0187 \\
(0.0549)\end{array}$ & $\begin{array}{c}0.0619 \\
(0.0871)\end{array}$ & $\begin{array}{c}0.1342 \\
(0.1248)\end{array}$ \\
\hline (2c) & Medium-aged firms & $\begin{array}{c}-0.0183 \\
(0.0098) \\
*\end{array}$ & $\begin{array}{c}-0.0303 \\
(0.0144) \\
\star \star\end{array}$ & $\begin{array}{c}-0.0399 \\
(0.0181) \\
\star \star\end{array}$ & $\begin{array}{l}-0.0093 \\
(0.0174)\end{array}$ & $\begin{array}{l}-0.0096 \\
(0.0157)\end{array}$ & $\begin{array}{l}-0.0091 \\
(0.0198)\end{array}$ & $\begin{array}{l}-0.0299 \\
(0.0916)\end{array}$ & $\begin{array}{l}-0.0442 \\
(0.1398)\end{array}$ & $\begin{array}{l}-0.1147 \\
(0.2045)\end{array}$ \\
\hline (3c) & Old firms & $\begin{array}{l}-0.0144 \\
(0.0107)\end{array}$ & $\begin{array}{c}-0.0368 \\
(0.0194) \\
*\end{array}$ & $\begin{array}{l}-0.0419 \\
(0.0279)\end{array}$ & $\begin{array}{l}-0.0127 \\
(0.0128)\end{array}$ & $\begin{array}{l}-0.0221 \\
(0.0143)\end{array}$ & $\begin{array}{l}-0.0199 \\
(0.0174)\end{array}$ & $\begin{array}{l}-0.0334 \\
(0.0888)\end{array}$ & $\begin{array}{c}-0.0783 \\
(0.1643)\end{array}$ & $\begin{array}{l}-0.1231 \\
(0.2126)\end{array}$ \\
\hline & $\mathrm{N}$ & 163,909 & 163,909 & 163,909 & 491,423 & 491,423 & 491,423 & 120,013 & 120,013 & 120,013 \\
\hline
\end{tabular}

Note: Regressions control for reforms in the previous and subsequent two years, include firm-level controls, as well as countryindustry dummies, country-year dummies and industry-year dummies. Standard errors are robust and clustered by country and industry. ${ }^{*},{ }^{* *},{ }^{* * *}$ refer to statistical significance levels of $10 \%, 5 \%$ and $1 \%$ respectively. Young, medium-aged and old firms are defined as being $0-9,10-25$ and $25+$ years old, respectively, in year $\mathrm{t}-1$. 
ECO/WKP(2016)35

Table A11. The short-term effects of product market reforms by industry and firm age

$\%$ change in the outcome variable of interest in years after a major reduction in entry barriers, selected coefficients

\begin{tabular}{|c|c|c|c|c|c|c|c|c|c|c|}
\hline & & \multicolumn{2}{|c|}{ Network industries } & \multicolumn{3}{|c|}{ Retail } & \multicolumn{4}{|c|}{ Professional senvices } \\
\hline & & $t=0$ & $t=1$ & $t=2$ & $t=0$ & $t=1$ & $t=2$ & $t=0$ & $t=1$ & $t=2$ \\
\hline \multicolumn{11}{|c|}{ Panel A. log employment (L) } \\
\hline (1a) & Base (young firms) & $\begin{array}{c}0.0070 \\
(0.0102)\end{array}$ & $\begin{array}{c}0.0173 \\
(0.0180)\end{array}$ & $\begin{array}{c}0.0416 \\
(0.0234) \\
*\end{array}$ & $\begin{array}{l}-0.0005 \\
(0.0036)\end{array}$ & $\begin{array}{c}0.0073 \\
(0.0076)\end{array}$ & $\begin{array}{c}0.0147 \\
(0.0100)\end{array}$ & $\begin{array}{l}-0.0205 \\
(0.0429)\end{array}$ & $\begin{array}{l}-0.0653 \\
(0.0497)\end{array}$ & $\begin{array}{l}-0.0679 \\
(0.0677)\end{array}$ \\
\hline (2a) & Medium-aged firms & $\begin{array}{c}-0.0148 \\
(0.0123)\end{array}$ & $\begin{array}{c}-0.0190 \\
(0.0171)\end{array}$ & $\begin{array}{c}-0.0441 \\
(0.0296)\end{array}$ & $\begin{array}{c}0.0022 \\
(0.0032)\end{array}$ & $\begin{array}{c}0.0043 \\
(0.0051)\end{array}$ & $\begin{array}{c}0.0071 \\
(0.0071)\end{array}$ & $\begin{array}{c}0.0521 \\
(0.0687)\end{array}$ & $\begin{array}{c}0.1017 \\
(0.0895)\end{array}$ & $\begin{array}{c}0.1259 \\
(0.1168)\end{array}$ \\
\hline \multirow[t]{3}{*}{ (3a) } & Old firms & $\begin{array}{c}0.0014 \\
(0.0077)\end{array}$ & $\begin{array}{l}-0.0068 \\
(0.0143)\end{array}$ & $\begin{array}{l}-0.0196 \\
(0.0204)\end{array}$ & $\begin{array}{c}0.0006 \\
(0.0027)\end{array}$ & $\begin{array}{l}-0.0018 \\
(0.0042)\end{array}$ & $\begin{array}{l}-0.0022 \\
(0.0050)\end{array}$ & $\begin{array}{l}-0.0097 \\
(0.0686)\end{array}$ & $\begin{array}{c}0.1142 \\
(0.0688)\end{array}$ & $\begin{array}{c}0.1502 \\
(0.0918)\end{array}$ \\
\hline & $\mathrm{N}$ & 163,797 & 163,797 & 163,797 & 515,852 & 515,852 & 515,852 & 138,874 & 138,874 & 138,874 \\
\hline & Panel B. log capit & & & & & & & & & \\
\hline$(1 b)$ & Base (young firms) & $\begin{array}{c}0.0399 \\
(0.0121) \\
\star \star *\end{array}$ & $\begin{array}{c}0.0787 \\
(0.0191) \\
\star \star \star\end{array}$ & $\begin{array}{c}0.1105 \\
(0.0216) \\
\star \star \star\end{array}$ & $\begin{array}{c}0.0239 \\
(0.0115) \\
*\end{array}$ & $\begin{array}{c}0.0237 \\
(0.0174)\end{array}$ & $\begin{array}{c}0.0356 \\
(0.0175) \\
*\end{array}$ & $\begin{array}{c}0.1198 \\
(0.0410) \\
\star * *\end{array}$ & $\begin{array}{c}0.2570 \\
(0.0718) \\
\star \star \star \star\end{array}$ & $\begin{array}{c}0.3621 \\
(0.1050) \\
\star \star \star\end{array}$ \\
\hline$(2 b)$ & Medium-aged firms & $\begin{array}{c}-0.0290 \\
(0.0161) \\
*\end{array}$ & $\begin{array}{c}-0.0479 \\
(0.0275) \\
*\end{array}$ & $\begin{array}{c}-0.0752 \\
(0.0302) \\
* \star\end{array}$ & $\begin{array}{c}0.0096 \\
(0.0062)\end{array}$ & $\begin{array}{c}0.0275 \\
(0.0093) \\
\star \star \star\end{array}$ & $\begin{array}{c}0.0278 \\
(0.0162)\end{array}$ & $\begin{array}{l}-0.0419 \\
(0.1011)\end{array}$ & $\begin{array}{l}-0.2626 \\
(0.1582)\end{array}$ & $\begin{array}{c}-0.4442 \\
(0.1976) \\
\star \star\end{array}$ \\
\hline \multirow[t]{3}{*}{$(3 b)$} & Old firms & $\begin{array}{c}-0.0449 \\
(0.0218) \\
* \star\end{array}$ & $\begin{array}{c}-0.0791 \\
(0.0406) \\
\star\end{array}$ & $\begin{array}{l}-0.0719 \\
(0.0448)\end{array}$ & $\begin{array}{c}0.0054 \\
(0.0062)\end{array}$ & $\begin{array}{c}0.0116 \\
(0.0099)\end{array}$ & $\begin{array}{c}0.0032 \\
(0.0151)\end{array}$ & $\begin{array}{c}-0.2882 \\
(0.0654) \\
\star \star \star\end{array}$ & $\begin{array}{c}-0.5753 \\
(0.1741) \\
\star \star \star\end{array}$ & $\begin{array}{c}-0.7347 \\
(0.1899) \\
\star \star \star\end{array}$ \\
\hline & $\mathrm{N}$ & 130,828 & 130,828 & 130,828 & 388,596 & 388,596 & 388,596 & 112,226 & 112,226 & 112,226 \\
\hline & \multicolumn{10}{|c|}{ Panel C. log sales $(Y)$} \\
\hline$(1 c)$ & Base (young firms) & $\begin{array}{c}0.0348 \\
(0.0098) \\
* \star \star\end{array}$ & $\begin{array}{c}0.0583 \\
(0.0170) \\
* \star \star\end{array}$ & $\begin{array}{c}0.0577 \\
(0.0198) \\
* \star *\end{array}$ & $\begin{array}{c}0.0183 \\
(0.0117)\end{array}$ & $\begin{array}{c}0.0404 \\
(0.0193) \\
*\end{array}$ & $\begin{array}{c}0.0590 \\
(0.0333) \\
\star\end{array}$ & $\begin{array}{l}-0.0214 \\
(0.0790)\end{array}$ & $\begin{array}{c}-0.0301 \\
(0.1160)\end{array}$ & $\begin{array}{c}-0.0261 \\
(0.1688)\end{array}$ \\
\hline$(2 c)$ & Medium-aged firms & $\begin{array}{c}-0.0234 \\
(0.0109) \\
\star \star\end{array}$ & $\begin{array}{c}-0.0399 \\
\underset{* \star}{0.0175)}\end{array}$ & $\begin{array}{c}-0.0501 \\
(0.0239) \\
\star \star\end{array}$ & $\begin{array}{l}-0.0101 \\
(0.0170)\end{array}$ & $\begin{array}{l}-0.0115 \\
(0.0154)\end{array}$ & $\begin{array}{l}-0.0107 \\
(0.0193)\end{array}$ & $\begin{array}{c}0.0470 \\
(0.1348)\end{array}$ & $\begin{array}{c}0.1250 \\
(0.1877)\end{array}$ & $\begin{array}{c}0.2229 \\
(0.2723)\end{array}$ \\
\hline$(3 c)$ & Old firms & $\begin{array}{l}-0.0160 \\
(0.0106)\end{array}$ & $\begin{array}{c}-0.0371 \\
(0.0194) \\
\star\end{array}$ & $\begin{array}{c}-0.0466 \\
(0.0274) \\
*\end{array}$ & $\begin{array}{l}-0.0129 \\
(0.0128)\end{array}$ & $\begin{array}{l}-0.0238 \\
(0.0144)\end{array}$ & $\begin{array}{l}-0.0230 \\
(0.0173)\end{array}$ & $\begin{array}{c}0.0216 \\
(0.1191)\end{array}$ & $\begin{array}{c}0.0565 \\
(0.1895)\end{array}$ & $\begin{array}{c}0.0721 \\
(0.2719)\end{array}$ \\
\hline & $\mathrm{N}$ & 163,797 & 163,797 & 163,797 & 515,852 & 515,852 & 515,852 & 138,874 & 138,874 & 138,874 \\
\hline
\end{tabular}

Note: Regressions control for reforms in the previous and subsequent two years, include firm-level controls, as well as countryindustry dummies, country-year dummies and industry-year dummies. Standard errors are robust and clustered by country and industry. ${ }^{*},{ }^{* *},{ }^{* * *}$ refer to statistical significance levels of $10 \%, 5 \%$ and $1 \%$ respectively. Young, medium-aged and old firms are defined as being $0-9,10-25$ and $25+$ years old, respectively, in year $\mathrm{t}-1$. 


\section{REFERENCES}

Alesina, A., S. Ardagna, G. Nicoletti and F. Schiantarelli, 2005, "Regulation and Investment," Journal of the European Economic Association, Vol. 3, No 4, pp. 791-825.

Arnold, J., N. Giuseppe and S. Scarpetta, 2011, "Does Anti-Competitive Regulation Matter for Productivity? Evidence from European Firms," IZA Discussion Papers 5511, Institute for the Study of Labour (IZA).

Arnold, J.M., Javorcik, B., Lipscomb, M., and A. Mattoo, 2011, "Does Service Liberalization Benefit Manufacturing Firms? Evidence from the Czech Republic," Journal of International Economics, Vol. 85, No. 1, pp. 136-46.

Arnold, J.M., Javorcik, B., Lipscomb, M., and A. Mattoo, 2015, "Services Reform and Manufacturing Performance: Evidence from India," The Economic Journal, Vol. 126, No. 590.

Auerbach, A. and Y. Gorodnichenko, 2012, "Measuring the Output Responses to Fiscal Policy." American Economic Journal: Economic Policy, 4 (2): 1-27.

Baily, M. N., E. J. Bartelsman and J. Haltiwanger, 2001, "Labour Productivity: Structural Change And Cyclical Dynamics," The Review of Economics and Statistics, MIT Press, vol. 83(3), pages 420433, August.

Barone, G. and F. Cingano, 2011, "Service Regulation and Growth: Evidence from OECD Countries," The Economic Journal, Vol. 121, No. 555.

Bassanini, A., 2016, A bitter medicine? Short-term employment impact if deregulation in network industries", forthcoming OECD Social, Employment and Migration Working Papers Social, employment and migration working .

Bems, Rudolfs, Robert C. Johnson, and Kei-Mu Yi, 2011, "Vertical Linkages and the Collapse of Global Trade." American Economic Review, 101(3): 308-12.

Bertrand, M. and F. Kramarz, 2002, "Does entry regulation hinder job creation? Evidence from the French retail industry", Quarterly Journal of Economics, Vol. 117, No. 4, pp. 1369-1413.

Blanchard, Olivier and Francesco Giavazzi, 2003, "Macroeconomic Effects of Regulation and Deregulation in Goods and Labour Markets." Quarterly Journal of Economics 118 (3): 879-907.

Boeri, T., P. Cahuc and A. Zylberberg, 2015, "The Costs of Flexibility-Enhancing Structural Reforms: A Literature Review”, OECD Economics Department Working Papers, No. 1227.

Bordon, A-R., C. Ebeke and K. Shirono, 2016, "When Do Structural Reforms Work? On the Role of the Business Cycle and Macroeconomic Policies", IMF Working Paper, forthcoming.

Bouis, R., O. Causa, L. Demmou and R. Duval, 2012, "How quickly does structural reform pay off? An empirical analysis of the short-term effects of unemployment benefit reform", IZA Journal of Labour Policy, December, Vol. 1, No. 12. 
Bouis, R., R. Duval and J. Eugster, 2016, "Product Market Deregulation and Growth: New Industry-Level Evidence", IMF Working Paper, forthcoming.

Bourlès, R., G. Cette, J. Lopez, J. Mairesse and G. Nicoletti, 2013, "Do Product Market Regulations In Upstream Sectors Curb Productivity Growth? Panel Data Evidence for OECD Countries," The Review of Economics and Statistics, Vol. 95, No 5, pp. 1750-1768.

Cacciatore M. and G. Fiori, 2016, "The Macroeconomic Effects of Goods and Labour Markets Deregulation", Review of Economic Dynamics, Vol. 20, pp. 1-24, April.

Cacciatore, M., R. Duval, G. Fiori and F. Ghironi, 2016a, "Market Reforms in the Time of Imbalance." Journal of Economic Dynamics and Control, forthcoming.

Cacciatore, M., R. Duval, G. Fiori, and F. Ghironi, 2016b, "Short-Term Pain for Long-Term Gain? Market Deregulation and Monetary Policy in Small Open Economies", Journal of International Money and Finance, forthcoming.

Cacciatore, Matteo, Romain Duval, Giuseppe Fiori and Fabio Ghironi. Forthcoming. "Product and Labour Market Reforms at the Zero Lower Bound.” IMF Working Paper, International Monetary Fund, Washington.

Conway, P. and G. Nicoletti, 2006, "Product Market Regulation in the Non-Manufacturing Sectors of OECD Countries: Measurement and Highlights", OECD Economics Department Working Papers, No. 530, OECD Publishing, Paris.

Criscuolo, C. P. N. Gal and C. Menon, 2014, "The Dynamics of Employment Growth: New Evidence from 18 Countries," OECD Science, Technology and Industry Policy Papers 14, OECD Publishing.

Dabla-Norris, E., S. Guo, V. Haksar, M. Kim, K. Kochhar, K. Wiseman, and A. Zdzienicka, 2015, "The New Normal: A Sector-Level Perspective on Productivity Trends in Advanced Economies, IMF Staff Discussion Note, March 2015.

Decker, R.A., J. Haltiwanger, R. S. Jarmin and J. Miranda, 2015, "Where Has All The Skewness Gone? The Decline In High-Growth (Young) Firms In The U.S," NBER Working Papers 21776, National Bureau of Economic Research, Inc.

Duval, R., D. Furceri, J. Jalles, and H. Nguyen, 2016a, “A New Narrative Database of Product and Labour Market Reforms in Advanced Economies." IMF Working Paper, forthcoming.

Duval, R., D. Furceri, and J. Miethe, 2016b, "Breaking the Deadlock: Identifying the Political Economy Drivers of Structural Reforms.” IMF Working Paper, forthcoming.

Eaton, J., S, Kortum, B. Neiman and J. Romalis, 2011, “Trade and the Global Recession”, NBER Working Paper No. 16666, January 2011.

Egert, B. and P. Gal (2016), “The quantification of structural reforms: a new framework”, OECD Economics Department Working Paper, forthcoming (ECO/CPE/WP1(2016)7)

Fabrizio, K., N. Rose and C. Wolfram, 2007, "Do Markets Reduce Costs? Assessing the Impact of Regulatory Restructuring on US Electric Generation Efficiency”, American Economic Review, Vol. 97, No. 4, pp. 1250-1277. 
Foster, L., J. Haltiwanger and C. Syverson ,2008, "Reallocation, Firm Turnover, and Efficiency: Selection on Productivity or Profitability?" American Economic Review, 98(1): 394-425.”

Gal, P. N., 2013, "Measuring Total Factor Productivity at the Firm Level using OECD-Orbis," OECD Economics Department Working Papers 1049, OECD Publishing.

Gilhooly, B., 2009, "Firm-level estimates of capital stock and productivity", Economic \& Labour Market Review, Vol 3, No 5, May 2009.

Giroud, X. and H. Mueller, 2015, "Firm Leverage and Unemployment during the Great Recession",

Gorodnichenko, Y., J. Svejnar and K. Terrell, 2016, "When does FDI have positive spillovers? Evidence from 17 emerging market economies," Journal of Comparative Economics, 42(2014), 954-969.

Goolsbee, A. and C. Syverson, 2008, "How do incumbents respond to the threat of entry? Evidence from the major airlines", Quarterly Journal of Economics, Vol. 123, No. 4, pp. 1611-1633.

IMF, 2015, World Economic Outlook, Chapter 3, April, International Monetary Fund, Washington, D.C.

IMF, 2016, World Economic Outlook, Chapter 3, April, International Monetary Fund, Washington, D.C.

Inklaar, R. and M. P. Timmer, 2014, "The Relative Price of Services" Review of Income and Wealth 60 (4): 727-746

Jorda, O., 2005, "Estimation and Inference of Impulse Responses by Local Projections," American Economic Review, Vol. 95(1), pages 161-182, March.

Kalemli-Ozcan, S., B. Sorensen, C. Villegas-Sanchez, V. Volosovych and S. Yesiltas, 2015, "How to Construct Nationally Representative Firm Level data from the Orbis Global Database," NBER Working Papers 21558, National Bureau of Economic Research, Inc.

Kalemli-Ozcan, S., L. Laeven and D. Moreno, 2015, "Debt overhang, rollover risk and investment in Europe", mimeo.

Koske, I., I. Wanner, R. Bitetti and O. Barbiero, 2015, "The 2013 update of the OECD's database on product market regulation: Policy insights for OECD and non-OECD countries", OECD Economics Department Working Papers, No. 1200, OECD Publishing.

Nicoletti, G. and S. Scarpetta, 2005, "Regulation and Economic Performance: Product Market Reforms and Productivity in the OECD," OECD Economics Department Working Papers 460, OECD Publishing.

Lanau, S. and P. Topalova (2016), "The Impact of Product Market Reforms on Firm Productivity in Italy", IMF Working Paper, forthcoming.

OECD, 2015a, The Future of Productivity, Organization for Economic Cooperation and Development, Paris.

OECD, 2015b, Economic Policy Reforms: Going for Growth, Organization for Economic Cooperation and Development, Paris.

OECD, 2016a, Economic Policy Reforms: Going for Growth, Organization for Economic Cooperation and Development, Paris. 
OECD, 2016b, OECD Employment Outlook, Chapter 3, "Short-term Effects of Structural Reforms: Pain Before the Gain?", Organization for Economic Cooperation and Development, Paris, forthcoming.

Rajan, R. and L. Zingales, 1998, "Financial Dependence and Growth", American Economic Review, Vol. 88, No. , pp. 559-586.

Ribeiro, P. S., S. Menghinello and K. De Backer, 2010, "The OECD Orbis Database: Responding to the Need for Firm-Level Micro-Data in the OECD", OECD Statistics Working Papers, No. 2010/01, OECD Publishing, Paris.

Schivardi, F. and E. Viviano, 2011, "Entry Barriers in Retail Trade", Economic Journal, Vol. 121(551), pages 145-170, March.

Teulings, C. and N. Zubanov, 2014, "Is Economic Recovery a Myth? Robust Estimation of Impulse Responses", Journal of Applied Econometrics, Vol. 29, pp. 497-514.

Timmer, M. P., Dietzenbacher, E., Los, B., Stehrer, R. and de Vries, G. J., 2015,

"An Illustrated User Guide to the World Input-Output Database: the Case of Global Automotive Production", Review of International Economics, 23: 575-605

Wooldridge, J. M., 2009,“'On estimating firm-level production functions using proxy variables to control for unobservables," Economics Letters, Vol. 104. 